.

\title{
Economics of
}

\section{National Waste Terminal Storage}

\section{Spent Fuel Pricing Study}

(TRW 97158-E001-RU-00)

Prepared for

The Office of Waste Isolation

Union Carbide Nuclear Division

Oak Ridge, Tennessee 37830

May 1978

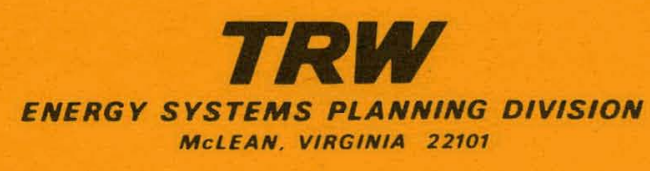




\section{DISCLAIMER}

This report was prepared as an account of work sponsored by an agency of the United States Government. Neither the United States Government nor any agency Thereof, nor any of their employees, makes any warranty, express or implied, or assumes any legal liability or responsibility for the accuracy, completeness, or usefulness of any information, apparatus, product, or process disclosed, or represents that its use would not infringe privately owned rights. Reference herein to any specific commercial product, process, or service by trade name, trademark, manufacturer, or otherwise does not necessarily constitute or imply its endorsement, recommendation, or favoring by the United States Government or any agency thereof. The views and opinions of authors expressed herein do not necessarily state or reflect those of the United States Government or any agency thereof. 


\section{DISCLAIMER}

Portions of this document may be illegible in electronic image products. Images are produced from the best available original document. 


\section{NOTICE}

This report was prepared as an account of work sponsored by the United States Government. Neither the United States nor the Department of Energy, nor any of their employees, nor any of their contractors, subcontractors, or their employees, makes any warranty, express or implied, or assumes any legal 1iability or responsibility for the accuracy, completeness or usefulness of any information, apparatus, product or process disclosed, or represents that its use would not infringe privately owned rights. 


\section{Economics of}

\section{National Waste Terminal Storage}

\section{Spent Fuel Pricing Study}

This report was prepared by TRW Energy Systems under subcontract 86Y-42512 with Union Carbide Corporation, Nuclear Division, under contract W-7405-eng 26 with the Department of Energy. The subcontract was administered by the Office of Waste Isolation, Union Carbide Corporation, Nuclear Division. 


\section{SUMMARY}

In this report the methodology for equitably pricing commercial nuclear spent fuel management is developed, and the results of four sample calculations are presented. The spent fuel management program analyzed in this study places encapsulated spent fuel in bedded salt while maintaining long-term retrievability. System design was intended to be reasonable but not optimum. When required, privately-owned Away From Reactor (AFR) storage is provided and the spent fuel placed in AFR storage is eventually transported to final storage. Applicable Research and Development and Government Overhead are included for completeness of cost recovery.

The cost of each component by year was estimated from the most recent applicable data source available. These costs were input to the pricing methodology to establish a one-time charge whose present value exactly recovered the present value of the expenditure flow. The four cases exercised were combinations of a high and a low quantity of spent fuel managed, with a single repository (venture) or a multiple repository (campaign) approach to system financial.structure. Each flow of spent fuel was carefully traced to assure that receiving, processing, and capacity constraints were not exceeded.

The price for spent fuel management calculated in this study ranged from 116 to 152 dollars (1978) per kilogram charged initially to the reactor. The effect of spent fuel receiving rate on price is illustrated by the fact that the extremes of price did not coincide with the cases having the extremes of undiscounted cost. These prices for spent fuel management are comparable in magnitude to other fuel cycle costs. The range of variation is small because of compensating effects, i.e., additional costs for high early deliveries (AFR and transportation) versus lower present value of future revenue for later delivery cases. The methoduluyy contains numerous conservative assumptions, provisions for contingencies, and covers the complete set of spent fuel management expenses. 


\section{ACKNOWLEDGEMENTS}

The National Waste Terminal Storage Spent Fuel Management Pricing Report was prepared by John D. Forster, Dr. Stanley Cohen, and Dr. S. David Hu of TRW Energy Syștems Planning Division. Overall study direction was provided by Dr. F. P. Mertes, Jr. Computer support was directed by L.M. Green. Invaluable guidance in both performing and documenting this study was provided by:

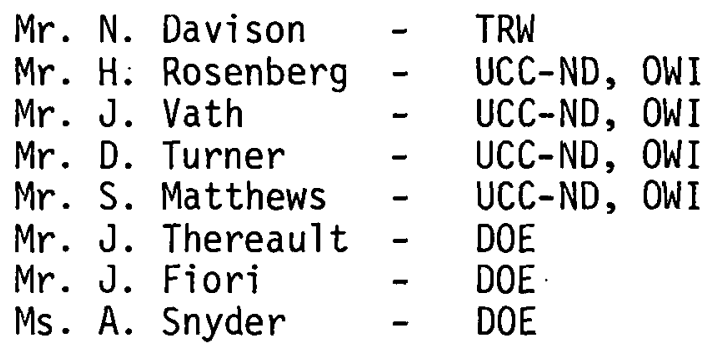

The authors, however, retain full responsibility for any errors. 
SUMMARY . . . . . . . . . . . . . . . . . . i

ACKNOWLEDGEMENTS. . . . . . . . . . . . . . . . .

LIST OF FIGURES . . . . . . . . . . . . . . . . iv

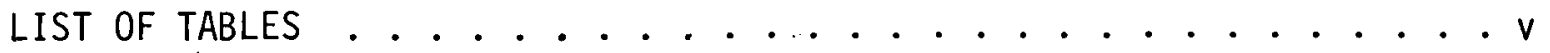

CHAPTER 1.0 INTRODUCTION . . . . . . . ........... . . . .

CHAPTER 2.0 SYSTEM DESCRIPTION ................ . . . . .

CHAPTER 3.0 GEOLOGIC REPOSITORY . . . . . . . . . . . . . . 3-1

CHAPTER 4.0 ENCAPSULATION FACILITY . . . . . . . . . . . . . 4-1

CHAPTER 5.0 AWAY FROM REACTOR STORAGE ............ . . 5-1

CHAPTER 6.0 TRANSPORTATION .................. . . . . . .

CHAPTER 7.0 RESEARCH AND DEVELOPMENT ............ . . . .

CHAPTER 8.0 GOVERNMENT OVERHEAD ................. . . . . . .

CHAPTER 9.0 SPENT FUEL QUANTITY . . . . . . . . . . . . . . 9-1

CHAPTER 10.0 SCENARIOS ..................... . . . . . . $10-1$

CHAPTER 11.0 PRICING METHODOLOGY ................... . . . . 11

CHAPTER 12.0 RESULTS . . . . . . . . . . . . . . . . 12-1

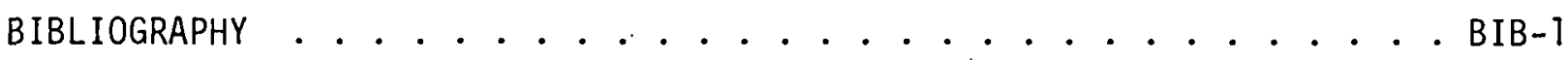

APPENDIX A DETAILED COST RESULTS . . . . . . . . . . . . A-1

APPENDIX B DETAILED PRICE RESULTS ................ . . . . . . . .

APPENDIX $C$ FORMULAS FOR COMPUTATION OF SPENT FUEL MANAGEMENT PRICE . . C- 1

APPENDIX D PROOF OF EQUIVALENCF OF CAPITAL RECOGNITION PROCEDURE TO INTEREST/DEPRECIATION PROCEDURE FOR GOVERNMENT

CAPITAL COSTS . . . . . . . . . . . . . . . D-1 


\section{LIST OF FIGURES}

FIGURE NO.

2-1

3-1

4-1

5-1

7-1

$12-1$

$12-2$

$12-3$

$12-4$
TITLE

PAGE NO.

Spent Fuel Management System Overview . . . . . . . 2-2

Variable Geologic Repository Annual Cost . . . . . 3-6

Encapsulation 0\&M Cost vs. Fuel Encapsulated . . . 4-7

AFR Capital Costs . . . . . . . . . . . . 5-3

Research and Development Cost . . . . . . . . 7-2

Cost Center Components of Price Results . . . . . . 12-3

Venture Methodology Cases . . . . . . . . . 12-4

Campaign Methodology Cases. . . . . . . . . . 12-5

Spent Fuel Management Cost Comparison . . . . . . . 12-8 


\section{LIST OF TABLES}

TABLE NO.

TITLE

PAGE NO.

3-1

3-2

3-3

3-4

4-1

4-2

4-3

4-4

4-5

4-6

5-1

5-2

6-1

8-1

9-1

9-2

$10-1$

$10-2$

10-3

$10-1$

$10-5$

11-1

$11-2$

12-1

$12-2$

$12-3$

$12-4$
Details of Bechtel Owner's Cost Methodology . . . . 3-2 Geologic Repository Operator's Startup Expenses . . . 3-3 Geologic Repository Capital Costs (1978 \$ M). . . . . . 3-4 Geologic Repository Decommissioning Costs . . . . . . 3-7 Encapsulation Capital Cost Scaling . . . . . . . 4-2 Encapsulation Facility Capital Costs by Year . . . . 4-3 Encapsulation Facility Staff Requirements . . . . . 4-4 Encapsulation Personnel Cost As A Function of Capacity Available ........... . 4-5 Encapsulation Materia ${ }^{2}$ Costs . . . . . . . 4-6 Encapsulation Decommissioning Costs . . . . . . 4-8 AFR Capital costs To The Operator . . . . . . . . 5-4 AFR Decommissioning Cost ......... . . 5-4 Transportation Summary ........... 6-3 Government Overhead Annual cost . . . . . . . . . 8-1 Nuclear Generating Capacity and Discharges...... . 9-3 Spent Fuel Handling Constraints . . . . . . . 9-4 Scenario Summary . . . . . . . . . . . 10-3

Spent Fuel Flow - Case 1, Five Year Delay, Venture Methodology .. . . . . . . . . 10-5

Spent Fuel Flow - Case 2, Five Year Delay, Campaign Methodology ... . . . . . 10-6

Spent Fuel Flow - Case 3, Ten Year Delay, Venture Methodology . . . . . . . . 10-7

Spent Fuel Flow - Case 4, Ten Year Delay, Campaign Methodology ......... 10-8 Spent Fuel Management Cost Centers ... . . . . . 11-2 Pricing Parameter Values . . . . . . . . . 11-11 Summary of Price Results . . . . . . . . 12-1 Life Cycle Cost Summary By Cost Center . . . . . . 12-6 Life Cycle Cost Summary By Category . . . . . . . 12-7 Spent Fuel Acceptance Cost Comparison . . . . . . 12-8 


\section{LIST OF TABLES (Continued)}

TABLE NO.

TITLE

PAGE NO.

A-1

Detailed Data Summary. . . . . . . . . A-2

$A-2$

Detailed Cost Inputs - Case 1........ A-3

A-3

Detailed Cost Inputs - Case 2..........A-4

A-4

Detailed Cost Inputs - Case 3 . . . . . . . A-5

A-5

Detailed Cost Input - Case 4 .......... A-6

A-6

Undiscounted Cost Matrix - Case 1 . . . . . A-7

$A-7$

Undiscounted Cost Matrix - Case 2 . . . . . . . A-7

A-8

Undiscounted Cost Matrix - Case 3 . . . . . . A-8

$A-9$

$A-10$

Undiscounted Cost Mntrix - Caze 1........ A-9

$B-1$

Contingency costs . . . . . . . . . . . A-10

$B-2$

Price Kesults in $\$ / \mathrm{Kg}$ U By Cost Center . . . . . B-2

$\mathrm{C}-1$

Price Results in Mills/Kilowatts-Hour ...... . B-2

$\mathrm{C}-2$

Variables . . . . . . . . . . . . . C-8

Parameters ................. C-10 


\subsection{INTRODUCTION}

\subsection{PURPOSE}

The recent Administration decision to defer reprocessing commercial spent nuclear fuel generates a national requirement for an alternative spent fuel management method for electric utilities. Numerous alternatives have been advanced involving various storage schemes. It.is assumed that basic options are familiar.

This study outlines the basic economic issues relating to one such al ternative, that of ultimate placement of spent fuel in bedded salt with long-term retrievability. The purpose of this study is to provide an equitable commercial spent fuel management pricing procedure for future use, and to exercise this procedure in four cases of interest to generate illustrative prices for spent fuel management.

Three principal ground rules have been adhered to in this study. First, equitable pricing has been defined as that price which leads to a revenue cash flow the present value of which exactly recovers the present value of all associated costs. This is consistent with the legislative requirement to recover all costs and is interpreted to include al1 research and development, government overhead and post operational activities attributable to commercial spent nuclear fuel management as well as direct program costs.

The second principal ground rule is that the price developed be a one-time charge with no retroactive adjustments for flow or cost estimation changes. Adjustments will be necessary, however, and since the future customers will generally be the same as existing customers, little inequity can arise from this ground rule.

Finally, this study takes no credit for the uranium or plutonium content of the accepted spent fuel. This ground rule is consistent with the current policy of indefinite deferral of reprocessing.

\subsection{BACKGROUND}

This task began with the award by the Office of Waste Isolation (OWI) of a contract to the TRW Energy Systems Planning Division to develop, program, and exercise a spent fuel storage cost model. 
Subsequently, DOE formally announced its plans to accept spent fuel in return for a one-time charge after a five-year notification period. The methodology and procedures for calculating the one-time charge were to be published in the Federal Register along with an initially proposed price for comments from all interested parties.

In view of this announcement, OWI added three tasks to the TRW contract to collect additional data and develop the methodology required to calculate four cases of one-time charges for spent fuel management. The system design for these cases was to be reasonable, but no attempt was to be made to optimize all variables. The scope was limited in time and other resources in order to provide timely response. This study is the output of these additional task.s.

\subsection{REPORT OUTLINE}

This report begins with an overview of the total system (Chapter 2) and a description of the assumptions and data sources of each cost center for which costs are included (Chapters 3-8). Following this, the spent fuel flow and scenario assumptions are enumerated in Chapters 9 and 10 . The pricing methodology combining the input data to form results is contained in Chapter 11 and the results are presented and interpreted in Chapter 12. Detailed cost, price, and methodolngy data are reserved for the Appendices. 


\subsection{SYSTEM DESCRIPTION}

This chapter describes, in general, the system to which the ground rules enumerated in the Introduction were applied to yield scenarios for calculation of a one-time charge for storage and disposal of spent fuel. It provides a concise overview of the study interrelationships and boundaries. More detail on each system component, including numerical values which were assumed, will be found in the chapters which follow.

\subsection{SYSTEM OVERVIEW}

The spent fuel management system used in this study was broken down into six convenient collection categories called cost centers. The interrelation of these cost centers is illustrated in Figure 2-1. Spent fuel from commercial reactors is accepted FOB at the applicable first system component (AFR or geologic repository) at a rate determined by the scenario being studied (Chapter 10). Encapsulated retrievable spent fuel will be placed in bedded salt at the geologic repository beginning in late 1985. Spent fuel is placed at its design rate, or at the rate at which spent fuel is received from both U.S. and foreign sources if no other source exists. Annual spent fuel acceptance rate is increased to the design rate by accepting the existing backlog (2270 MTU in 1976) of spent fuel or by accepting spent fuel previously placed in AFR storage when these sources are available. Transportation of spent fuel from the AFR to the repository is included as a cost center. Finally, research and development and government overhead are included for technical and managerial completeness.

The AFR, encapsulation, and geologic repository cost centers are facility oriented. They contain costs in each of the expenditure categories, capital, operations and maintenance, and trust funds. The transportation, research and development, and government overhead cost centers are service oriented. They contain costs for their services categorized as "Other", for separability from those of the facility cost centers. All these costs with their related spent fuel flows will be found in detail in Appendix A. 


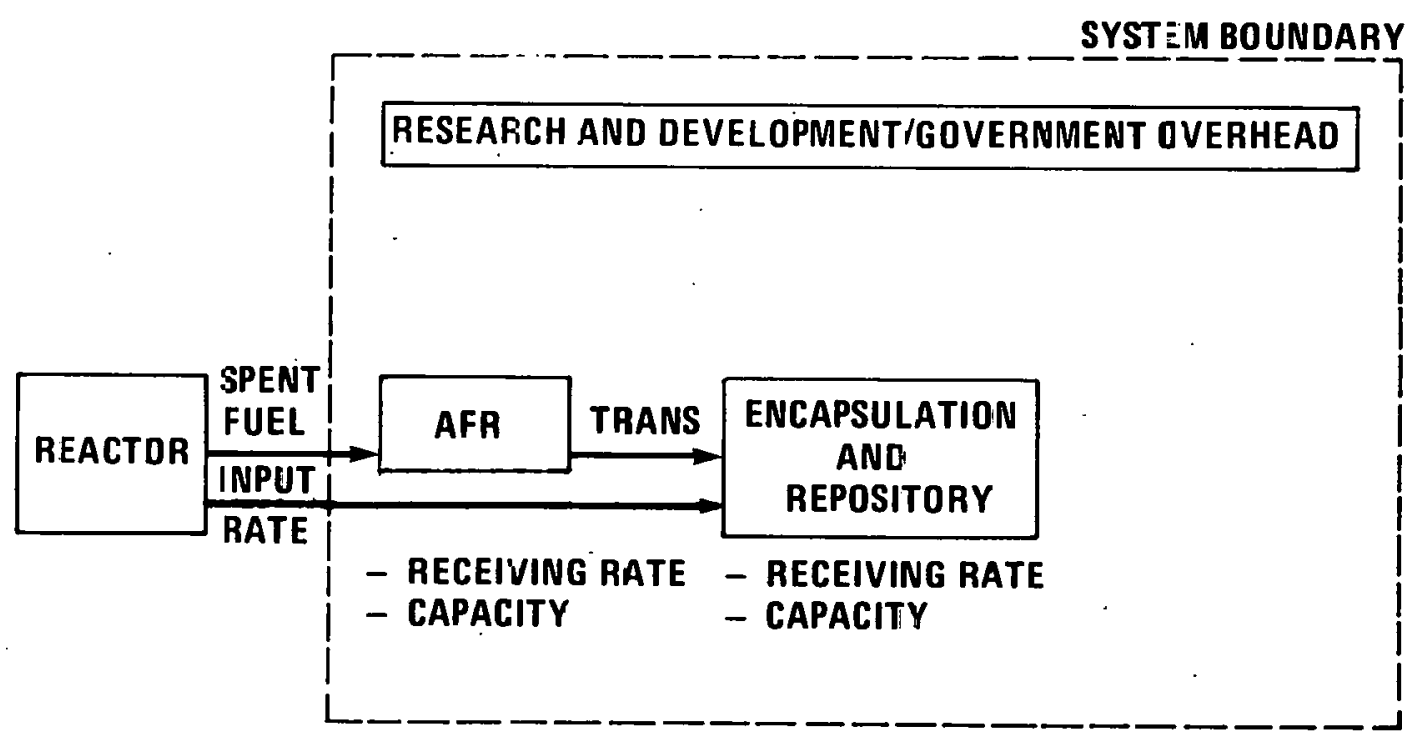

4 SCENAIRIOS

- FUJEL INPUT RATE

- FINANCIAL STRUCTURE

Figure 2-1. Spent FuEl Management System Overview 


\subsection{CONSTRAINTS}

The AFR, encapsulation facility, and geologic repository all have receiving or processing rate constraints expressed in annual metric tons of uranium. The AFR and geologic repository also have total capacity constraints. The numerical values of these constraints will be found in Chapter 9. All detailed flow quantities have been carefully examined to assure that these constraints have not been violated.

Geologic repository total capacity has the additional characteristic of varying with the age of the fuel emplaced in it. This variation has been accounted for by using data from reference III-3 in the capacities of each case. Furthermore, geologic repository receiving rate constraint has a five-year initial value for phase-in which triples to its maximum value for all subsequent (to capacity) years.

Second encapsulation and second geologic repository facilities have higher constraints than the first facilities; however, no capital cost increase has been added. This is equivalent to assuming some savings due to learning effects in facility construction. The validity of this assumption is uncertain, but it is the most reasonable assumption available based on present expectations.

Rate constraints have delayed completion of backlog acceptance and increased AFR capacity requirements. Capacity constraints require determining the number and utilization of AFR storage facilities and the timing of second repository construction. In each case, second repository timing has been carefully examined not only for flow constraints, but also for the effect on first repository closing which was delayed in both multirepository cases because of the acceptance of part of the flow by the second repository.

\subsection{SCENARIO}

The spent fuel management system described above was exercised with four scenarios representing all combinations of two fuel input rates, and two approaches to the financial structure of the price. For illustration, cooling delays of five and ten years from the discharges in reference IX-1 were used as high and low baselines to which were added existing backlog and 10 percent of candidate foreign fuel. Yearly breakdowns of these flows will be found in Chapter 10. 
The first approach to financial structure was to treat all elements relating to the first repository only through its closing. This approach, called venture methodology, minimizes required assumptions and creates the approach most firmly based in current data. The second approach selected was to treat a11 required elements until a fixed year in the future (2000 for this study). The approach, called the campaign methodology, could be used on a continuing basis to price spent fuel management in the future by changing the year of termination. This methodology requires assumptions about second repository and related activities, and a treatment of partially used facilities at termination. The two methodologies provide unique insights; therefore, both were exercised to provide results of greatest interest.

\subsection{TRUST FUNDS}

Al1 decommissioning and post operational activities in the price calculations of this study were included through trust funds present valued into the last year of the applicable facility operation or the termination year for partially used facilities. The AFR, encapsulation, and geologic repository cost centers are each assigned their own decommissioning trust fund, but only the geologic repository cost center was provided a post operation trust fund. Thus, there were four types of trust funds.

The cost distribution by year for each decommissioning trust fund is provided in the applicable facility's chapter of this report as is its present value which can be seen in the cost data in Appendix A.

The post operation trust fund has two purposes. First, it supports maintenance operations after the facility reaches capacity but before decommissioning. Second, it provides contingency funds for possible activities after decommissioning which remain undefined at the time of this study. It is assumed that the former purpose will be the most financially demanding and, therefore, will serve to determine the size of the trust fund. A detailed analysis of required post operational activities is beyond the scope of this study. 
Partially used facilities in the termination year require partial trust funds to assure equitable cost distribution to each user. For this purpose, the full trust funds described above and enumerated in the facility chapters were first reduced by the unutilized fraction of the facility (i.e., multiplied by the fraction of capacity filled). They were then discounted from the closing year of the facility (after the termination year) to the termination year of the scenario. The resulting values can be seen in the cost details of Cases 2 and 4 in Appendix A. 


\subsection{GEOLOGIC REPOSITORY}

This chapter enumerates the assumptions, data sources, and methodologies used to determine the costs of the geologic repository. There are four categories of costs used for each repository:

- Capital costs

- Operations and maintenance (O\&M) costs

- Decommissioning costs

- Post operational costs.

Each category of costs for each repository is displayed in detail in Appendix A.

\section{$3.1 \cdot$ ASSUMPTIONS}

This study assumes that the geologic repository is to be located in underground bedded salt deposits and will encompass 2000 acres. The facility will accept spent fuel beginning in late 1985 at an initial design rate of 6000 fuel assemblies (1780 MTU) per year. After receiving spent fuel at this rate for 5 years, the rate will triple to 18,000 fuel assemblies (5320 MTU) per year. This study was conducted with the design rate as maximum spent fuel input to the repository. Each repository will provide the facilities and supporting utilities for mining, storing, and backfilling the salt; ventilating all shafts and tunnels; receiving spent fuel either by truck or rail; the emplacement of the canistered fuel in salt while maintaining the retrievability.

The repository is assumed to be in substantial conformance with the Generic Envircnmental Impact Statement on Commercial Waste Management. However, specifics of this statement have not been released for public dissemination at the time of this study. Where necessary for display, details were drawn from reference III-l.

The capacity of the repository is determined by the mode of operation. and the age of the fuel being emplaced. Each first repository will be operated in a long-term retrievable mode. Capacity in this mode of operation is determined from room: closure limits. Second repositories, 
operating in the five-year retrievability mode, are limited by total heat energy delivered to the salt. Assuming ten-year-old spent fuel is emplaced in the second repository operating in this mode, the capacity is 104,700 MTU. Fuel limits for the first repository are 44,200 MTU for five-year-old fuel (reference III-2) and 52,500 MTU for ten-year-old fuel (reference III-3). Emplacement of these capacities of fuel results in equivalent heat energy delivered to the salt over a 25 -year period.

\subsection{DATA SOURCES}

The basic source of geologic repository capital, 0\&M, and decommissioning expenditures is Mr. C. D. Zerby!s letter of January 6, 1978 entitled "Spent Fuel Repository Cost Estimates" (reference. III-4). The letter details the costs for operating in both five-year and 25-year retrievability modes. These costs include an undesignated capital contingency factor of 22 percent. Since the current study is of indefinite retrievability, the 25 -year retrievability case was used as the baseline.

To obtain complete consistent costs for this study, capital costs from $\mathrm{Mr}$. Zerby's letter were modified in two ways. First, these costs were increased by 10.2 percent to account for owner's cost. This factor of 10.2 percent was derived from the non-reactor owner's cost calculation used by Bechtel. (see references III-5, IV-1, IV-2, and V-3). For explicit details of these factors, see Table 3-1.

TABLE 3-1.

Details of Bechtel Owner's Cost Methodology (Non-Reactor Nuclear Facilities)

\begin{tabular}{|l|c|}
\hline CATEGORY & FACTOR \\
\hline Land & $1.8 \%$ \\
Equip.Spares & $0.6 \%$ \\
Permits and Licenses & $1.2 \%$ \\
Interest During Construction & $18.0 \%$ \\
Startups & $0.9 \%$ \\
Initial Inventories & $0.9 \%$ \\
Eng. Ops. \& Accounting & $2.4 \%$ \\
Manuals, Clothing \& Stock & $3.0 \%$ \\
Insurance & $1.2 \%$ \\
\hline
\end{tabular}


When interest during construction and land costs were excluded from geologic repository costs, the remainder was 10.2 percent. These exclusions were required in the computations because the former duplicates the present value calculation and the latter is specifically estimated within the capital costs cited in reference III-4. These owner's costs were distributed by year in proportion to the other capital costs detailed by the letter.

The second modification to reference III-4 capital costs was the inclusion of operator startup expense. These costs, including their distribution by year, were provided by OWI and are enumerated in Table 3-2.

TABLE 3-2.

Geologic Repository Operator's Startup Expenses

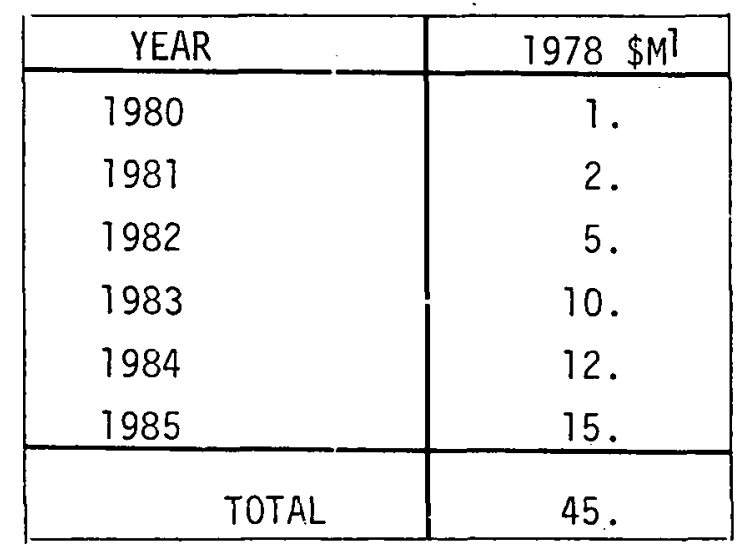

The two modifications, which total \$96.M, (1978) form the "Administration costs" category in Table 3-3. This table details the total geologic repository capital costs. No additional contingency was provided due to these cost increases.

One modification to reference III-4, 25-year retrievability operations and maintenance costs, has been made for this study. The costs for excavation have been stretched from three to seven years as used in the five-year retrievability case. The change reflects only the conservative use of underground mining equipment and does not impact the emplacement rate of spent fuel. This modification results in no change in the total undiscounted costs. However, the expenses for the first three years show an approximate reduction of 10 percent while an increase of approximately 7 percent is shown over the next four years.

$\overline{T_{\text {For computational }}}$ simplicity, 4 th quarter 1977 dollars were assumed equal to 1978 dollars. 
Table 3-3. Geologic Repository Capital Costs (1978 \$M)

\begin{tabular}{|c|c|c|c|c|c|c|c|c|c|c|}
\hline & CATEGCRYT & TOTAL & 78 & 79 & 80 & 81 & 82 & 83 & 84 & 85 \\
\hline 1.0 .0 & PLANT AND CAPITAL EQUIP. & & & & & & & & & \\
\hline 1.1 .0 & ADMINISTRATION COSTS 2 & 96.0 & .03 & .25 & 3.01 & 10.22 & 18.13 & 21.37 & 20.60 & 22.39 \\
\hline 1.2 .0 & LINE ITEM CONSTRUCTION & & & & & & & & & \\
\hline 1.2 .1 & ENG. DESIGN AND IHSPECTION & 54.34 & & .98 & 8.53 & 20.4: & 12.70 & 4.62 & 3.65 & 3.45 \\
\hline 1.2 .2 & LAND AND LAND RIGGTS & 11.25 & .26 & 1.0 & 7.5 & 2.49 & & & & \\
\hline p.2.3.0 & BASIC CONSTRUCTION COSTS & & & & & & & & & \\
\hline 1.2 .3 .1 & IMPROVEMENTS TO LAND & 30.865 & & & & 13.071 & 15.374 & 2.42 & & \\
\hline 1.2 .3 .2 & BUILDIMGS & 21.845 & & & & 1.367 & 6.653 & 2.833 & 6.366 & 4.686 \\
\hline 1.2.3.3 & OTHER STRUCTURES & c & & & & & & & & \\
\hline 1.2.3.4 & SPECIAL FACILITIES & 169.8 & & & & 9.43 & 36.608 & 53.296 & 36.947 & 33.469 \\
\hline 1.2 .3 .5 & UTILITIES & 46.48 & & & & 16.447 & 19.314 & 6.639 & 3.583 & .497 \\
\hline 1.2 .4 & STANDARD EQUIPMENT & 72.93 & & & & 2.446 & 14.298 & 21.06 & 18.202 & 16.924 \\
\hline 1.2 .5 & REMOVA: LESS SALLAGE & 0 & & & & & & & & \\
\hline 1.2 .6 & CONTINAENCY ALLOWANCE & $92.4 \mathrm{c}$ & .06 & .45 & 3.64 & 14.9 & 23.82 & 20.62 & 15.60 & 13.40 \\
\hline & TOTAL 3 & 596.0 & .35 & 2.68 & 22.68 & 90.77 & 146.9 & 132.86 & 104.95 & 94.81 \\
\hline
\end{tabular}

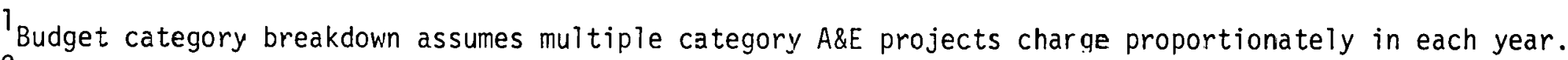
${ }^{2}$ No additional contingency allowance has been added to reference III- $S$ costs due to this expense.

${ }^{3}$ This cost data is shown in the detailed cost inputs of Appendix $A$ in $a^{-1} 1$ four cases. 
For years in which the full design receipt rate is emplaced in the repository, reference III-4 0\&M costs, modified as above, were used. For years in which an emplacement rate of less than that designed occurred, a more complex methodology was required. This low rate of emplacement occurred when the spent fuel receipt rates were below the design rate and there was no AFR content or backlog. For the years in which this lower rate occurred, the 0\&M costs for the repository were estimated in three parts.

- The time-related costs of capital equipment (surface and mining), mine excavation, and salt storage were assigned their value from reference III-4 by year from the repository opening.

- The rate-related annual costs of general mine support, waste handling, surface support, storage maintenance, equipment maintenance, personnel, utilities, and materials and supplies were estimated by manual interpolation of Figure 3-1 as a function of the annual received fuel. The figure illustrates a smooth curve through the four values individually estimated by OWI and documented in reference III- 6 .

- Retrievability sleeves and plugs costs were estimated at $\$ 7179$ per MTU for retrievable operations from reference III-4. All but the maximum rate phase of the second repository maintained long-term retrievability.

The complete set of 0\&M costs for the geologic repository is displayed in Appendix $A$.

Repository decommissioning costs were taken to be the last seven years of costs in reference III-4 for the 25-year retrievability case. 


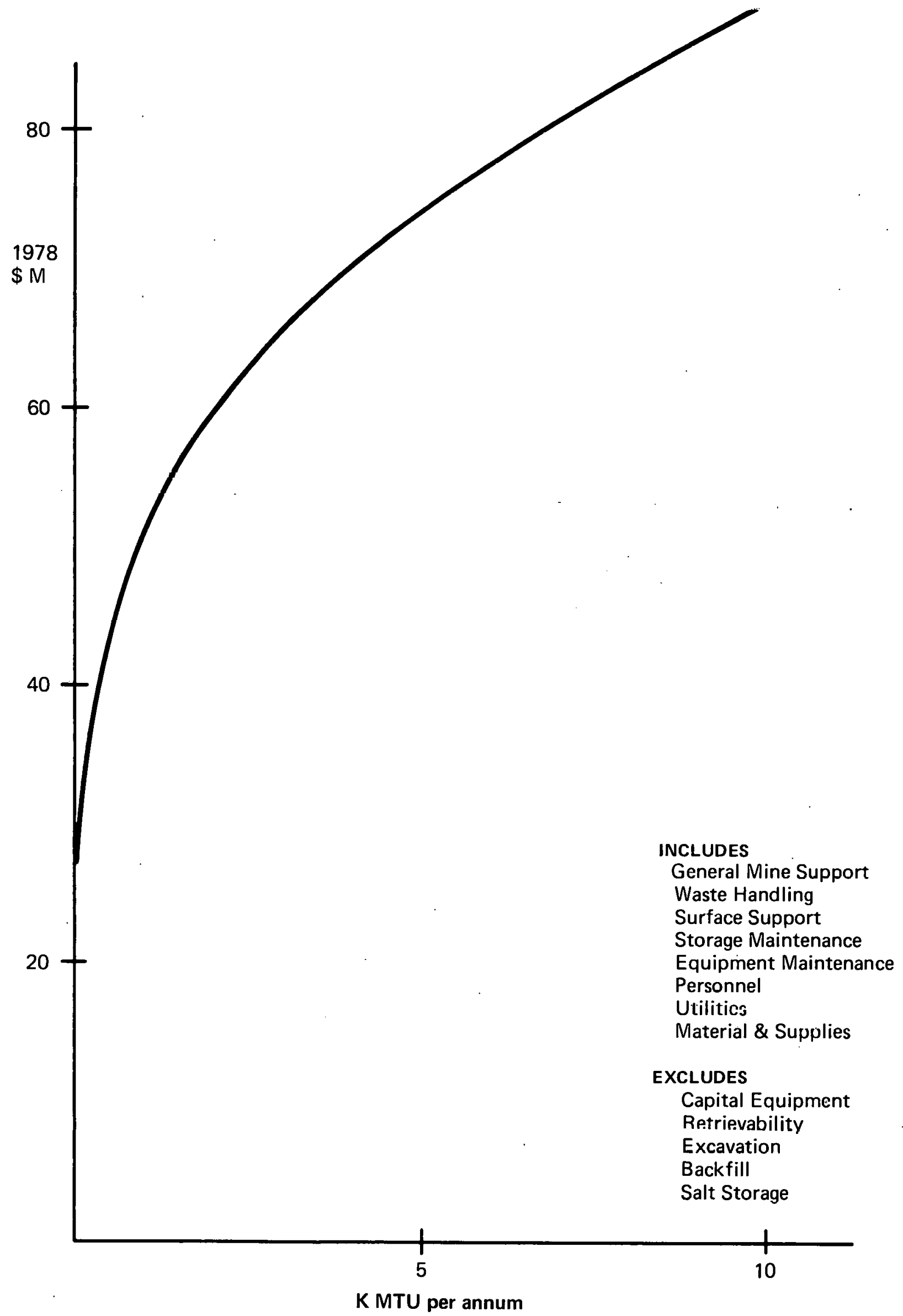

Figure 3-1. Variable Geologic Repository Annual Cost 3-6 
Table 3-4 enumerates these costs below.

TABLE 3-4.

Geologic Repository Decommissioning Costs

\begin{tabular}{|c|c|}
\hline Year & $1978 \$ M$ \\
\hline 1 & 34.615 \\
\hline 2 & 26.496 \\
\hline 3 & 26.373 \\
\hline 4 & 26.183 \\
\hline 5 & 35.790 \\
\hline 6 & 26.988 \\
\hline 7 & 21.596 \\
\hline TOTAL & 198.041 \\
\hline
\end{tabular}

These costs were discounted at 6.5 percent to the last year of operations (year 0 above), then charged to each closed repository. This discounting procedure results in $\$ 156.56 \mathrm{H}$. For partially filled repositories in the multirepository campaign methodology, this value is reduced by unutilized capacity fraction and discounted to the horizon year.

To support activities after final spent fuel emplacement, a post operational annuity has been provided. This annuity has been designed to produce exactly the average yearly expense shown during the 12 years of maintenance operations in reference III-4 when invested at 6.5 percent. It is assumed that these costs are the largest to be encountered; the annuity is conservatively estimated to produce the value of $\$ 24.78 \mathrm{M}$ (1978) yearly. Since the annuity is charged in the last year of operations but is not needed until the following year, it is discounted one year at a rate of 6.5 percent which resuits in $\$ 357.385 \%$ This value was also reduced by the unutiiized capacity fraction and discounted to the horizon year for partially used facilities in the multirepository campaign methodology case. After decommissioning, this trust fund is perpetually available to provide funds for any contingency relating to the repository. 


\subsection{ENCAPSULATION FACILITY}

This chapter contains the assumptions and data sources used to estimate capital, 0\&M, and decommissioning costs of the encapsulation cost center. The estimated costs for each case will be found in Appendix A.

\subsection{ASSUMPTIONS}

The encapsulation of spent fuel is assumed to take place at the geologic repository site. As the spent fuel is received, assemblies are placed in canisters which are then backfilled with sand, welded closed, tested for leaks and transported to temporary storage or to the canistered waste shaft of the geologic repository. This facility also has the ability to overpack failed fuel canisters with a second canister, and to weld, test, and transport these overpack canisters in a manner similar to standard canisters. The estimated annual capacity to encapsulate fuel is commensurate with the geologic repository receiving rate.

A water storage basin area is required to provide process surge capacity for encapsulation. A two-month processing surge capability is considered adequate for this purpose.

Fuel characteristics are assumed to allow two BWR fuel assemblies per canister, but only one PWR assembly per canister.

Finaliy, three percent of fuel arriving at the facility is assumed failed for estimating overpack requirements.

\subsection{DATA SOURCES}

Capital cost data for the encapsulation facility is based primarily on a scaling up of reference IV- 1 from 2000 MTU/year to 6000 MTU/year. Reference IV-l contains unspecified contingencies, which are assumed to be 22 percent for comparison. Costs in this reference also exclude receiving facilities and supporting utilities since the reference is on the site of a large storage basin. The referenced facility contains three hot cells for processing. One is reserved only for tailed fuel. Therefore, tripling capacity requires six cells for unfailed fuel and retaining the single cell for failed fuel for seven channels. Each category of cost in the referenced facility was scaled up using the ratio 
Table 4-1. Encapsulation Capital Cost Scaling

(2000 MTU/Year Increased to 6000 MTU/Year:

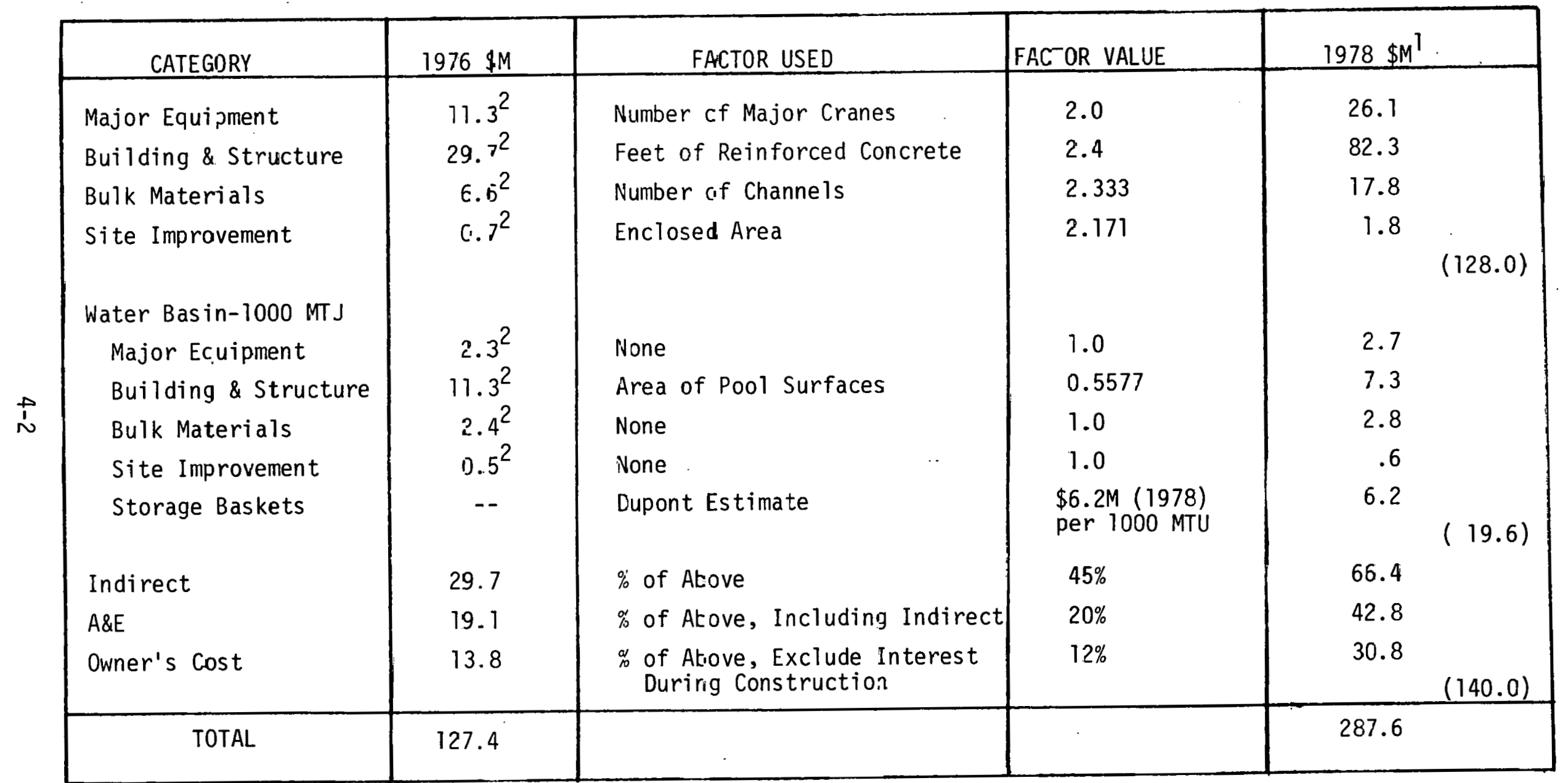

Inflated using the chemical industry plant capital cost index

${ }^{2}$ Unspecified contingency included. 
of a measurable appropriate architectural factor in the reference facility to the same factor in the enlarged facility. Water basin storage for two months' surge (1000 MTU) was estimated from reference IV-2 with the Building and Structures category scaled, but with other categories remaining as in the basic reference (2000 MTU). Storage baskets for this water basin were estimated using costs from reference $V-1$.

Table 4-1 lists the names and values of the factors used and the complete calculation of encapsulation facility capital costs. These costs were distributed by year using TRW's best judgment after examining in detail the construction schedule contained in reference IV- 1 and the schedule of the colocated geologic repository. Table 4-2 contains the resulting capital costs by year.

Table 4-2. Encapsulation Facility Capital Costs by Year 1978 \$ M

\begin{tabular}{|l|c|c|c|c|c|c|c|c|c|}
\hline & TOTAL & 78 & 79 & 80 & 81 & 82 & 83 & 84 & 85 \\
\hline ADMINISTRATION COST & 30.8 & & & & 3 & 5 & 8 & 10 & 4.8 \\
MAJOR EQUIP. & 26.1 & & & & & 8.2 & 12 & 5.9 & \\
BUILDINGS \& STRUCTURES & 82.3 & & & & 7 & 15 & 25 & 30.1 & 5.2 \\
BULK MATERIAL & 17.8 & & & & & 3 & 6 & 7.8 & 1 \\
SITE IMPROVEMENTS & 1.8 & & & & 0.6 & 0.5 & 0.4 & 0.3 & \\
INDIRECT & 66.4 & & & & 2 & 13 & 21 & 26 & 4.4 \\
A\&E & 42.8 & & & & 8 & 16 & 8 & 6 & 4.8 \\
WATER BASIN STORAGE & 19.6 & & & & & 5 & 7 & 6 & 1.6 \\
\hline \multicolumn{1}{|c|}{ TOTAL } & 287.6 & & & & 20.6 & 65.7 & 87.4 & 92.1 & 21.8 \\
\hline
\end{tabular}


Table 4-3. Encapsulation Facility Staff Requirements

\begin{tabular}{|c|c|c|}
\hline & FIRST SHIFT & EACH ADDITIONAL SHIFT \\
\hline \multicolumn{3}{|l|}{ OPERATORS } \\
\hline CELLS FOR UNFAILEU FUEL & 12 & 12 \\
\hline CELLS FOR FAILED FUEL & 3 & - \\
\hline HOLDING CELLS & 3 & 3 \\
\hline HANDLERS & 6 & 6 \\
\hline FOREMEN & 3 & 3 \\
\hline \multicolumn{3}{|l|}{ SUPPLY } \\
\hline GENERAL & 2 & 1 \\
\hline CONTAINERS & & \\
\hline FEED TO LINE & 3 & 1 \\
\hline REC. \& INSP. & 2 & - \\
\hline REPAIR & 1 & - \\
\hline FOREMEN & 1 & $m$ \\
\hline \multicolumn{3}{|l|}{ SHOP TECHNICIANS } \\
\hline WARM & 2 & - \\
\hline MECHANICAL & 3 & 1 \\
\hline ELECT. \& INST. & 3 & 1 \\
\hline SUPERVISOR & 1 & - \\
\hline \multicolumn{3}{|l|}{ MAINTENAIICE } \\
\hline JANITORIÁL & 4 & 1 \\
\hline UTILITIES & 2 & 2 \\
\hline PROCESS & 2 & 2 \\
\hline FOREMEN & 2 & 1 \\
\hline \multicolumn{3}{|l|}{ MISCELLANEOUS } \\
\hline GUARDS & 3 & 2 \\
\hline ACCOUNTING & 2 & 2 \\
\hline HEALTH PHYSICS & 2 & 2 \\
\hline CLERICAL & 3 & - \\
\hline SUPERVISORS & 4 & 1 \\
\hline ENGINEERS & 2 & - \\
\hline MAINAGEMENT & 3 & $!$ \\
\hline TOTAL & 74 & 42 \\
\hline
\end{tabular}


Encapsulation operating costs were estimated in two parts; first, personnel, and second, materials. Personnel costs were estimated by a detailed examination of the reference IV -1 facility resulting in the staff requirements enumerated in Table 4-3. Each shift shown in Table 4-3 is assumed able to operate two hot cells for unfailed fuel. All failed fuel operations are assumed to take place during the first shift since only 3 percent of capacity enters this cell. Shifts were assumed to be required in integer increments regardless of any excess capability this provided. Table 4-4 shows the personnel costs to encapsulate fuel as a function of capacity available that results from these assumptions. Table 4.4 Encapsulation Personnel Cost As A Function Of Capacity Available

\begin{tabular}{|c|c|c|}
\hline CAPACITY (MTU/YR) & PERSONNEL & COST $(1978$ \$ M) \\
\hline 2000 & 158 & 6.32 \\
2660 & 200 & 8.0 \\
3330 & 242 & 9.68 \\
4000 & 284 & 11.36 \\
4660 & 326 & 13.04 \\
5330 & 368 & 14.72 \\
6000 & 410 & 16.4 \\
\hline
\end{tabular}

For further conservatism, it is assumed that when required capacity is reduced, personnel will be retained if capacity later increases.

Material cost of the encapsulation cost center 0\&M expense was estimated based on the following unpublished data received from the OWI staff.

To $\$ 40,000$ per person--source DuPont, Savannah River Operations 
Table 4.5 Encapsulation Material Costs

(1978 \$)

\begin{tabular}{|l|l|}
\hline CANISTER & $\$ 400$ \\
TOP & $\$ 75$ \\
FREIGHT & $\$ 40$ \\
SAND/CANISTER & $\$ 2$ \\
OVERPACK & $\$ 600$ \\
OVERPACK TOP & $\$ 100$ \\
OVERPACK FREIGHT & $\$ 60$ \\
\hline
\end{tabular}

Combining these with the assumed fuel elements per canister, the ratio of types of fuel elements shown in reference III-3 and the 3 percent overpack rate results in an average cost per canister of $\$ 524$ or $\$ 1252$ per MTU.

Combining personnel and material costs, the 0\&M Cost of encapsulation as a function of encapsulated fuel is shown in Figure 4-1.

Decommissioning of the encapsulation facility is assumed to cost 10 percent of the total capital cost of the facility. This factor is commensurate with the surface decommissioning cost proportion of surface capital cost for the geologic repository. These costs have been distributed by year in proportion to the demolition contractor costs shown in reference III-4. The resulting decommissioning costs are shown in Table 4-6.

These costs have been discounted at 6.5 percent to the last year of operations (year 0 in Table 5-6) and the resulting value (\$19.94M) shown in the cost data in that year for each closed encapsulation plant. The previously defined partially used facility methodology has been applied to this value for encapsulation facilities which remain open after the horizon year of the continuous methodology scenarios.

Complete annual encapsulation O\&M and decommissioning costs for each case can be seen in Appendix A. 


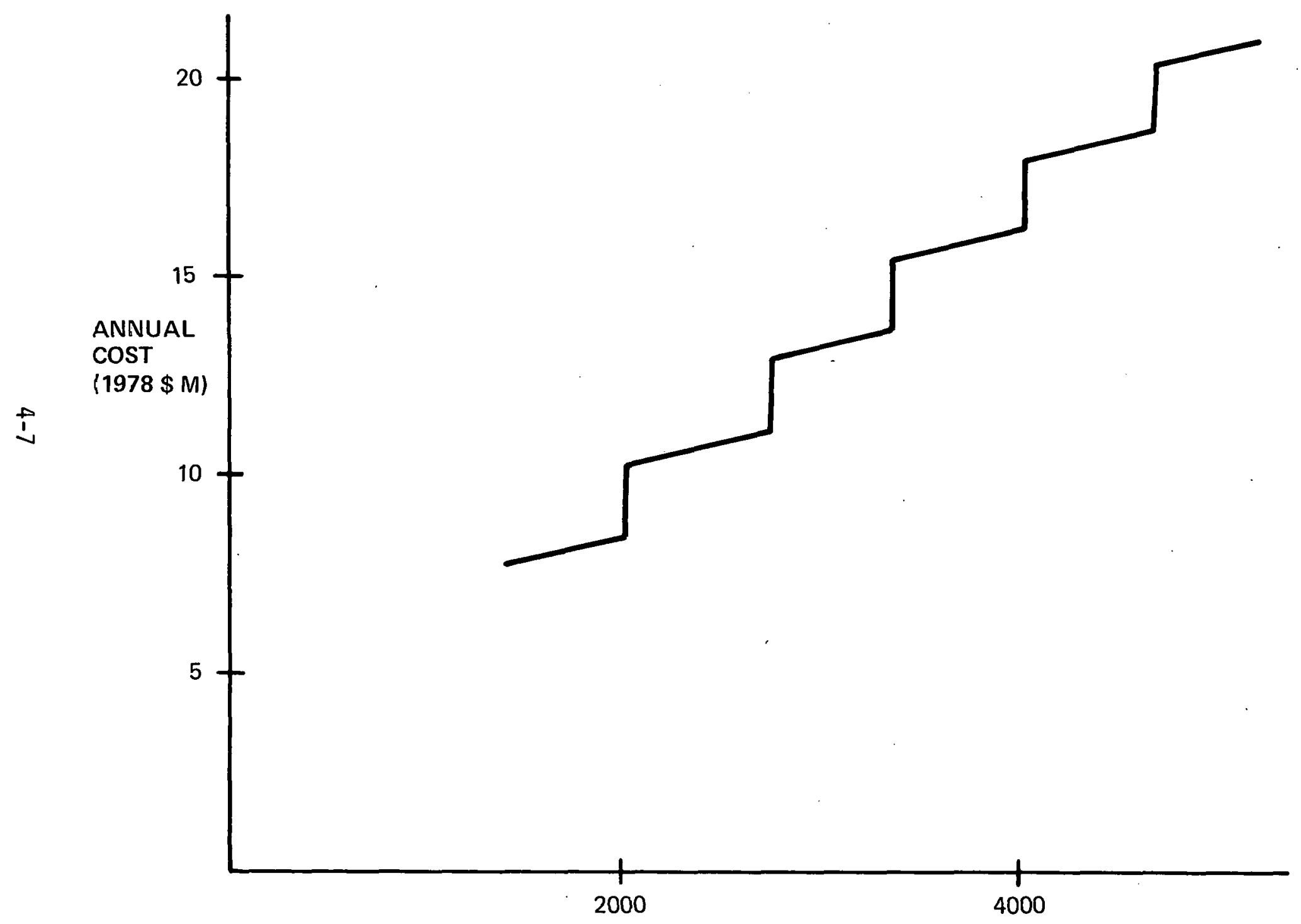

ANNUAL ENCAPSULATION RATE (MTU)

Figure 4-1. Encapsulation 0\&M Costs vs. Fuel Encapsulated 
Table 4-6. Encapsulation Decommissioning Costs

\begin{tabular}{|c|c|}
\hline YEAR & $\operatorname{COST}(1978 \$ M)$ \\
\hline 1 & 3.03 \\
\hline 2 & 3.44 \\
\hline 3 & 3.4 \\
\hline 4 & 3.39 \\
\hline 5 & 4.52 \\
\hline 6 & 4.4 \\
\hline 7 & 3.57 \\
\hline TOTAL & 25.75 \\
\hline
\end{tabular}




\subsection{AWAY FROM REACTOR STORAGE}

This chapter presents the assumptions and data sources used to estimate the Capital, 0\&M, and Decommissioning costs for the Away From Reactor (AFR) storage cost center. In this study, this cost center is required only in the cases of high receipts. It should be noted, however, that AFR storage capacity presents a reasonable contingency capability and must be considered on the basis of this criteria as well. Furthermore, since AFRs are assumed to be privately owned, the estimated costs in this chapter must not be confused with the charges to the government generated from these AFR costs using the Pricing Methodology described in Chapter 11. Appendix A displays the annual costs discussed only in this chapter. Charges to the government also include operator's return, taxes, and insurance, which are not addressed in this chapter.

\subsection{ASSUMPTIONS}

AFR storage is required if a scenario calls for fuel to be delivered to the government prior to the availability of geologic repository storage or in excess of repository receiving capability. If required, AFRs are assumed privately owned with after tax discounted return to the operator of 12 percent ${ }^{1}$. Dispersal of AFRs throughout the country was desirable to minimize transportation costs and to provide more easily available and backup emergency storage. In addition, building smaller facilities delays some expense to later years. However, economy of scale is gained by building facilities that are as large as possible.

Based on the capacity required by the flow scenarios discussed in Chapter 10, this study chose a middle range as the expected outcome of more detailed analyses of the above factors, specifically two 7000 MTU capacity AFRs.

AFR receiving rate was assumed to be 2000 MTU/yr. However, the study did not wish to restrict the mix of truck and rail receipts. Therefore, provision was made to build greater than 2000 MTU/yr. capacity but not use it, solely to provide both sufficient truck and rail receiving capacity.

\footnotetext{
$\overline{1}_{\text {Note that all other costs (including AFR charges to the government) were }}$ discounted at 6.5 percent.
} 
Finally, small capacities have been retained unused in each AFR so that surge storage will be available if necessary. The actual utilization of each AFR in this study is 91.4 percent. The first AFR is filled to this level before the second AFR is required, to defer capital expense as long as possible. Both AFRs are emptied simultaneously to uniformly distribute transportation and available capacity throughout the country.

\subsection{DATA SOURCES}

Figure 5-1 summarizes AFR capital cost from references $V-1,2$ and 3 on a consistent basis. This figure illustrates a scaling effect with slope generally decreasing slightly with increasing capacity and good correlation among the absolute levels of cost. Therefore, the DuPont values (reference $V-1$ ) were selected for use in this study. Two adjustments were made to the data as presented by DuPont. First, owner's cost of 10.2 percent, which excludes 1 and and interest during construction, was added for completeness and consistency with other cost centers. Second, storage baskets capitalized after start of operations by DuPont were included before the start of operation for this study. The latter assumption was made only for conservatism and did not change the cost of the facility, only its distribution by year. The basic contingency allowance of 25 percent (reference V-1) was not increased due to these changes.

The pricing methodology developed in Chapter 11 required separate costs for 1 and and working capital. Land costs were already contained in the DuPont data. Working capital was estimated as one month's average expenses over the life of the facility and ranged from $\$ 6.19 \mathrm{M}$ to $\$ 6.58 \mathrm{M}$. A complete display of AFR capital costs to the owner (for pricing methodology to derive cost to the government) is shown in Table $5-1$.

AFR O\&M costs were also taken from reference $V-1$ although they are supported in absolute level by reference $V-2$. Since AFR operations are almost entirely personnel oriented, no variation was considered due to changes in fuel received, so sufficient personnel were provided to handle maximum loads in all years. Therefore, in all years or partial years of AFR operations, \$6 M (1978) per AFR was charged for operations. During years of surveillance only, this value was reduced to $\$ 4 M$ (1978) per reference $V-1$. Both of these values used the average 1978 Savannah 
- IAEA-INFLATED TWO yeARS

- BECHTEL-O'NNER'S COST REMOVED, INFLATED TWO YEARS

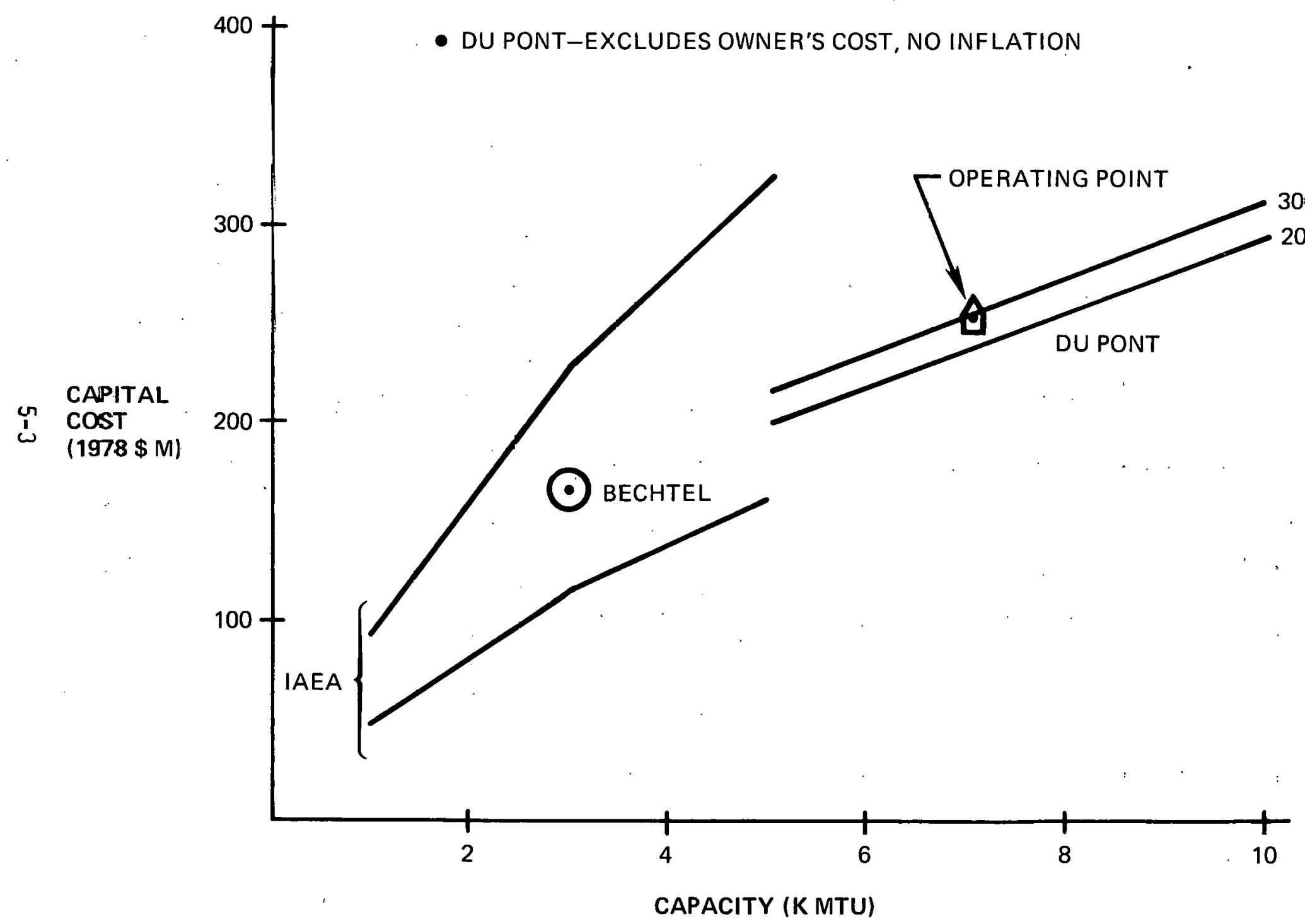

Figure 5-1. AFR Capital Costs 
Table 5-1. AFR Capital Costs

7000 MTU Capacity, 3000 MTU/yr Receiving Rate

Basic Source - Reference V-1

Owner's Cost - Bechtel Methodology

1978 \$M

\begin{tabular}{|c|c|c|c|c|c|}
\hline CATEGORY & TOTAL & YEAR 1 & YEAR 2 & YEAR 3 & YEAR 4 \\
\hline $\begin{array}{l}\text { CAPITAL1 } \\
\text { PLANT } \\
\text { STORAGE } \\
\text { OWASKETS } \\
\text { OWNER'S COST } \\
\text { LAND? }\end{array}$ & $\begin{array}{rr}273 & \\
& 204 \\
& 44 \\
& 25 \\
5 & \end{array}$ & $\begin{array}{l}15 \\
3\end{array}$ & $\begin{array}{rrr}34 & \dot{r} & y \\
& & j 7 \\
& & 14 \\
& & 3\end{array}$ & $\begin{array}{l}87 \\
14 \\
10\end{array}$ & $\begin{array}{l}87 \\
16 \\
10\end{array}$ \\
\hline TOTAL & 2.78 & 18 & 36 & 111 & 113 \\
\hline
\end{tabular}

I Inputs to Chapter 11 Price Methodology for computation of return, taxes, and insurance

River burdened cost per person of $\$ 40,000$. The total undiscounted 1978 costs of AFR operation in the two cases where AFRs were required were $\$ 160 \mathrm{M}$ and $\$ 136 \mathrm{M}$. Display of these costs by year will be found in Appendix $A$.

AFR decommissioning costs were estimated to be 10 percent of capital cost excluding owner's cost in constant dollars. This factor is commensurate with the surface facility decommissioning cost percentage of the geologic repository (reference III-4). These costs were distributed by year by TRW according to Table 5-2.

Table 5-2. AFR Decommissioning Costs 7000 MTU Capacity

3000 MTU/yr Receiving Rate

\begin{tabular}{|c|c|}
\hline YEAR & $1978 \$ \mathrm{M}$ \\
\hline 1 & 0 \\
2 & 9 \\
3 & 8 \\
\hline TOTAL & 25 \\
\hline
\end{tabular}

These costs were discounted at 6.5 percent into the last year of AFR operation (year 0 above, result $\$ 22.07 \mathrm{M}$ ) and charged in that year in the price calculation. Scenario ground rules required all AFRs to close within the years considered, so no partial trust fund methodology was applied to this cost center. 


\subsection{TRANSPORTATION}

This chapter presents the assumptions and data sources used to estimate the transportation cost of spent fuel between the AFR and the repository. Spent fuel is received $F O B$ at the designated first facility of the system. Therefore, total cost to a utility exceeds the costs shown in this document by the cost to transport its spent fuel over the first transportation link.

\subsection{ASSUMPTIONS}

AFR to repository transportation is assumed to be entirely by dedicated trains using IF-300 casks. Freight cost, dedicated train cost and cask leasing cost are addressed in this cost center. Costs for train service and cask lease, incurred in transporting spent fuel between the AFR and the repository, are affected by:

- Freight Rates

- Dedicated Train Rates

- Daily Cask Lease Rate

- Train Speed

- Facility Location.

Freight cost was calculated by summing loaded and empty costs for the full train. A 10 percent discount was included based on provisions of the ICC Act, Part I Section 22 which permits negotiated rates with government agencies. Dedicated train costs are assumed to be the product of cost per mile times distance for all segments (rail lines) of both loaded and empty trips.

Daily cask lease cost depends on the availability and replacement cost of IF-300 casks. A11 IF-300 casks and rail cars required are assumed to be prefinanced and available from the private sector with owner's profit included in the cask lease daily rate. Cask lease costs for a full train are assumed to be the product of cask lease daily rate times the length of the cask lease period. Facility locations assumed in this study 
for distance determinations were:

- AFR \#1 - Savannah River, S.C.

- AFR \#2 - Richland, Washington

- Repository - Southwestern U.S.

Division of distance by average speed of the dedicated train plus loading and unloading time yields the length of the cask leasing period. Finally, average cost of transporting a metric ton of uranium between the AFR and the repository is the total of the above rail service charges and the cask lease charge divided by total uranium moved in metric tons. The AFRs are assumed to be emptied uniformly in each year. Therefore, the average cost per MTU of the two facilities was multiplied by the uranium shipped to obtain the annual cost.

\subsection{DATA SOURCES}

The principal source of data for transportation custs is reference VI-1 which details research by OWI personnel into current nuclear transportation costs. This reference gives freight and dedicated train rates, IF-300 cask weights, cask capacities, train size and a range of daily cask lease rates. Both freight and dedicated train rates were discounted to account for any cost negotiations with the railroads. Additional research by OWI resulted in the following assumptions :

- Train speed will be 160 miles per day.

- Five day loading/unloading time.

This gives a greater train speed than is normally experienced on regular trains, but is somewhat less than the train speed that could be expected if all queueing were eliminated from regular train service. Total weights were used for calculating shipping costs; however, only the weight of uranium initially charged to the reactur was divided into metric tons of uranium shipped to calculate cost per ton. Fuel element breakdowns for PWR and BWR were calculated separately and combined using 40.2 percent PWR and 59.8 percent BWR derived from reference III-3. Table $6-1$ is a summary of both the inputs and the results of the calculations. It should be noted that cask lease cost constitutes more than 70 percent of al1 transportation costs. The yearly cost of transportation was calculated by multiplying the average total cost per MTU of $\$ 32,529$ by the yearly shipments. These costs will be seen in Appendix A. The total cost of transporting the 12,860 MTU AFR contents is \$417M (1978). 
TABLE 6-1. TRANSPORTATION SUMMARY

\begin{tabular}{|c|c|c|}
\hline & AFR \#1 & AFR \#2 \\
\hline \multicolumn{3}{|l|}{ Inputs } \\
\hline \multicolumn{3}{|l|}{ Freight Rate $(\$ / c w t)$} \\
\hline Loaded & 5.68 & 7.62 \\
\hline Empty & 5.31 & 7.15 \\
\hline \multicolumn{3}{|l|}{ Dedicated Train } \\
\hline \multicolumn{3}{|l|}{ First Segment } \\
\hline Rate $(\$ /$ mi le $)$ & 19.69 & 17.93 \\
\hline Distance (one way miles) & 640 & 1675 \\
\hline \multicolumn{3}{|l|}{ Second Segment } \\
\hline Rate $(\$ /$ mile $)$ & 19.72 & - \\
\hline Distance (one way miles) & 967 & - \\
\hline Cask Lease Rate ( $\$ /$ day) & 3000 & 3000. \\
\hline \multicolumn{3}{|l|}{ Cost $(\$ / M T U)$} \\
\hline Freight & 4,094 & 5,502 \\
\hline Dedicated Train & 4,371 & 4,145 \\
\hline Cask Lease & 23,082 & 23,864 \\
\hline TOTAL & 31,547 & 33,511 \\
\hline
\end{tabular}




\subsection{RESEARCH AND DEVELOPMENT}

This chapter discusses the research and development (R\&D) costs which are included in this study for complete recovery of all government costs. Assumptions made, coverage of the costs, and source of the data are enumerated to assure an understanding of the resulting impact on price. Identical R\&D costs are included in all four cases.

Since government R\&D funds have been and will be expended in support of commercial spent fuel management, their recovery through these management charges is reasonable and logical by evenly distributing the expense of nuclear electricity generation. R\&D costs have been included for various geologic media in which spent fuel placement has been considered and for all interim management methods and processes under study or reasonably predictable. Certainly other reasonable estimates of commercial spent fuel R\&D costs could be constructed. However, the coverage and representative values used here represent the best values available to date for pricing of commercial spent fuel management.

The costs include expenditures of the DOE's Office of Waste Isolation, Nevada Operations, and Richland Operations' terminal storage projects. Major programs contained in these costs include the Lyons, Kansas project, the Encapsulation Program, and the. Spent Unreprocessed Fuel Facility Program. Both expended and predicted expenses are included. Expended $R \& D$ funds are not negatively discounted (inflated); however, future R\&D is discounted for pricing purposes.

The sourre of the R\&D cost values is reference VII-1. Figure 7-1 illustrates these values. The numerical values will be found in the detailed cost data of all four cases in Appendix A. Because of the sensitive nature of future budget projections, the detailed breakdown of these values was not available to TRW since they were not required for the calculation of a spent fuel management price. 


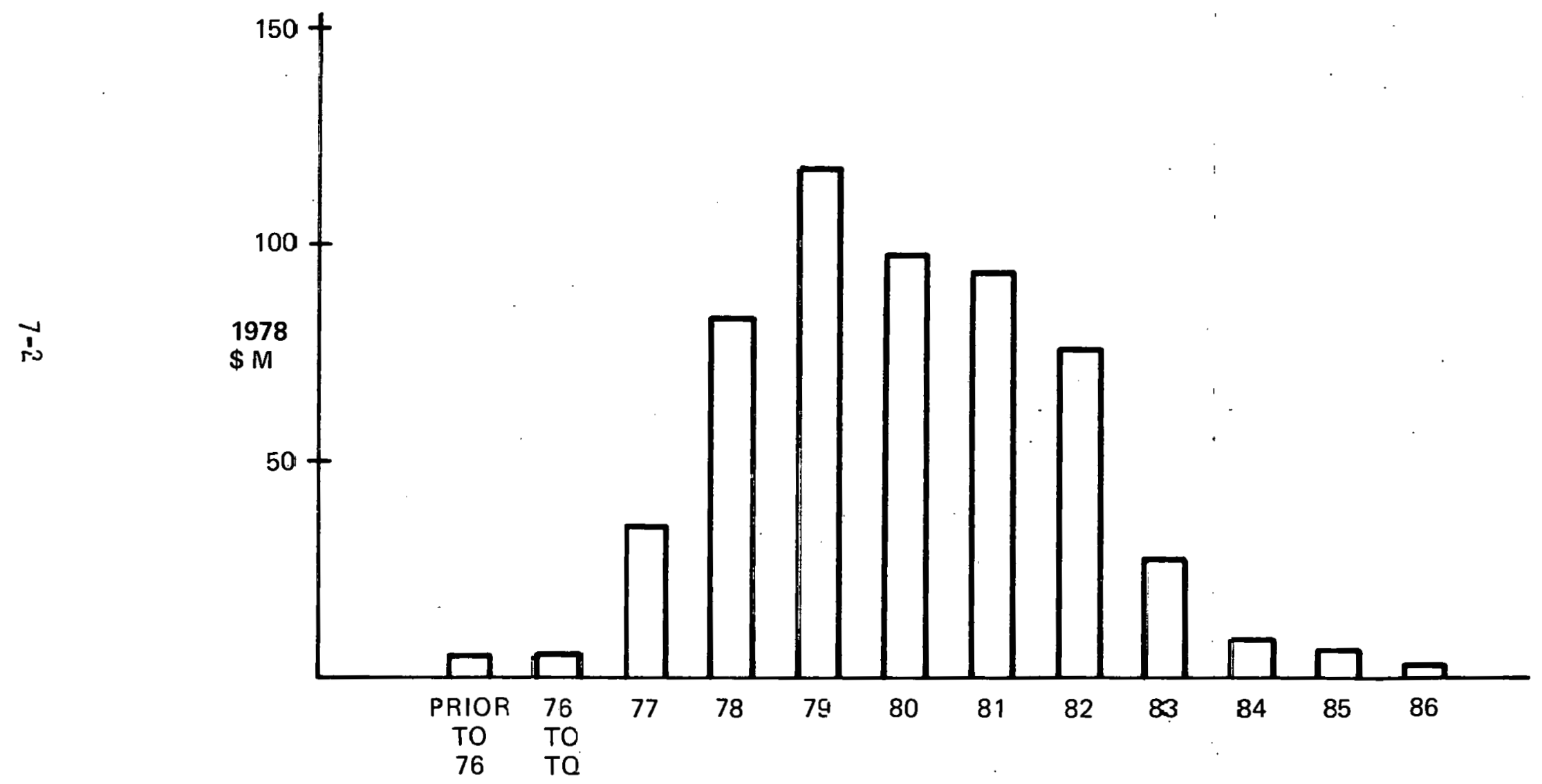

Figure 7-1. Research and Development Cost 


\subsection{GOVERNMENT OVERHEAD}

This chapter discusses the assumptions and data sources supporting the costs included in the government overhead cost center. These costs were included to assure recovery of all costs associated with the commercial spent fuel management program. They are intended to represent al1 non-R\&D expenses to the government not directly associated with the operation of the other cost centers and, therefore, excluded from all other costs.

In estimating these costs, consideration was given to the overhead costs included in the price of uranium enrichment services provided by the government. This program is larger in cost than the spent fuel management program, but includes large amounts of purchased electricity. The number of facility cost centers is approximately the same. Therefore, it is assumed that annual government overhead costs will be identical to those of the enrichment program in the years in which spent fuel is received.

In years of capital construction, these or similar costs have already been accounted for as owner's cost in each facility cost center and in the R\&D costs.

The enrichment program costs used were obtained from reference VIII-7. Table 8- 1 enumerates the value of these costs.

Table 8-1. Government Overhead Annual Custs

\begin{tabular}{|c|c|}
\hline CATEGORY & $1978 \$ M$ \\
\hline Community Support & 1 \\
Security & 3 \\
Government Support & 9 \\
\hline TOTAL & 13 \\
\hline
\end{tabular}

The resulting cost data are shown for all four cases in Appendix A. Total undiscounted 1978 costs for the four cases range from $\$ 195$ to $\$ 234 \mathrm{M}$. 


\subsection{SPENT FUEL QUANTITY}

This chapter presents the assumptions and data sources of this study relating to spent fuel discharged by reactors and constraints imposed on spent fuel handling by system components. These data will be combined with scenario assumptions in chapter 10 to yield complete spent fuel flows for four cases.

\subsection{REACTOR DISCHARGES}

This study assumes that U.S. reactor discharges will be those of reference $I X-1$. These discharges increase continuously as nuclear generating capacity increases to 380 GWe installed by the year 2000 . This reference assumes conservative reactor characteristics. ${ }^{1}$ Reference IX-1 further shows an existing backlog of spent fuel in 1976 of 2270 MTU.

Foreign fuel discharges were estimated in reference IX-2. Ten percent of candidate foreign fuel was assumed delivered to the spent fuel management system. A foreign backlog of 600 MTU in 1976, as shown in this reference, was also accepted. Table 9-1 summarizes the GWe installed and discharges assumed in this study.

\subsection{STORAGE CAPACITY AND HANDLING CONSTRAINTS}

The facilities costed in this study were set up to balance the capital building costs with the maximum system lifetime requirements. This section describes these constraints for each cost center involved which are:

- Afr

- Encapsulation

- Geologic repository.

The AFR storage capacity selected was near the midrange of the total capital cost relationship used. A limit of 2000 MTU per year was placed on the AFR spent fuel receiving capacity; sufficient capacity was costed to provide 3000 MTU per year receiving capacity. Both truck and rail

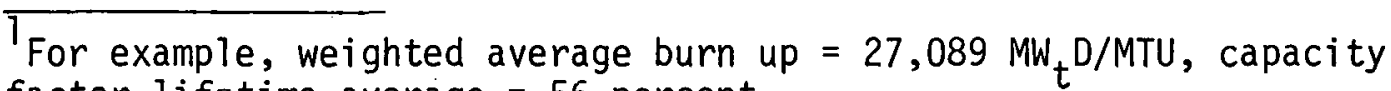
factor lifetime average $=56$ percent . 
Table 9-1 Nuclear Generating Capacity and Discharges

\begin{tabular}{|c|c|c|c|}
\hline Year & U.S. GWe Installed & U.S.Discharge (MTU) & Foreign Discharge (MTU) \\
\hline Prior & 42.7 & 2270 & 600 \\
1977 & 51.2 & 1050 & 300 \\
1978 & 55.1 & 1230 & 200 \\
1979 & 60.6 & 1380 & 400 \\
1980 & 65.8 & 1510 & 300 \\
1981 & 70.5 & 1660 & 400 \\
1982 & 82.3 & 1790 & 400 \\
1983 & 93.5 & 1990 & 400 \\
1984 & 109.2 & 2280 & 500 \\
1985 & 126.5 & 2620 & 500 \\
1986 & 140.6 & 3040 & 600 \\
1987 & 153.2 & 3450 & 700 \\
1988 & 165.8 & 3790 & 700 \\
1989 & 179.3 & 4120 & 800 \\
1990 & 194.4 & 4440 & 1000 \\
1991 & 210.2 & 4800 & 900 \\
1992 & 227.0 & 5170 & 1100 \\
1993 & 243.8 & 5560 & 1200 \\
1994 & 262.7 & 5970 & 1200 \\
1995 & 282.5 & 6390 & 1400 \\
1996 & 302.3 & 6850 & 1400 \\
1997 & 322.1 & 7320 & 1600 \\
1998 & 341.9 & 7790 & 1600 \\
1999 & 361.7 & 8250 & 1700 \\
2000 & 379.7 & 8700 & 1800 \\
& & & $\cdots$ \\
\hline
\end{tabular}


receiving facilities are arranged to handle either mode of transportation selected by the utilities. This excess capacity also provides reasonable expectation of achieving the maximum receiving capacities as required in the early years.

In costing the encapsulation facility, scaling techniques were used which tripled the processing capacity of the base estimate. Chapter 4 gives a detailed description of this calculation.

The geologic repository costs were based on the following assumptions.

- Storage capacity meets original design specifications.

- Receiving constraints are not exceeded.

The constraints used to cost each facility are detailed in Table 9-2. Each facilities flow was examined; if constraints were violated, receipts were deferred by taking less backlog or by rearranging the facility schedule to provide additional capacity. 
Table 9-2 Spent Fuel Handling Constraints

\begin{tabular}{|l|c|c|}
\hline Facility & Receiving Rate (MTU/YR) & Capacity (MTU) \\
\hline AFR & 2000 & $7000^{7}$ \\
\hline Encapsulation & & \\
First & 6000 & N/A \\
Second & 9000 & N/A \\
\hline Geologic Repository & & $52,500^{2}$ \\
First & & \\
Initial 5 years & 1780 & $104,700^{3}$ \\
Final & 5320 & \\
Second & & \\
Initial 5 years & 3000 & \\
Final & 9000 & \\
\hline
\end{tabular}

Tonly 91.4 percent utilized

${ }^{2}$ For all 10-year-old retrievable fuel at emplacement, 44,200 for 5-year-old fuel ${ }^{3}$ Five-year retrievability 


\subsection{SCENARIOS}

This chapter presents the detailed scenarios used to price four spent fuel management cases. Two scenario variables were combined for two values each. Assumptions regarding these variables are presented in the first two sections. The detailled spent fuel flows by year and by facility resulting from these combinations are presented and discussed in the final section. Detailed costs for each scenario will be found in Appendix A.

\subsection{SPENT FUEL INPUT RATE}

If most utilities choose to deliver as much spent fuel as permissible under government policy, the government spent fuel management system must be prepared for high early values, after a 5-year notification lag. This decision can be expected if utilities have confidence in the system and they find at-reactor storage impractical, too great a regulatory problem or too expensive. On the other hand, if utilities elect to retain their spent fuel for expected residual value and have or build sufficient storage at reactors, then the government spent fuel management system must be prepared for low delivery rates.

In order to create a high and a low delivery example, this study elected to examine cooling delays of five and ten years from the discharges defined in Chapter 9. Both foreign and U.S. fuel were delayed five and ten years; foreign fuel was accepted only through 1990. Thus the foreign receipts were also high and low, constituting 4000 and 1800 MTU, respectively. Both high and low flow cases accepted the identical pre 1978 U.S. and foreign backlogs of 4220 NTU (Reference IX -1 and IX-2). The earliest delivery occurred in the high flow cases only. Contracts were expected to be executed in 1978 for receipt of spent fuel in 1983.

Display and discussion of these complete flows is deferred to the end of this chapter because of their interrelationship with the second scenario variable. These flows must not be interpreted as forecasts of utility positions. No survey or analys is was conducted to estimate the best value. They are, however, illustrative of flows that the system might be required to process regardless of the source of the input and so they represent a reasonable baseline for analysis. 


\subsection{FINANCIAL STRUCTURE}

Two approaches to financial structure formed the second variable for scenario construction. In the first approach, only those costs necessary to build, fill, and prepare for decommissioning and post operations for a single geologic repository are considered. Naturally, only spent fuel receipts up to the capacity of a single geologic repository are charged these costs. This approach was called venture methodolgy because it approximates the treatment of a single project, the first repository, as an entity. In the five-year cooling delay, high fuel input case, this methodology (case 1) required that the repository remain open one year (1997) beyond the receipt by the system of its cumulative spent fuel capacity in order to emplace the final quantity of AFR stored spent fuel. In the ten-year,cooling delay, low fuel input case this methodology (case 3 ) results in costs through 2003 to reach capacity. Since all facilities are filled to capacity and completely utilized this methodology charged the full value of all trust funds and did not consider undepreciated value of facilities.

The second approach includes the cost of all system elements which would be required to manage all spent fuel expected to be received through an arbitrarily chosen horizon year and retain the ability for continuous operations. The costs through the horizon year are then combined with the receipts through the horizon year to determine the price of spent fuel management. Undepreciated value (negative cost) is taken in the final year for existing facilities (straight line over lo years.' depreciation was selected). Also, trust fund values are adjusted to recognize their inclusion before need. This approach was called the compaign methodology and the year 2000 wás selected as the horizon year. Second repository opening was carefully placed to delay construction expenses as long as possible. Spent fuel received by the second repository during the initial five-year low receiving rate period left room for later spent fuel receipt at the first repository, thus delaying closing. In the high flow rate case the delay was one year while in the low flow rate case it was two years. In the high flow rate case the extra receiving capacity of the second repository also allowed earlier closing of AFR storage, thus creating some cost saving. This delay in first repository closing postpones the need for the high receiving rate mature phase of the second repository. This allows the desired delay in the second repository construction schedule. 
This methodology does not consider whether a specific delivery of spent fuel does or does not use the second repository in deriving its price. This assumes that users of the second repository will be essentially the same as users of the first repository.

\subsection{SCENARIO SUMMARY}

Table 10-1 enumerates the case numbers assigned to scenario combinations and summarizes the principal inputs to the four cases of this study. Note that in the venture Cases 1 and 3, the receipts shown represent repository capacity, while the campaign Cases 2 and 4 both close in the year 2000 .

Table 10-1. Scenario Summary

\begin{tabular}{|l|l|l|l|l|}
\hline \multicolumn{1}{|c|}{ CASE NO. } & 1 & 2 & 3 & 4 \\
\hline Spent Fuel Delivery Rate & High & High & Low & Low \\
Closure Methodology & Venture & Campaign & Venture & Campaign \\
Receipts (MTU) & 44,200 & 68,510 & 52,500 & 38,420 \\
Closing Year & 1997 & 2000 & 2003 & 2000 \\
\hline
\end{tabular}

The detailed spent fuel flow for each case is seen in Tables 10-2 through 10-5, respectively. These flows show the result of combining the discharge data of Chapter 9 with the scenario assumptions above. Tables 10-2 and 10-3 show the five-year cooling delay high flow cases. These are identical through 1993. Note that the U.S. and foreign backlog was accepted from 1983 through 1987. In Case 2, the second repository opens in 1994., providing sufficient capacity to empty the AFRs over the next two years. The receiving rate of the first repository is then reduced to defer closing. This defers the need for the high receiving rate mature phase of the second repository which provides the desired delay in the start of second repository construction.

Tables 10-4 and 10-5 show the ten-year cooling low flow cases. They are identical through 2000. The acceptance of U.S. and foreign backlog was completed in 1991. Note that in 1990 U.S. and foreign candidate receipts exceeded capacity by 30 MTU ( 1.7 percent) requiring this amount to be deferred one year with no backlog accepted. Only the flow through 2000 was used 
Table 10-2. Spent Fuel Flow - Case 1

Five-Year Delay, Venture Methodology

(Units: MTU)

\begin{tabular}{|c|c|c|c|c|c|c|c|c|c|}
\hline \multirow[b]{3}{*}{ YEAR } & \multirow{2}{*}{\multicolumn{3}{|c|}{ RECEIPTS }} & \multicolumn{6}{|c|}{ ALLOCATION } \\
\hline & & & & \multicolumn{2}{|c|}{ AT AFR } & \multicolumn{2}{|c|}{ AT REPOSIT I } & \multicolumn{2}{|c|}{ AT REPOSIT II } \\
\hline & U.S. & FORGN & ACCUM & ANINUAL & ACCUN. & ANNUAL & ACCUM & ANNUAL & ACCUM \\
\hline 1983 & 1230 & 770 & 2000 & 2000 & 2000 & 0 & 0 & 0 & 0 \\
\hline 1984 & 1380 & 620 & 4000 & 2000 & 4000 & 0 & 0 & 0 & 0 \\
\hline 1985 & 2610 & 410 & 7020 & 3000 & 7000 & 20 & 20 & 0 & 0 \\
\hline 1986 & 2810 & 400 & 10230 & 1430 & 8430 & 1780 & 1800 & 0 & 0 \\
\hline 1987 & 2860 & 400 & 13490 & 1480 & 9910 & 1780 & 3580 & 0 & 0 \\
\hline 1988 & 1990 & 400 & 15880 & 610 & 10520 & 1780 & 5360 & 0 & 0 \\
\hline 1989 & 2280 & 500 & 18660 & 1000 & 11520 & 1780 & 7140 & 0 & 0 \\
\hline 1990 & 2620 & 500 & 21730 & 1340 & 12860 & 1780 & 8920 & 0 & 0 \\
\hline 1991 & 3040 & 0 & 24320 & -2230 & 10580 & 5320 & 14240 & 0 & 0 \\
\hline 1992 & 3450 & 0 & 28270 & -1870 & 8710 & 5320 & 19560 & 0 & 0 \\
\hline 1993 & 379.0 & 0 & 32060 & -1530 & 7130 & 5320 & 24880 & 0 & 0 \\
\hline 1994 & 4120 & 0 & 36180 & -1200 & 5930 & 5320 & 30200 & 0 & 0 \\
\hline 1995 & 4440 & 0 & 40620 & -890 & 5100 & 5320 & 35520 & 0 & 0 \\
\hline 1996 & 3580 & 0 & 44200 & -1740 & 3360 & 5320 & 40840 & 0 & 0 \\
\hline 1997 & 0 & 0 & 44200 & -3360 & 0 & .3360 & 44200 & .0 & 0. \\
\hline
\end{tabular}

FORGiv: Foreign

Accur: Accumulated

REPOSIT: Repository 
Table 10-3. Spent Fuel Flow - Case 2

Five-Year Delay, Campaign Methodology

(Units: MTü)

\begin{tabular}{|c|c|c|c|c|c|c|c|c|c|}
\hline \multirow{3}{*}{ YEAR } & \multirow{2}{*}{\multicolumn{3}{|c|}{ RECEIPTS }} & \multicolumn{6}{|c|}{ ALLOCATION } \\
\hline & & & & \multicolumn{2}{|c|}{ AT AFR } & \multicolumn{2}{|c|}{ AT REPOSIT I } & \multicolumn{2}{|c|}{ AT REPOSIT II } \\
\hline & U.S. & FORGM & ACCUM & AilNUAL & ACCUM & AiiliUUAL & ACCUM & ANNUAL & ACCUH \\
\hline 1983 & 1230 & 770 & 2000 & 2000 & 2000 & 0 & 0 & 0 & 0 \\
\hline 1984 & 1380 & 620 & 4000 . & 2000 & 4000 & 0 & 0 & 0 & 0 \\
\hline 1985 & 2610 & 410 & 7020 & 3000 & 7000 & 20 & 20 & 0 & 0 \\
\hline 1986 & 2810 & 400 & 10230 & 1430 & 8430 & 1780 & 1800 & 0 & 0 \\
\hline 1987 & 2860 & 400 & 13490 & 1480 & 9910 & 1780 & 3580 & 0 & 0 \\
\hline 1988 & 1990 & 400 & 15880 & 610 & 10520 & 1730 & 5360 & 0 & 0 \\
\hline 1989 & 2280 & 500 & 18660 & 1000 & 11520 & 1780 & 714.0 & 0 & 0 \\
\hline 1990 & 2620 & 500 & 21780 & 1340 & 12860 & 1780 & 8920 & 0 & 0 \\
\hline 1991 & 3040 & 0 & 24820 & -2230 & 10530 & 5320 & 14240 & 0 & 0 \\
\hline 1992 & 3450 & 0 & 28270 & -1870 & 8710 & 5320 & 19560 & 0 & 0 \\
\hline 1993 & 3790 & 0 & 32060 & -1530 & 7180 & 5320 & 24880 & . 0 & 0 \\
\hline 1994 & 4120 & 0 & 36180 & -4000 & 3130 & 5320 & 30200 & 2800 & 2800 \\
\hline 1995 & 4440 & 0 & 40620 & -3180 & 0 & 5320 & 35520 & 2300 & 5100 \\
\hline 1996 & 4800 & 0 & 45420 & 0 & 0 & 3060 & 38580 & 1740. & 6840 \\
\hline 1997 & 5170 & 0 & 50590 & 0 & 0 & 3060 & 41640 & 2110 & 8950 \\
\hline 1998 & 5560 & 0 & 56150 & 0 & 0 & 2560 & 44200 & 3000 & 11350 \\
\hline 1999 & 5970 & 0 & 62120 & 0 & 0 & 0 & 44200 & 5970 & 17920 \\
\hline 2000 & 6390 & 0 & 68510 & 0 & 0 & 0 & 44200 & 6390 & 24310 \\
\hline
\end{tabular}

FORGIV: Foreign

ACCUM: Accumulated

REPOSIT: Repository 
Table 10-4. Spent Fuel Flow - Case 3

Ten-Year Delay, Venture Methodology

(Units: MTU)

\begin{tabular}{|c|c|c|c|c|c|c|c|c|c|}
\hline \multirow[b]{3}{*}{ YEAR } & \multirow{2}{*}{\multicolumn{3}{|c|}{ RECEIPTS }} & \multicolumn{6}{|c|}{ ALLOCATION } \\
\hline & & & & \multicolumn{2}{|c|}{ AT AFR. } & \multicolumn{2}{|c|}{ AT REPOSIT I } & \multicolumn{2}{|c|}{ AT REPOSIT II } \\
\hline & U.S. & FORGN & ACCUM & ANNUAL & ACCUM & AivivUAL & ACCUM & AIJNUAL & ACCUM \\
\hline 1932 & 0 & 0 & 0 & 0 & 0 & 0 & 0 & 0 & 0 \\
\hline 1983 & 0 & 0 & 0 & 0 & 0 & 0 & 0 & 0 & 0 \\
\hline 1984 & 0 & 0 & 0 & 0 & 0 & 0 & 0 & 0 & 0 \\
\hline 1985 & 20 & 0 & 20 & 0 & 0 & 20 & 20 & 0 & 0 \\
\hline 1986 & 1180 & 600 & 1800 & 0 & 0 & 1780 & 1800 & 0 & 0 \\
\hline 1987 & 1480 & 300 & 3580 & 0 & 0 & 1780 & 3580 & 0 & 0 \\
\hline 1988 & 1580 & 200 & 5360 & 0 & 0 & 1780 & 5360 & 0 & 0 \\
\hline 1989 & 1380 & 400 & 7140 & 0 & 0 & 1780 & 7140 & 0 & 0 \\
\hline 1990 & 1480 & 300 & 8920 & 0 & 0 & 1780 & 8920 & 0 & 0 \\
\hline 1991 & 1980 & 0 & 10900 & 0 & 0 & 1980 & 10900 & 0 & 0 \\
\hline 1992 & 1790 & 0 & 12690 & 0 & 0 . & 1790 & 12690 & 0 & 0 \\
\hline 1993 & 1990 & 0 & 14680 & 0 & U & 1990 & 14680 & 0 & 0 \\
\hline 1994 & 2280 & 0 & 16960 & 0 & 0 & 2280 & 16960 & 0 & 0 \\
\hline 1995 & 2820 & 0 & 19500 & 0 & 0 & 2620 & 19580 & $n$ & $n$ \\
\hline 1996 & 3040 & 0 & 22620 & 0 & 0 & 3040 & 22620 & 0 & 0 \\
\hline 1997 & 3450 & 0 & 26070 & 0 & 0 & 3450 & 26070 & 0 & 0 \\
\hline 1998 & 3790 & 0 & 29860 & 0 & 0 & 3790 & 29860 & 0 & 0 \\
\hline 1999 & 4120 & 0 & 33980 & 0 & 0 & 4120 & 33980 & 0 & 0 \\
\hline 2000 & 4440 & 0 & 38420 & 0 & 0 & 4440 & 33420 & 0 & 0 \\
\hline 2001 & 4800 & 0 & 43220 & 0 & 0 & 4800 & 43220 & 0 & 0 \\
\hline 2002 & 5170 & 0 & 48390 & 0 & 0 & 5170 & 48390 & 0 & 0 \\
\hline 2003 & 4110 & 0 & 52500 & 0 & 0 & 4110 & 52500 & 0 & 0 \\
\hline
\end{tabular}

FORGiv: Foreign

ACCUM: Accumulated

REPOSIT: Repository 
Table 10-5. Spent Fuel Flow - Case 4

Ten-Year Delay, Campaign Methodology

(Units: MTU)

\begin{tabular}{|c|c|c|c|c|c|c|c|c|c|}
\hline \multirow[b]{3}{*}{ YEAR } & \multicolumn{3}{|c|}{ RECEIPTS } & \multicolumn{6}{|c|}{ ALLOCATION } \\
\hline & & & & \multicolumn{2}{|c|}{ AT AFR } & \multicolumn{2}{|c|}{ AT REPOSIT I } & \multicolumn{2}{|c|}{ AT REPOSIT - II } \\
\hline & U.S. & FORGN & ACCUM & ANINUAL & ACCUM & ANNUAL & ACCUM & AINNUAL & ACCUM \\
\hline 1982 & 0 & 0 & 0 & 0 & 0 & 0 & 0 & 0 & 0 \\
\hline 1983 & 0 & 0 & 0 & 0 & 0 & 0 & 0 & 0 & 0 \\
\hline 1984 & 0 & 0 & 0 & 0 & 0 & 0 & 0 & 0 & 0 \\
\hline 1985 & 20 & 0. & 20 & 0 & 0 & 20 & 20 & 0 & 0 \\
\hline 1986 & 1180 & 600 & 1800 & 0 & 0 & 1780 & 1800 & 0 & 0 \\
\hline 1987 & 1480 & 300 & 3580 & 0 & 0 & 1780 & 3580 & 0 & 0 \\
\hline 1938 & 1580 & 200 & 5360 & 0 & 0 & 1780 & 5360 & 0 & 0 \\
\hline 1989 & 1380 & 400 & 7140 & 0 & 0 & 1780 & 7140 & 0 & 0 \\
\hline 1990 & 1480 & 300 & 8920 & 0 & 0 & 1780 & 8920 & 0 & 0 \\
\hline 1991 & 1980 & 0 & 10900 & 0 & 0 & 1980 & 10900 & 0 & 0 \\
\hline 1992 & 1790 & 0 & 12690 & 0 & 0 & 1790 & 12690 & 0 & 0 \\
\hline 1993 & 1990 & 0 & 14680 & 0 & 0 & 1990 & 14680 & 0 & 0 \\
\hline 1994 & 2280 & 0 & 16960 & 0 & 0 & 2280 & 16960 & 0 & 0 \\
\hline 1995 & 2620 & 0 & 19580 & 0 & 0 & 2620 & 19580 & 0 & 0 \\
\hline 1996 & 3040 & 0 & 22620 & 0 & 0 & 3040 & 22620 & 0 & 0 \\
\hline 1997 & 3450 & 0 & 26070 & 0 & 0 & 3450 & 26070 & 0 & 0 \\
\hline 1998 & 3790 & 0 & 29860 & 0 & 0 & 3790 & 29860 & 0 & 0 \\
\hline 1999 & 4120 & 0 & 33980 & 0 & 0 & 4120 & 33980 & 0 & 0 \\
\hline 2000 & 4440 & 0. & 38420 & 0 & 0 & 4440 & 38420 & 0 & 0 \\
\hline 2001 & 4300 & 0 & 43220 & 0 & 0 & 1800 & 40220 & 3000 & 3000 \\
\hline 2002 & 5170 & 0 & 48390 & 0 & 0 & 2170 & 42390 & 3000 & 6000 \\
\hline 2003 & 5560 & 0 & 53950 & 0 & 0 & 2560 & 44950 & 3000 & 9000 \\
\hline 2004 & 5970 & 0 & 59920 & 0 & 0 & 2970 & 47920 & 3000 & 12000 \\
\hline 2005 & 6390 & 0 & 66310 & 0 & 0 & 4580 & 52500 & 1810 & 13810 \\
\hline
\end{tabular}

FORGN: Foreign

ACCUM: Accumulated

REPOSIT: Repository 
in Case 4. The entire flow through first repository closing in 2005 is shown in Table 10-5 to illustrate the required process of establishing the impact of the initial phase in order to place the start of capital construction.

Each case priced in this study has unique strengths supporting its reasonable use as a baseline. High flow cases (1 \& 2) illustrate inclusion of AFR and transportation cost centers. Low flow cases ( 3 \& 4 ) show the impact of lower deferred revenues. The venture methodology, as applied in Cases 1 and 3, minimizes assumptions and therefore is based on the most supportable data. The campaign methodology, as applied in Cases 2 and 4 , presents a formulation which can be used continuously through any eventuality. Therefore, the results will represent broadly based variations carefully constructed to present prices representing a range of views of the spent fuel management program. 


\subsection{PRICING METHODOLOGY}

This chapter discusses the methodology used by this study to derive the price of spent fuel management from the costs and spent fuel flows described in earlier chapters. Complete lists of equations used, variable meanings, and parameter values will be found in Appendix C.

\subsection{PRICING CONSTRAINTS}

The basic spent fuel pricing constraint of the entire analysis is:

- The discounted value of all relevant government costs must be exactly recovered by the discounted value of all applicable revenues received over the life of the program. An equivalent statement would be that the present value (PV) of all costs must equal the PV of all revenues.

Another important constraint is that:

- Price is imposed on a one-time basis only. That is, once a fee has been established for a particular shipment, there will be no retroactive adjustments.

But it should be noted that an adjustment of prices might occur if spent fuel were to be retrieved and reprocessed. However, in this analysis, such a possibility is not considered and no credits for the $\mathrm{Pu}$ and $\mathrm{U}^{235}$ values in the spent fuel are included.

Another constraint is that:

- The costs of post operational surveillance of the buried material, starting at the time that the final repository of the spent fuel is decommissioned, must be included in the price.

Finaliy, a requirement of the analysis was that:

- The components of price associated with the various cost centers have to be calculated and published along with the total price.

In connection with the above requirement, it must be emphasized that there is no necessary connection between the cost directly generated at a cost center by a particular shipment and the value of the price component allocated to that shipment. This point will be explained more fully in paragraph 11.3 .

\subsection{PRICING ASSUMPTIONS}

The following assumptions were used in deriving the price methodology. 
Where appropriate, rationale and/or comments on the assumptions are presented.

1. Price components correspond to the following cost centers which were identified in reference XI-1 and shown in Table 11-1.

Table 11-1. Spent Fuel Management Cost Centers

\begin{tabular}{|l|l|}
\hline \multicolumn{1}{|c|}{ Cost Center } & \multicolumn{1}{|c|}{ Comment } \\
\hline 1. Away From Reactor (AFR) storage & $\begin{array}{l}\text { In certain cases, an AFR will not } \\
\text { be needed. But complete formulas } \\
\text { for AFR pricing are given. }\end{array}$ \\
2. Encapsulation facility & $\begin{array}{l}\text { May be colocated with repositories. } \\
\text { This cost center includes perpetual } \\
\text { surveillance costs. }\end{array}$ \\
3. Geologic repository & $\begin{array}{l}\text { Only government costs inciuded. } \\
\text { Government funded R\&D only. } \\
\text { 5. Research \& Development (R\&D) } \\
\text { 6. Government overhead }\end{array}$ \\
\hline
\end{tabular}

2. The pricing algorithms, except as specifically noted, follow as closely as possible the methodology used by DOE to price uranium enrichment separative work units (SWU). This ground rule was established by OWI at a meeting at Germantown, Md. on December 13,1977 . The rationale is that use of the SWU procedures would he rompatibie with provisions of the Atomic [nergy Ail ur 1954, as amended in 1973, which requires recovery of government cost, including imputed interest and depreciation charges (reference $X I-2)$.

3. The time horizon for the pricing formulas extends from the base year, 1978, to the end year of the scenario. However, there are provisions for recovery of any undepreciated government capital still on the books at the end of the scenario. 
Undepreciated book value is determined as follows. All government capital is assumed to be completely depreciated after ten or more years of beneficial use. If capital is beneficially used for less than ten years, depreciation is calculated by the straight-line method assuming a ten-year depreciation life. There is no salvage value for either government or privately owned facilities. The above assumptions were established by DOE/OWI at a meeting held at Oak Ridge, Tennessee on December 2, 1977.

4. All calculations for establishment of the initial price are in terms of constant 1978 dollars. Such an assumption is compatible with an option to recompute prices.

5. All incremental government costs (capital as well as operating) are recognized for discounting purposes in the year incurred. The above procedure is equivalent to recapture of government inputed interest and depreciation charges as required by the Atomic Energy Act of 1954. A proof of the equivalence of the two methods is given in Appendix $D$ of this report.

6. A11 government revenues are recognized for discounting purposes in the year that spent fuel is first received at a designated site. Title to the spent fuel is assumed to be transferred to the government at the point of first receipt.

7. In addition to incremental costs, one category of sunk costs is recognized which pertains to spent fuel storage R\&D performed before 1978. These costs are all recognized in the base year of 1978. The rationale for inclusion of sunk costs is that such costs must be recovered to be consistent with the basic conslraint of the pricing analysis. However, if the algorithms developed are ever used for system evaluations, only marginal costs should be considered. 
8. For purposes of discounting, costs and revenues are assumed to be generated at the beginning of each time period while interest charges are assumed to be due and payable at the end of each period. Further, beneficial use of a facility is assumed to continue for one full period after the last charge (other than interest) for a facility is incurred.

9. Post operational activities at various facllities are handled by an annuity or trust fund as follows:

a. Post operational costs for repository sites are covered by an annuity which will provide required annual funding to keep the repositoiry in ull upcraling mode in prrpetality. The annuity is purchased efther In lhe last year of sitc operation or the last year of the time horizon (whichever comes first). The cost of the annuity is recognized in the year of purchase for purposes of discounting. Funds are made available by withdrawal of simple interest earned by the annuity at the same rate as that assumed for government interest.

b. Decommissioning costs are covered by recognizing the PV of these costs in the last operational year of a site. In the repositories, seven years of post operational decommissioning costs are present valued while three years of decommissioning custs are included in the coste of the last year of AFR operations. The values of these costs will be found in earlier chapters.

10. The discount rate for costs and revenues and the imputed government interest rate are assumed to be the same as they are in the SWU pricing formulas.

11. A11 AFR sites are assumed to be privately owned and operated by unregulated corporations. It is assumed that the private owner would bill the government for an amount which would cover operations costs and capital recovery charges. Payments to the AFR owners would be a government cost recogniced as incurred.

If the AFR were government owned, the procedures used to calculate the PV of encapsulation costs would be applicable to the AFR. If the AFR were utility owned, all AFR formulas developed would apply. Also, all parameter values, except for the return rate, would be the same. (The utilities cost of capital would be the return rate.) 


\subsection{PROCEDURES}

\section{II.3.I General Procedures}

The basic formula for calculation of the intial price is derived as follows.

From the basic constraint, the PV of government costs must equal the PV of government revenues. If $C_{t}$ is government costs incurred in the $t$-th year, $R_{t}$ is revenue received in the $t$-th year, $b$ is the base year (1978) and $S_{z}$ the last year of scenario " $z$ ", the constraint equation is:

$$
\sum_{t=y-b}^{S_{z}-b} \frac{c_{t}}{(k+d)^{t}}=\sum_{t=y-b}^{S_{z}-b} \frac{R_{t}}{(1+d)^{t}}
$$

where $y=1973,1979, \ldots, S_{z}$ and $d$ is the discount rate.

In the methodology adopted, the price "P" is invariant over time while the quantity of spent fuel received in the $t$-th year $\left(Q_{t}\right)$ does vary with time. Since revenue is price times quantity, Equation (1) may be written as:

$$
\sum_{t=y-b}^{S_{z}-b} \frac{c_{t}}{(1+d)^{t}}=\sum_{t=y-b}^{S_{z}-b} \frac{P_{t}}{(1+d)^{t}} \text { or } P=\sum_{t=y-b}^{S_{z}-b} \frac{{ }^{c} t}{(1+d)} / \sum_{t=y-b}^{S} \frac{a_{t}}{(1+d)^{t}}
$$

The price component $\left(P_{i}\right)$ associated with the $i$-th cost center $(i=1$, $2, \ldots, 8)$ is defined as

$$
P_{i}=\sum_{t=y-b}^{S_{z}-b} \frac{c_{i t}}{(1+d)^{t}} / \sum_{t=y-b}^{s_{z}-b} \frac{a_{t}}{(1+d)^{t}}
$$

where $C_{i t}$ is the cost incurred at the $i$-th cost center in the $t$-th year.

Note that there is no attempt to associate a particular shipment with a particular cost center. That is, every shipment has to bear a share of all costs regardless of whether that shipment utilizes the services of any particular cost renter. For example, spent fuel sent directly to a repository (thus bypassing an AFR) would still bear its share of AFR costs. Further, the price of a shipment received in the last year of a time horizon would reflect the effect of capital and 
operating costs incurred in all the previous years. Accordingly, the price component calculated does not necessarily correspond to services rendered.

\subsubsection{Procedures for Government Owned or Directly Funded Cost Centers}

As indicated in Paragraph 11.2, all costs for the categories identified above are recognized as incurred and discounted accordingly to obtain the PV of a cost center. But there also may be a closing credit (negative cost) for undepreciated capital or a closing charge for purchase of trust funds. The formulas used for each cost center are presented in Appendix $C$. Note that all cost centers are assumed to be either government owned or directly funded by the government, except for the AFRs, which arr. indirectly funded as indicated below.

\subsubsection{Procedures for Costs of Privately Owned Cost Center (AFR)}

It is assumed that the government will indirectly fund a privately owned cost center by periodic payments to the owners.

Operating and maintenance (O\&M) costs are assumed to be billed to the government on a dollar for dollar basis. The AFR 0\&M costs then become a cost to the government. There are no management fees, ${ }^{1}$ since the private operator is assumed to earn profits in the torn of return lo capital. The problem then is to formulate a procedure for calculating a schedule of government paymenls which would cnable the privatep owner to profitably recover his capital investment in an AFR.

The approach adopted was to require that the discounted sum of a series of fixed annual payments over the lifc of the AFK equals the PV of an AFR investment. Note that no AFR capital investments after start of AFR operations are required. The imputed interest rate used to calculate the PV of the AFR investment was the after tax return rate on the investment. The PV of the inves timent was then reduced by amounts sorresponding to the PV of:

- Investment tax credits (ITC)

- Accelerated depreciation tax benefits.

1 In the case of a government owned, contractor operated AFR, there would be a management fee, but there would be no private capital charges. 
In these calculations, it was assumed that the AFR venture was a subsidiary of a corporation which could fully utilize all income tax credits and that benefits flowed through the parent corporation.

Using the notation and cost center designation, 1, presented on the previous page:

$$
\text { Adjusted } \operatorname{PV}\left(C_{1}\right)=\operatorname{PV}\left(R_{1}\right)=\sum_{t=1}^{n} \frac{R_{1 t}}{(1+k)^{t}}
$$

where $k$ = private after tax discounted cash flow (DCF) return rate and $n=$ operating life of AFR.

By hypothesis, there is a level stream of revenues $\left(\bar{R}_{p}\right)$ to cover capital costs. Accordingly,

Adjusted PV $\left(C_{1}\right)=\bar{R}_{1} \sum_{t=1}^{n} \frac{1}{(1+k)^{t}}$ or $\bar{R}_{1}=\left(\sum_{t=1}^{n} \frac{1}{(1+k)^{t}}\right)^{-1}$ (Adjusted PV $\left(C_{1}\right)$ )

The inverse of the summation is a function only of $k$ and $n$ and is called the capital recovery factor or

$$
\operatorname{CRF}(k, n)=\frac{k(1+k)^{n}}{(1+k)^{n-1}}
$$

The problem then becomes one of developing a formula for the adjusted PV of the AFR investment. The approach was to divide the investment into two parts, namely:

- Depreciable investment (capital equipment and buildings)

- Non-depreciablc investment (land and working capital).

If depreciable investment costs in the $t$-th year are designated as $K_{1 t}$, the PV of depreciable investment (using the first year of beneficial use, $B_{j}$, as the base year) is equal to:

$$
\sum_{t=y-b}^{B_{1}-b} \frac{k_{1 t}}{(1+k)^{t-B_{1}+b}}=P V\left(k_{1}\right) \text { where } y \text { and } b \text { are as before }
$$

Note in the algorithms (Appendix $C$ ) that provision is made for further subscripting to allow for the presence of more than one facility. 
The PV of depreciable investments is then adjusted for the two tax benefits and the present value of property tax and insurance premiums on the value of depreciable capital. Derivations of the three adjustments follow:

a. Derivation of ITC Corrections

The tax credit law is such that a fraction, $\alpha$, of depreciable. capital can be taken as a credit as capital costs are incurred. Therefore, the PV of the credit is

$$
\sum_{t=y-b}^{B_{1}-b} \frac{a k_{1 t}}{(1+k)^{t-b_{1} \cdot b}}
$$

which is simply equal to a times the PV of depreciable capital.

b. Derivation of Depreciation Correction

Since depreciation is a book charge against taxable profits but not cash flow, the net benefits as a fraction of depreciable capital is multiplied by $\tau$, the effective federal and state income tax rate to determine the cash value of the benefit. Three modes ( $M$ ) of depreciation are permitted by the IRS, all of which are included in the formulas for $D(M)$, the depreciation factor (see Appendix $C$ ). However, unless otherwise specified, the double-the-declining balance method is used.

In this mode $(M=3)$, twice the straight line rate $\left(\frac{1}{n}\right)$ is applicable to undepreciated capital. That is, the value of the tax credits are $2 \tau / n, 2 \tau / n(1-2 / n), 2 \tau / n(1-2 / n)^{2}$... times the PV of depreciable capital. Since the benefits are received over the life of the AFR, the annual benefits must be present valued to derive the PV of the depreciation factor. Thus,

$$
U(M)=2 / n \sum_{t=0}^{n-1} \frac{(1-2 / n)^{t}}{(1+k)^{t}}=\frac{2(1+k)}{n(k+2 / n)}
$$

for the double-declining mode. 
c. Derivation of Property Tax and Insurance (Ad Valorem) Factor

The so called ad valorem charges may either be treated as an operating expense or as a capital charge. The rationale for the latter treatment is that property tax and insurance premiums can be expressed as decimal fractions $\left(\beta_{1}\right.$ and $\left.\beta_{2}\right)$ of the PV of undepreciated capital. Since these charges are tax deductible, the PV of the factor (that multiplies the PV of depreciable capital) is

$$
\sum_{t=1}^{n} \frac{(1-\tau)\left(\beta_{1}+\beta_{2}\right)}{(1+k)^{t}}=\frac{(1-\tau)\left(\beta_{1}+\beta_{2}\right)}{\operatorname{CRF}(k, n)}
$$

Finally, recall that all returns to capital are subject to income taxes at rate $\tau$. Therefore, $\tau \bar{R}_{1 k}$ (returns to depreciable capital) is subtracted from $\bar{R}_{1 k}$ the before-tax required revenue. Accordingly, substituting in (5) we have

$\bar{R}_{\mid k}-\bar{R}_{I k} \tau=\operatorname{CRF}(k, n) \operatorname{Adj} \operatorname{PV}\left(K_{j}\right)$ or $\bar{R}_{l k}=\frac{\operatorname{CRF}(k, n)}{(I-\tau)} \operatorname{Adj} \operatorname{PV}\left(K_{1}\right)$

Then substituting factors 6,7 , and 8 derived above, the required revenue to recover depreciable AFR capital is:

$$
\bar{R}_{I k}=\operatorname{PV}\left(K_{j}\right) \frac{\operatorname{CRF}(k, n)}{(1-\tau)}\left[1-\alpha-\frac{2 \tau(1+k)}{n(k+2 / n)}+\frac{(1-\tau)\left(\beta_{j}+\beta_{2}\right)}{C R F(k, n)}\right]
$$

Two aspects of Equation (1) should be noted as follows:

- Receipt of an ITC does not decrease a depreciation base, hence the depreciation base is not multiplied by $1-\alpha$.

- When the indicated multiplications are made, the ad valorem factor $\left(\beta_{1}+\beta_{2}\right)$ simply muliplies the PV of depreciable capital.

Non-depreciable capital is handled in a manner similar to depreciable capital. The PV of non-depreciable capital is the PV of land payments (the formula has the same forili as for depreciable capital) plus working capital. No return on working capital prior to operations is required since the working capital investment can be deferred until just before operations start.

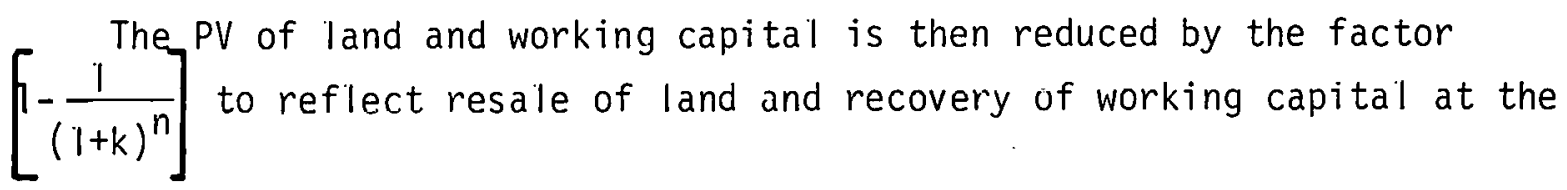


end of operations. The adjusted PV is then multiplied by $\frac{\operatorname{CRF}(k, n)}{(1-\tau)}$ to calculate the revenue required to recover land and working capital investments at the after tax rate of $k$. (Note that the property tax on land is included in 0\&M costs).

It is possible that working capital for the AFR will not be an explicit output of the cost model. Accordingly, a procedure for estimating AFR working capital is described below.

Working capital is defined by accountants as:

- Cash equivalent investments, plus inventory, plus accounts receivable, minus accounts payable.

Since AFR cash investments will probably be negligible and since the spent fuel inventory has no value, working capital can be redefined as receivables minus trade accounts payable. Since operating materials costs are expected to be very low in the AFR, a rough estimate of AFR working capital can be obtained by consideration only of accounts recelvable.

To estimate receivables, it was assumed that the government would be billed for O\&M wages and salaries and capital charge remittances to the parent corporation. The 0\&M costs are available from the cost model while an estimate of capital charges (w1 thout returns to working capital) can be made using the formulas presented above. The working capital requirement theil would be:

(Required annual revenue) $\frac{\text { (Government paytime in months) }}{12}$

For purposes of the initial price estimates, a one-month delay between billings to the government and roceipt of payments from the government was assumed. 
Unless otherwise specified, all calculations are based on use of the parameters shown in Table 11-2.

Table 11-2. Pricing Parameter Values

\begin{tabular}{|c|c|c|}
\hline Parameter & Value & Comments \\
\hline $\begin{array}{l}\text { Discount rate and government } \\
\text { interest rate. }\end{array}$ & .065 & $\begin{array}{l}\text { Average cost of U.S. debt currently } \\
\text { used in SWU discounting calculations. }\end{array}$ \\
\hline $\begin{array}{l}\text { Private unregulated after-tax } \\
\text { AFR return rate. }\end{array}$ & 0.12 & $\begin{array}{l}\text { Per } 12 / 2 / 77 \text { Oak Ridge meeting. } \\
\text { Typical return is } 0.15 \text {, but AFR has no } \\
\text { market risk. Use } 0.08 \text { (utility cost } \\
\text { of capital) if AFR utility owned. }\end{array}$ \\
\hline Effective income tax rate. & 0.50 & $\begin{array}{l}\text { Based on } .48 \text { federal and } .04 \text { state } \\
\text { rate, i.e., .48 }+.52(.04)=.50 .\end{array}$ \\
\hline Effective ITC. & 0.06 & $\begin{array}{l}\text { Based on nominal . } 10 \text { rate for equip- } \\
\text { ment corrected for the } 60 \% \text { equip- } \\
\text { ment content of an AFR. }\end{array}$ \\
\hline $\begin{array}{l}\text { Equipment and building } \\
\text { property tax rate. }\end{array}$ & 0.015 & Typical value. \\
\hline $\begin{array}{l}\text { Equipment and building } \\
\text { insurance rate. }\end{array}$ & 0.005 & Typical value. \\
\hline
\end{tabular}




\subsection{RESULTS}

This chapter presents the results of using the costs described in Chapters 3 through 8 , and the spent fuel flow scenarios described in Chapters 9 and 10, as input to the spent fuel management pricing methodology described in Chapter 11. The components of price are displayed and discussed by cost center and the components of undiscounted cost are displayed and discussed by cost center and by category. Finally, some general comparisons and interpretations are presented to put the results in perspective.

\subsection{RESULTS PRESENTATION}

Table 12-1 summarizes the one-time price of spent fuel management derived for each of the four cases defined in Chapter 10 of this study.

TABLE 12-1. Summary of Price Results

\begin{tabular}{|l|c|c|c|c|}
\hline & $\begin{array}{c}\text { Case 1 } \\
\text { High } \\
\text { Venture }\end{array}$ & $\begin{array}{c}\text { Case 2 } \\
\text { High } \\
\text { Campaign }\end{array}$ & $\begin{array}{c}\text { Case 3 } \\
\text { Low } \\
\text { Venture }\end{array}$ & $\begin{array}{c}\text { Case 4 } \\
\text { Low } \\
\text { Campaign }\end{array}$ \\
\hline \$ KGU 1 & 152.5 & 134.3 & 116.1 & 134.1 \\
Mil1s/kWhr. & .713 & .628 & .543 & .627 \\
$\begin{array}{l}\text { Cost } \\
\text { (Undiscounted } \\
\text { 1978 \$ B) }\end{array}$ & 6.290 & 7.539 & 4.093 & 3.394 \\
\hline
\end{tabular}

1 Kilograms of uranium charged initially to the reactor.

The mills per kilowait-hour shown on this chart were derived by multiplying the price in dollars per kilogram of uranium by a linear factor derived from the reactor characteristics of reference IX-1. Examination of Table 12-1 shows that the prices vary only \pm 13 percent from their midrange value. Furthermore, the effect of the timing of received fuel is evident from the fact that both the high and low extremes of price and cost occur in separate cases. The coincidence of Case 2 and Case 4 (difference 0.2 percent) illustrates high AFR expenses early to handle high flow quantities compensating for fewer later revenues with low flow quantities. 
Figure 12-1 presents the cost center components of the price results in dollars per kilogram of uranium. The values of these components can be found in Appendix B. This figure shows clearly that the AFR and the transportation cost centers of Cases 1 and 2 increase the price up to and past the values of the other cost centers in Cases 3 and 4 . Note especially that the difference between Case 1 and Case 2 is almost completely made up of the AFR cost center difference. This cost difference arose from two factors; first; the availability of the second repository's receiving capacity which allowed emptying of the AFRs two years earlier in Case 2, and second, the greater total receipts in Case 2 of which most do not. enter an AFR.

Figure 12-1 illustrates the impact of spent fuel flow quarlity and timing by highlighting the increased proportion represented by the early, fixed, costs of Research and Development on Cases 3 and 4 over Cases 1 and 2. Specifically, the fixed total R\&D costs are spread over more kilograms of spent fuel, thus resulting in lower dollars per kilogram. The increased geologic repository contribution to Case 4 over Case 3 further illustrates flow impact because the undiscounted cost center total for Case 4 is 30 percent less than for Case 3.

In order to explore the minimum price derivable from the ground rules of this study, two additional cases were calculated in which fuel was delivered to the repository at precisely the design receiving rate without AFR storage for both the venture and campaign methodologies. This receiving scenario led to an average age of fuel at placement of approximately 6 years which allowed increase of first repository capacity to 46,160 MTU. Careful phase-in of the second repository in the campaign case delayed the first repository closing two years and emplaced a total of 66,920 MTU. The results of these calculations are shown in Figures 12-? and 12-3 for the venture and campaign methodologies respectively. Note that the geologic repository, encapsulation, R\&D, and government overhead cost centers increase in both design rate cases over high flow cases, but the elimination of AFR and transportation components leads to the minimum price for this study's ground rules.

Table 12-2 shows the life cycle undiscounted cost breakdown of the four cases by cost center. All applicable categories of cost are 


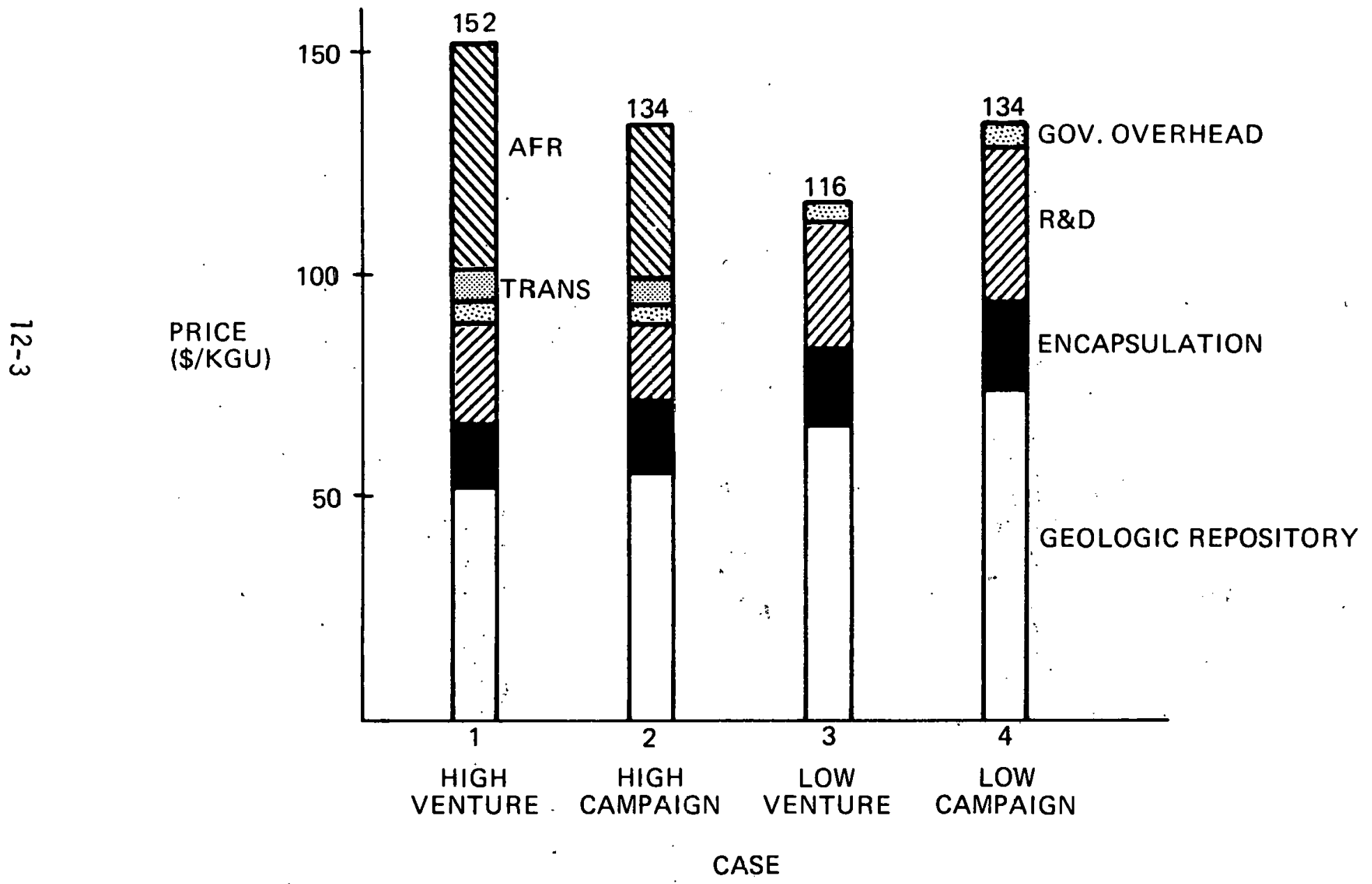

Figure 12-1. Cost Center Components of Price Results 


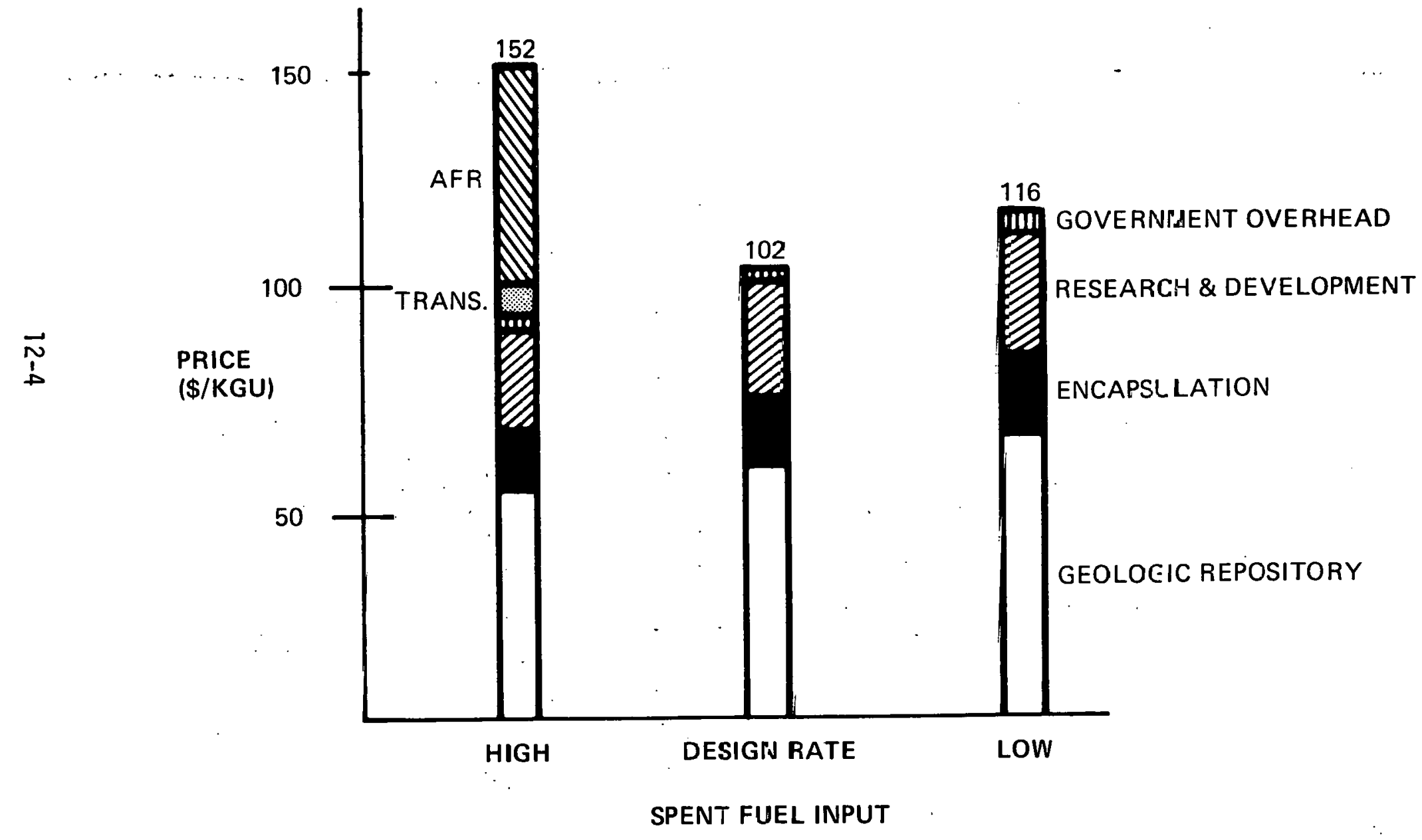

Figure 12-2. Venture Methodology Cases 


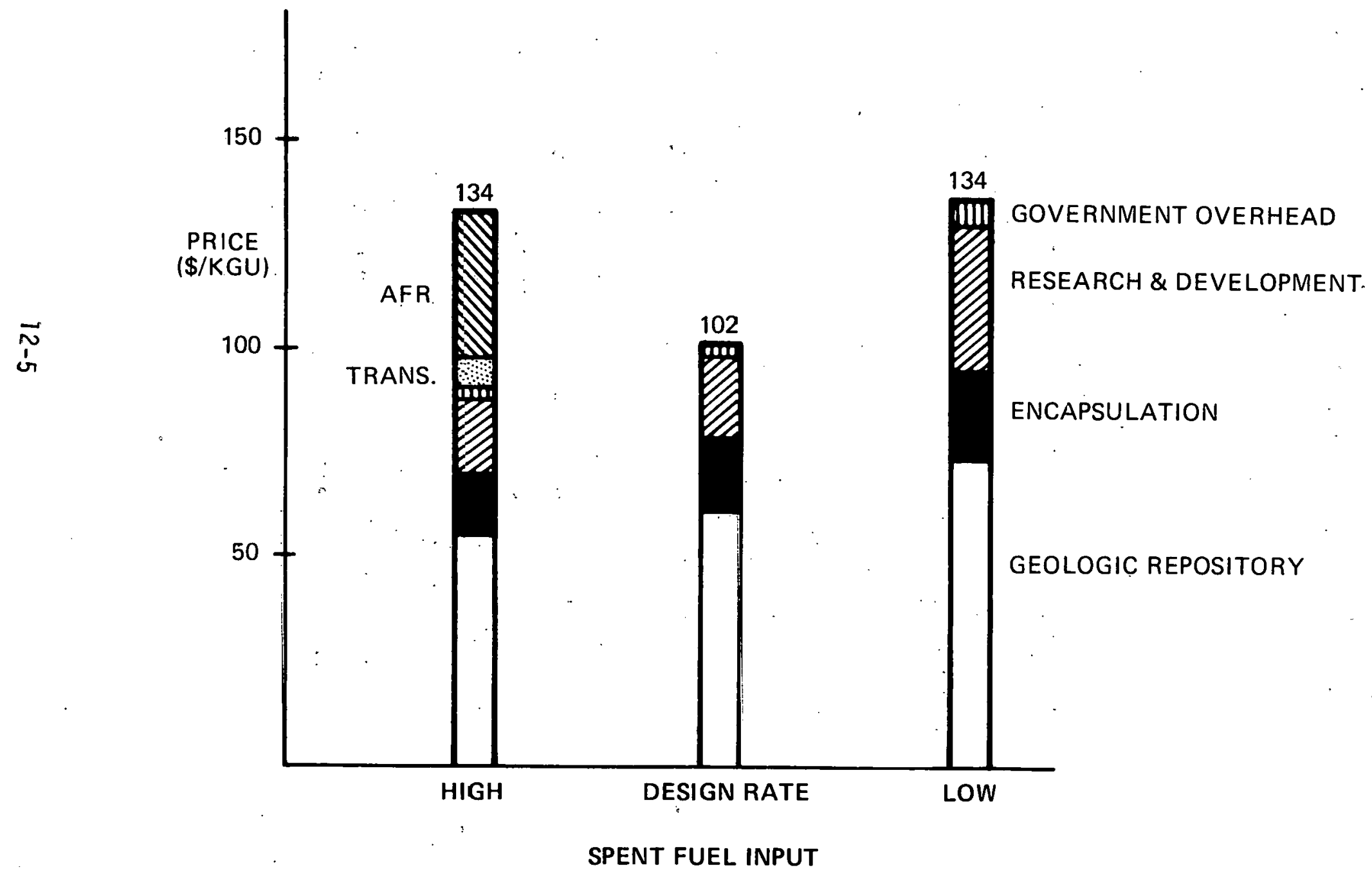

Figure 12-3. Campaign Methodology Cases 
included in each cost center's expense. This table illustrates that the dominant cost centers are the geologic repository and AFR storage which constitute between 64 and 74 percent of total cost: Details of all values shown can be found in Appendix A. Total AFR storage costs to the government are included only in Table A-6 and A-7 of Appendix $A$ because of the required translation from cost to the private operator.

TABLE 12-2. Life Cycle Cost Summary By Cost Center (Undiscounted $1978 \$ M$ )

\begin{tabular}{|l|r|r|r|c|}
\hline & $\begin{array}{c}1 \\
\text { High } \\
\text { Venture }\end{array}$ & $\begin{array}{c}\text { i } \\
\text { High } \\
\text { Campaign }\end{array}$ & $\begin{array}{c}3 \\
\text { Low } \\
\text { Venture }\end{array}$ & $\begin{array}{c}4 \\
\text { Low } \\
\text { Campaign }\end{array}$ \\
\hline Geologic Repository & 2309 & 3475 & 2755 & 2167 \\
Encapsulation & 511 & 824 & 544 & 472 \\
AFR & 2298 & 2029 & 0 & 0 \\
Transportation & 417 & 417 & 0 & 0 \\
R\&D & 560 & 560 & 560 & 560 \\
Government Overhead & 195 & 234 & 234 & 195 \\
\hline \multicolumn{1}{|c|}{ Total } & 6290 & 7539 & 4093 & 3394 \\
\hline
\end{tabular}

Table 12-3 presents the life cycle cost summary for each case by cost category. This table shows that the dominant cost category changes from capital cost in Cases 1 and 2 to 0\&M cost in Cases 3 and 4 . The category "Other" contains the sum of transportation, R\&D, and government overhead costs. Note that al though trust fund costs constitute between 8 and 13 percent of undiscounted cost, their very late occurrence constitutes only 3.5.to 5.5 percent of the price of spent fuel management. Detailed cross references of cost center to category cost for each case will be found in Appendix A. 
TABLE 12-3. Life Cycle cost Summary By Category

(Undiscounted 1978 \$M)

\begin{tabular}{|l|c|c|c|c|}
\hline & $\begin{array}{c}1 \\
\text { High } \\
\text { Venture }\end{array}$ & $\begin{array}{c}2 \\
\text { High } \\
\text { Campaign }\end{array}$ & $\begin{array}{c}3 \\
\text { Low } \\
\text { Venture }\end{array}$ & $\begin{array}{c}4 \\
\text { Low } \\
\text { Campaign }\end{array}$ \\
\hline Capital & 2980 & 3354 & 886 & 886 \\
O\&M & 1560 & 2327 & 1879 & 1485 \\
Trust Funds & 578 & 647 & 534 & 268 \\
Other & 1172 & 1211 & 794 & 755 \\
\hline \multicolumn{1}{|c|}{ Total } & 6290 & 7539 & 4093 & 3394 \\
\hline
\end{tabular}

\subsubsection{PRICE INTERPRETATIONS}

Figure 12-4 illustrates the comparison of Case 2 price to those of other nuclear fuel cycle components as estimated in reference XII-1. Prices illustrated represent average 1985 values of a 1200 MWe PWR with startup in 1982, in 1976 dollars. The spent fuel management charge falls below the average of these costs but above the lowest value. Therefore, the spent fuel management price is comparable to those of other fuel cycle components. It is, however, an additional cost component which increases the total fuel cycle price. A number of conservative assumptions have been included, contingency funds have been provided, and the system parameters, although reasonable, are not optimized. Therefore, the absolute level of the spent fuel management prices presented in this study are defensible as accurate within the estimate error of the cost estimates (maximum \pm 30 percent).

The sensitivity of these prices is quite low, only \pm 13 percent from their mid-range value even though costs vary \pm 38 percent, and receipts \pm 28 percent from their mid-range value. This insensitivity results from colipensating factors which return prices to the observed

Includes AFR operator return, taxes, and insurance. 


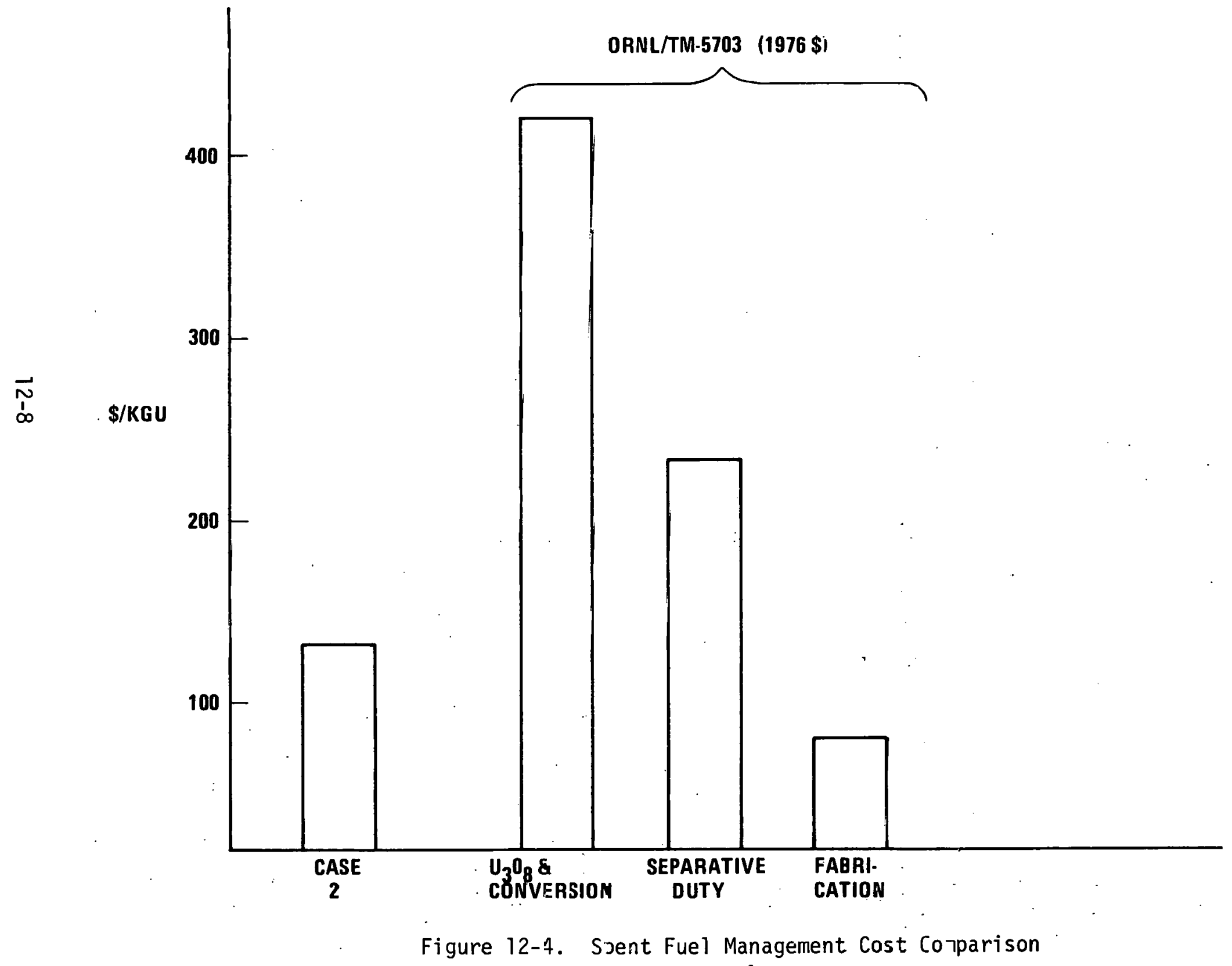


range. These include additional cost centers (AFR and Transportation) for high early receipts versus less revenues for low receipts. Even the optimum flow of spent fuel price has been shown to be only 24 percent below the four case mid-range value.

Several additional topical concerns which could not be investigated within the resources of this study may cause more sensitivity in price than observed here. These include:

- Other media besides salt which impacts capital cost and capacity of the repository.

- First repository start date which impacts the quantity of A.FR storage required and, therefore, AFR charges to the government.

- Government ownership of AFR storage which reduces costs because of the different cost recovery methodologies.

- Long term AFR utilization which allows accepting additional fuel at minimum cost.

- Cask flow constraints which delay AFR closing and transportation costs.

- Government cask ownership which reduces transportation. cost because of the different cost.recovery methodologies.

- Second repository start date considerations.

- Methods to recompute price in the presence of changes.

- Additional parametric variations such as capital cost, capacity, and desion receipt rate may show additional sensitivity highlights of interest.

- Less than indefinite retrievability which reduces 0\&M costs and increases repository capacity. 


\section{BIBLIOGRAPHY}

REFERENCE NO.

III-1 "OWI Revisions to Kaiser Engineer's preliminary submissions," Jan. 1978.

III-2 Preliminary graph of MTHM/Acre Versus Years After Discharge, OWI-78-1, Jan. 5, 1978, J. E. Russe11.

III-3 S.C. Matthews notes of 0ct. 10, 1977 revising Kaiser Engineer's base estimates.

III-4 "Spent Fuel Repository Cost Estimates," letter of C.D. Zerby, Director, Office of Waste Isolation to J. J. Schreiber, Director, Division of Waste Management, DOE, Oak Ridge Operations, Jan. 6, 1978

III-5 "Capital Cost Estimate and Construction Impacts, Geologic Isolation and Disposal, Reference Facility 20-58a, Isolation in Bedded Salt, $U$ and Pu Recycle," Report 20-58a, Revision 1, Sept. 21, 1977, Bechtel, Inc., Job No: 12106 for Batelle'Pacific Northwest Laboratories.

II -6 "Prel iminary Estimates for Repository Scenarios Requested by DOE Waste Management Policy Committee," letter from C. D. Zerby, Director, Office of Waste Isolation to J. J. Schreiber, Director, Division of Waste Management, DOE, Oak Ridge Operations, Jan. $16,1978$.

IV-1 "Capital Cost Estimate and Construction Impacts, Spent Fuel. Interim Storage Reference Facility 18-53, Spent Fuel Packaging," Final Report 18-53, Aug. 19, 1977, Bechtel, Inc., Job No. 12106 for Battelle Pacific Northwest Laboratories.

IV-2 "Capital Cost Estimale and Construction Impacts, Spent Fuel Interim Storage Reference Facility 18-54, Water Basin Storage of Packaged Fuel," Final Report 18-54, Aug. 23, 1977, Bechtel, Inc. Job No. 12106 for Battelle Pacific Northwest Laboratories.

V-1 Briefing of DuPont Savannah River Operations Advanced Operational Planning Department to DOE Headquarters personne1, Dec. 21, 1977.

V-2 Excerpts of "Regional Nuclear Fuel Cycle Centers," Vol. I Summary, Vol. II Basic Studies, 1977 report of the International Atomic Energy Agency. 
REFERENCE NO.

V-3 "Capital Cost Estimate and Construction Impacts, Spent Fuel Interim Storage Reference Facilities 18-52a and 18-52b, Water Basin Storage of Unpackaged Fue1," Draft Report 18-52a, Aug. 15, 1977, Bechtel, Inc., Job No. 12106 for Battelle Pacific Northwest Laboratories

VI-1 "Transportation/Logistics Study," OWI memo from L.B. Shappert to D.W. Turner, Dec. 5, 1977.

VII-1 "R\&D Costs for Encapsulation and Geologic Storage of Spent Fuel from Commercial Power Reactors," Draft Memo from G.W. Cunningham, Acting Program Director for Nuclear Energy, to John D. Young, Acting Comptroller, date of draft Dec. 19, 1977.

VIII-1 Briefing of DOE URE personne1, Dec. 13, 1977.

IX-1 Projections of Spent Fuel to be Discharged by the U.S. Nuclear Power Industry, C. W. Kee, C. W. Alexander, and J. 0. Blomeke, Draft Report ORNL/TM-6008, Ju1y 27, 1977.

IX-2 "Reactor Discharge Schedules (Metric Turls of Heavy Metal)," DOE Headquarters, Jan. 3, 1978 viewgraph for presentation to the Waste Management Task Force.

XI-1 "Cost Center Breakdown for OWI Economic Study," TRW Internal-Office Correspondence, J.D. Forster, Jan. 19, 1978.

XI-2 Federal Register Notice 38 FR 12180, May 9, 1973.

XII-1 A Survey of Nuclear Fuel Cycle Economics: 1970-1985, URNL/IM-5703, B. E. Prince, J. F. Pecrenboom, J.G. Delene, March 1977. 


\section{APPENDIX A. DETAILED COST RESULTS}

This Appendix presents the detailed undiscounted costs for each case examined in this study. The assumptions and data sources which support these data are enumerated in the body of this report.

Table A-l summarizes the major inputs and outputs of all four cases including discounted values. Note especially the impact of timing shown by the relationships of undiscounted range of variation to discounted range of variation in both the costs and the receipts.

Tables A-2 through 5 show the detailed costs by year for all elements of the four study cases. Note that these costs do not add to the undiscounted costs shown in Table A-1 in Cases 1 and 2 because they exclude AFR operator's return, taxes, and insurance.

Tables A-6 through A-9 show the cross reference of cost center to cost category expenditures for the four cases. From these values are those of Tables A-2 and A-3, undiscounted AFR operator's return, taxes, and insurance (included in Tables A-6 and A-7) can be calculated to be $\$ 1526 M(1978)$ in Case 1 and $\$ 1280 M(1978)$ in Case 2. Capital cost totals in all tables involving Cases 2. and 4 include ending undepreciated value of still available facilities.

Table A-10 displays the contingency funds provided in each case. Both capital and post operation contingencies are included. No additional contingency has been added after the present value calculation in contrast to the final 15 percent contingency included in uranium enrichment price calculation.

Table A-11 displays the annual capitalization charges resulting from Chapter 11 methodology applied to each AFR. Note that although the charge increases for shorter life spans, the increase is not large enough to result in greater total charges to the government for less active 1 ife. 
TARLE A-1. DETAILED DA-A SUMMARY

\begin{tabular}{|c|c|c|c|c|}
\hline $\begin{array}{l}\text { CASE NO. } \\
\text { FLOW RATE } \\
\text { CLOSING METHOD }\end{array}$ & $\begin{array}{c}1 \\
\text { HIGH } \\
\text { VENTURE }\end{array}$ & $\begin{array}{c}2 \\
\text { HIGH } \\
\text { CAMPAIGN }\end{array}$ & $\begin{array}{c}3 \\
\text { LOW } \\
\text { VENTIJRE }\end{array}$ & $\begin{array}{c}4 \\
\text { LOW } \\
\text { CAMPAIGN }\end{array}$ \\
\hline $\begin{array}{l}\text { PRICE } \\
\qquad / K^{\top}{ }^{7} \\
\text { MILLS/KWHR }^{2}\end{array}$ & $\begin{array}{r}152.5 \\
.7132 \\
\end{array}$ & $\begin{array}{r}134.3 \\
.6279 \\
\end{array}$ & $\begin{array}{r}116.1 \\
.5430 \\
\end{array}$ & $\begin{array}{r}134.1 \\
.6270 \\
\end{array}$ \\
\hline $\begin{array}{l}\text { COST }(\$ B) \\
\text { UNDISCOUNTED } 1978 \\
\text { DISCOUNTED }\end{array}$ & $\begin{array}{l}6.290 \\
3.220 \\
\end{array}$ & $\begin{array}{l}7.539 \\
3.738 \\
\end{array}$ & $\begin{array}{l}4.093 \\
2.011 \\
\end{array}$ & $\begin{array}{l}3.394 \\
1.904 \\
\end{array}$ \\
\hline $\begin{array}{l}\text { RECEIPT (MTU) }{ }^{1} \\
\text { UNDISCOUNTED } \\
\text { DISCOUNTED } \\
\end{array}$ & $\begin{array}{l}44,200 \\
21,114 \\
\end{array}$ & $\begin{array}{r}68,510 \\
27,837 \\
\end{array}$ & $\begin{array}{l}52,500 \\
17,317 \\
\end{array}$ & $\begin{array}{l}38,420 \\
14,197 \\
\end{array}$ \\
\hline $\begin{array}{l}\text { CLOSING YEAR } \\
\text { FIRST REPOSITORY } \\
\text { SECOND REPOSITJRY } \\
\text { SCENARIO }\end{array}$ & $\begin{array}{r}1997 \\
N / A \\
1997 \\
\end{array}$ & $\begin{array}{l}1998 \\
2011 \\
2000 \\
\end{array}$ & $\begin{array}{r}2003 \\
N / A \\
2003 \\
\end{array}$ & $\begin{array}{l}2005 \\
2022 \\
2000 \\
\end{array}$ \\
\hline
\end{tabular}

1 Initially charged to the reactor.

2 Linear multiple of \$/KGU using Reference IX-I factors. 
TABLE A-2. DETAILED COST INPUTS - CASE 1

HIGH FLOW RATE, VENTURE METHODOLOGY $1978 \$, M$

\begin{tabular}{|c|c|c|c|c|c|c|c|c|c|c|c|c|c|c|c|c|c|c|c|c|c|c|c|c|c|c|c|c|}
\hline CATEGORY & TOTAL & 1978 & 1979 & 1980 & \begin{tabular}{|l|l}
1981 & 1 \\
1
\end{tabular} & 1982 & 1983 & 1984 & 1985 & 1986 & 1987 & 1988 & 1989 & 1990 & 1991 & 1992 & 1993 & 1994 & 1995 & 1996 & 1997 & 1998 & 1999 & 2000 & 2001 & 2002 & 2003 & $\begin{array}{l}\text { ENDING } \\
\text { VALUEE }\end{array}$ \\
\hline $\begin{array}{l}\text { SPENT FUEL FLOW } \\
\text { ANNUAL RECEIPTS } \\
\text { ACCUMULATION } \\
\text { AFR CONTENTS } \\
\text { AFR SHIPMENTS }\end{array}$ & $\begin{array}{l}44200 \\
N / A \\
12860 \\
12860\end{array}$ & & & & & & $\begin{array}{l}2000 \\
2000 \\
2000\end{array}$ & {$\left[\begin{array}{l}2000 \\
4000 \\
4000\end{array}\right.$} & $\mid \begin{array}{l}3020 \\
7020 \\
7000\end{array}$ & $\begin{array}{c}3210 \\
10230 \\
8430\end{array}$ & \begin{tabular}{|c|c}
3260 \\
13490 \\
9910
\end{tabular} \mid & $\begin{array}{r}2390 \\
15880 \\
10520\end{array}$ & $\left|\begin{array}{r}2780 \\
18660 \\
11520\end{array}\right| \begin{array}{l}2 \\
1\end{array}$ & $\begin{array}{r}3120 \\
21780 \\
12860\end{array}$ & $\begin{array}{r}3040 \\
24820 \\
10580 \\
2280\end{array} \mid 2$ & $\left|\begin{array}{l}3450 \\
28270 \\
8710 \\
1870\end{array}\right|$ & $\begin{array}{r}3790 \\
32060 \\
7180 \\
1530\end{array}$ & $\begin{array}{r}4120 \\
36180 \\
5980 \\
1200\end{array} \mid$ & $\left|\begin{array}{r}4440 \\
40620 \\
5100 \\
880\end{array}\right|$ & $\begin{array}{r}3580 \\
44200 \\
3360 \\
1740 \\
\end{array}$ & $\begin{array}{r}0 \\
44200 \\
0 \\
3360\end{array}$ & & & & & & & \\
\hline $\begin{array}{l}\text { COSTS } \\
\text { RESEARCH \& DEVELOPMENT } \\
\text { BEFORE } 78 \\
\text { ANNUAL R\&D }\end{array}$ & $\begin{array}{c}(560.0) \\
40.1 \\
519.9 \\
\end{array}$ & 86.1. & 120.1 & 97.8 & \begin{tabular}{|c|}
93.4 \\
\end{tabular} & 76.1 & 27.5 & 9.4 & 5.8 & 3.7 & & & & & & & & & & & & -1 & & & . & & & \\
\hline GOVERNMENT OVERHEAD & 195. & & & & & & 13.0 & 13.0 & 13.0 & 13,0 & 13.0 & $13.0^{\circ}$ & 13.0 & 13.0 & 13,0 & 13,0 & 13.0 & 13.0 & 13.0 & 13.0 & 13,0 & 1 & & & & & & \\
\hline TRANSPORTATION & 417.155 & & & & & & & & & & & & & & \begin{tabular}{l|l}
73.96 & 1 \\
\end{tabular} & 60.66 & 49.63 & \begin{tabular}{|l|l|}
38.926 \\
\end{tabular} & \begin{tabular}{|l|}
28.545 \\
\end{tabular} & \begin{tabular}{|l|l|}
56.442 \\
\end{tabular} & 108.992 & $T$ & & & & & & \\
\hline $\begin{array}{l}\text { ENCAPSULATION } \\
\text { \#I CAPITAL } \\
\text { OPS. \& MAINT. } \\
\text { OECOMMISSIONING } \\
\text { \#2 CAPITAL } \\
\text { OPS. \& MAINT. } \\
\text { DECOMMISSIONING }\end{array}$ & $\begin{array}{c}(508.98) \\
287.6 \\
201.44 \\
19.94\end{array}$ & & & & 20.6 & 65.7 & 87.4 & 92.1 & $\begin{array}{l}21.8 \\
.09\end{array}$ & 8.53 & 8.53 & 8.53 & 8.53 & 8.53 & 23.022 & 23.02 & 23.02 & 23.02 & 23.02 & 23.02 & $\begin{array}{l}20.58 \\
19.94\end{array}$ & 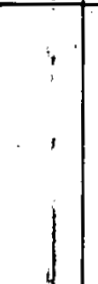 & & & & & & \\
\hline $\begin{array}{l}\text { GEOLOGIC REPOSITORY } \\
\text { \#1 CAPITAL } \\
\text { OPS. \& MAINT. } \\
\text { OPECOMMISSIONING } \\
\text { POST OPS. } \\
\text { \#2 CAAPITAL } \\
\text { OPS. \& MAINT. } \\
\text { OECOMMISSIONING } \\
\text { POST OPS. }\end{array}$ & $\left(\begin{array}{c}(2309.153) \\
596.0 \\
1199.208 \\
156.56 \\
357.385\end{array}\right)$ & 0.35 & $2.682^{2}-2-2$ & 22.68 & $90.77 \mid 1$ & 146.9 & $|132.86| 1$ & 104.95 & $\mid \begin{array}{c}94.81 \\
.77\end{array}$ & 77.2 & 78.14 & \begin{tabular}{|l|l|}
78.4 & -4 \\
\end{tabular} & $77.64 \mid 7-20$ & 78.08 & $|127.02|^{1}$ & $120.14 / 1$ & $|112.27| 1$ & \begin{tabular}{|l|l|l}
113.78 & 1 \\
\end{tabular} & $|25.87|_{1}^{1}$ & 116.548 & $\begin{array}{c}93.35 \\
156.56 \\
357.385\end{array}$ & & & & & & & \\
\hline $\begin{array}{l}\text { AFR STORAGE } 1 \\
\text { \#1 CAPITAL } \\
\text { LAND } \\
\text { WORKING CAPITAL } \\
\text { OPS. \& MAINT. } \\
\text { DECOMMISSIONING } \\
\text { \#2 CAPITAL } \\
\text { LAND } \\
\text { WORKING CAPITAL } \\
\text { OPS. \& MANT. } \\
\text { DECOMMISSIONING }\end{array}$ & $\begin{array}{c}(780.67) \\
273 . \\
5 . \\
6.19 \\
82 . \\
22.07 \\
273 . \\
5 . \\
6.34 \\
78 . \\
22.07\end{array}$ & & $\begin{array}{c}15 . \\
3 .\end{array}$ & $\begin{array}{r}34 . \\
2 .\end{array}$ & $\begin{array}{c}15 \\
3\end{array}$ & $\begin{array}{c}34 \\
2\end{array}$ & $\begin{array}{c}6.19 \\
6 \\
111 .\end{array}$ & $\begin{array}{c}6 \\
113\end{array}$ & $\begin{array}{c}6.34 \\
6\end{array}$ & 6 & 4 & 4 & 4 & 4 & 6 & 6 & 6 & 6 & . & 6 & $\begin{array}{l}6 \\
22.07 \\
\therefore\end{array}$ & $i$ & & & & & & \\
\hline
\end{tabular}


TABLE A-3. DETAILED COST INPUTS - CASE 2

HIGH FLOW RATE, CAMIPAIGN METHODOLOGY

1978 \& M

\begin{tabular}{|c|c|c|c|c|c|c|c|c|c|c|c|c|c|c|c|c|c|c|c|c|c|c|c|c|c|c|c|c|}
\hline $\begin{array}{c}\text { YEAR } \\
\text { CATEGORY } \\
\end{array}$ & TOTAL & 1978 & 1979 & 1980 & 1981 & 1982 & 1983 & 1984 & 1985 & 1986 & 1987 & 1988 & 1989 & $\begin{array}{l}1 \\
1990 \\
\end{array}$ & 1991 & 1992 & 1993 & 1994 & 1995 & 1996 & 1997 & 1998 & 1999 & 2000 & 2001 & 2002 & 2003 & $\begin{array}{l}\text { ENDING } \\
\text { VALUE } \\
\end{array}$ \\
\hline $\begin{array}{l}\text { SPENT FUEL FLOW } \\
\text { ANNUAL RECEIPTS } \\
\text { ACCUMULATION } \\
\text { AFR CONTENTS } \\
\text { AFR SHIPMENTS }\end{array}$ & $\begin{array}{l}68510 \\
\text { N/A } \\
12860 \\
12860\end{array}$ & & & & & & $\begin{array}{l}2000 \\
2000 \\
2000\end{array}$ & $\begin{array}{l}2000 \\
4000 \\
4000\end{array}$ & $\begin{array}{l}3020 \\
7020 \\
7000\end{array}$ & $\begin{array}{r}3210 \\
10230 \\
8430\end{array}$ & \begin{tabular}{rl|}
3260 \\
13490 \\
9910
\end{tabular} & $\begin{aligned} 2390 \\
15880 \\
10520\end{aligned} \mid$ & $\begin{array}{rl}2780 & 27660 \\
18620 & 2\end{array}$ & $\begin{array}{r}3120 \\
21780 \\
12860\end{array} \mid$ & $\begin{array}{r}3040 \\
24820 \\
10580 \\
2280\end{array}$ & $\left|\begin{array}{l}3450 \\
28270 \\
8710 \\
1870\end{array}\right|$ & $\begin{array}{r}3790 \\
32060 \\
7180 \\
1530\end{array}$ & $\begin{array}{r}4120 \\
36180 \\
3180 \\
4000\end{array}$ & $\begin{array}{r}4440 \\
40620 \\
0 \\
3180\end{array}$ & $\begin{array}{r}4800 \\
45420\end{array}$ & $\begin{array}{r}5170 \\
50590\end{array}$ & $\begin{array}{r}5560 \\
56150\end{array}$ & $\begin{array}{r}5970 \\
62120\end{array}$ & $\begin{array}{r}6390 \\
68510\end{array}$ & & & & \\
\hline $\begin{array}{l}\text { COSTS } \\
\text { RESEARCH \& DEVELOPMENT } \\
\text { BEFORE } 78 \\
\text { ANNUAL R\&D }\end{array}$ & $\begin{array}{l}(560.0) \\
40.1 \\
5199\end{array}$ & 86.1 & $12 n .1$ & \begin{tabular}{|l|}
97.8 \\
\end{tabular} & 93,4 & 78.1 & 27.5 & 9.4 & 5.8 & 3.7 & & & & & & & & & & & & & & & & & & \\
\hline GUVERNMENT OVER̈HEAD & 234. & & & & & & 13.0 & 13.0 & 13.0 & 13.0 & 13.0 & 13.0 & 13.0 & 13.0 & 13.0 & 13.0 & 13.0 & 13.0 & 13.0 & 13.0 & 13.0 & 13.0 & 13.0 & 13.0 & & & & \\
\hline TRANSPORTATION & 417.15 & & & & & & & & & & & & & & 73.96 & 60.66 & 49.63 & 129.75 & 103.15 & & & & & & & & & \\
\hline $\begin{array}{l}\text { ENCAPSULATION } \\
\text { \#1 CAPITAL } \\
\text { OPS. \& MAINT. } \\
\text { DECOMMISSIONING } \\
\text { \#2 CAPITAL } \\
\text { OPS. \& MAINT. } \\
\text { DECOMMISSIONING } \\
\end{array}$ & $\begin{array}{c}(819.822) \\
287.6 \\
195.94 \\
19.94 \\
200.72 \\
113.04 \\
2.582 \\
\end{array}$ & & & & 20.6 & 65.7 & 87.4 & 92.1 & $\begin{array}{l}21.8 \\
.09\end{array}$ & 8.53 & 8.53 & 8.53 & $\begin{array}{l}8.53 \\
20.6\end{array}$ & $\begin{array}{l}8.53 \\
65.7\end{array}$ & $\begin{array}{r}23.02 \\
87.4\end{array}$ & 23.02 & $\begin{array}{l}23.02 \\
21.8\end{array}$ & $\begin{array}{l}23.02 \\
13.16\end{array}$ & $\begin{array}{l}23.02 \\
12.52\end{array}$ & $\begin{array}{l}13.46 \\
11.85\end{array}$ & $\begin{array}{l}13.46 \\
12.27\end{array}$ & $\begin{array}{l}11.18 \\
19.94 \\
13.42\end{array}$ & 23.81 & $\begin{array}{l}26.01 \\
2.582\end{array}$ & & & & 86.88 \\
\hline $\begin{array}{l}\text { GEOLOGIC REPOSITORY } \\
\text { \#1 CAPITAL } \\
\text { OPS. \& MAINT. } \\
\text { DECOMMISSIONING } \\
\text { POSII OFH. } \\
\text { \#2 CAPITAL } \\
\text { OPS. \& MAINT. } \\
\text { DFCOMMISSIONING } \\
\text { POST OPS. }\end{array}$ & $\mid \begin{array}{c}(3475.109) \\
596.0 \\
1265.839 \\
156.56 \\
357.385 \\
417.2 \\
615.582 \\
20.26 \\
46.283\end{array}$ & 0.35 & 2.68 & 22.68 & 90.77 & 146.9 & $\mid 132.86$ & $104.95 \mid$ & $\begin{array}{c}94.81 \\
.77\end{array}$ & .35 & 2.68 & 22.68 & 90.77 & 146.9 & 132.86 & 104.95 & 94.81 & 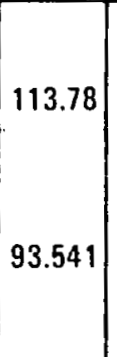 & 87.05 & 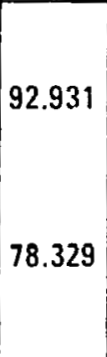 & $\begin{array}{r}90.089 \\
82.438\end{array}$ & $\begin{array}{r}93.509 \\
150.58 \\
357.585 \\
\\
95.428\end{array}$ & 92.292 & $\begin{array}{c}86.504 \\
20.26 \\
46.283\end{array}$ & & & & 178.8 \\
\hline $\begin{array}{l}\text { AFR STORAGE } 1 \\
\text { \#1 CAPITAL } \\
\text { LAND } \\
\text { WORKING CAPITAL } \\
\text { OOS. \& MAINT. } \\
\text { DECOMMISIONING } \\
\text { \#2 CAPITAL } \\
\text { LAND } \\
\text { WORKING CAPITAL } \\
\text { OPE. \& MAINT. } \\
\text { DECOMMISSIONING }\end{array}$ & $\begin{array}{c}(749.06) \\
273 . \\
5 . \\
6.34 \\
70 . \\
22.07 \\
27.3 \\
5 . \\
6.58 \\
88 \\
22.07\end{array}$ & & $\begin{array}{r}15 . \\
3 .\end{array}$ & $\begin{array}{r}34 . \\
2 .\end{array}$ & $\begin{array}{c}15 . \\
3\end{array}$ & 34. & $\begin{array}{c}6.34 \\
6 \\
111 .\end{array}$ & $\begin{array}{c}6 \\
113 .\end{array}$ & $\begin{array}{c}6.58 \\
6\end{array}$ & 6 & 4 & 4 & 4 & 4 & 6 & i & f & B & 22.07 & & & & & & & & & \\
\hline
\end{tabular}

${ }^{1}$ AFR Operator's C.ost - Excludes Return, Taxcs, and Insurance. 
TABLE A-4. DETAILED COST INPUTS - CASE 3

LOW FLOW RATE - VENTURE METHCDOLOGY

\begin{tabular}{|c|c|c|c|c|c|c|c|c|c|c|c|c|c|c|c|c|c|c|c|c|c|c|c|c|c|c|c|c|}
\hline CATEGORY & TOTAL & 1978 & 1979 & 1980 & 1981 & 1982 & \begin{tabular}{|l|l}
1983 & 1 \\
\end{tabular} & 1984 & 1985 & 1986 & \begin{tabular}{|l|}
1987 \\
\end{tabular} & 1988 & 1989 & 1990 & 1991 & \begin{tabular}{|l|}
1992 \\
\end{tabular} & $\mid$\begin{tabular}{|l|} 
\\
\end{tabular} & 1994 & 1995 & 1996 & 1997 & 1998 & 1999 & 2000 & 2001 & 2002 & 2003 & $\begin{array}{l}\text { ENDING } \\
\text { VALUE }\end{array}$ \\
\hline $\begin{array}{l}\text { SPENT FUEL FLOW } \\
\text { ANNUAL RECEIPTS } \\
\text { ACCUMULATION } \\
\text { AFR CONTENTS } \\
\text { AFR SHIPMENTS } \\
\end{array}$ & $\begin{array}{l}52500 \\
N / A\end{array}$ & 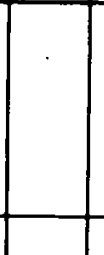 & 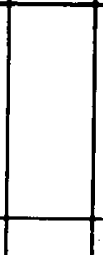 & . & . & 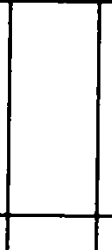 & & 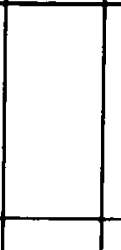 & $\begin{array}{l}20 \\
20\end{array}$ & $\begin{array}{l}1780 \\
1800\end{array}$ & $\begin{array}{l}1780 \\
3580\end{array}$ & $\begin{array}{l}1780 \\
5360\end{array} \mid$ & $\begin{array}{l}1780 \\
7140\end{array}$ & $\begin{array}{l}1780 \\
8920\end{array}$ & $\begin{array}{r}1980 \\
10900\end{array} \mid$ & $\left|\begin{array}{r|r}1790 \\
12690\end{array}\right| 1$ & $\begin{array}{r}1990 \\
14680\end{array}$ & $\begin{array}{r}2280 \\
16960\end{array}$ & $\begin{array}{r}2620 \\
19580\end{array}$ & $\begin{array}{r}3040 \\
22620\end{array}$ & $\begin{array}{r}3450 \\
26070\end{array}$ & $\begin{array}{r}3790 \\
29860\end{array}$ & $\begin{array}{r}4120 \\
33980\end{array}$ & $\begin{array}{l}? .4440 \\
38420 \\
?\end{array}$ & $\begin{array}{r}4800 \\
43220\end{array}$ & $\begin{array}{r}5170 \\
48390\end{array}$ & $\begin{array}{r}4110 \\
52500\end{array}$ & \\
\hline $\begin{array}{l}\text { COSTS } \\
\text { RESEARCH \& DEVELOPMENT } \\
\text { BEFORE 78 } \\
\text { ANNUAL R\&D } \\
\end{array}$ & \begin{tabular}{|c|}
$(560.0)$ \\
40.1 \\
519.9 \\
\end{tabular} & 86.1 & 120.1 & $\begin{array}{l}97.8 \\
\end{array}$ & \begin{tabular}{|l|l}
93.4 \\
\end{tabular} & 76.1 & 27.5 & 9.4 & 5.8 & 3.7 & & & & & & & & & & & & & & 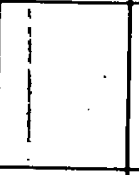 & & & & \\
\hline GOVERNMENT OVERHEAD. & 234. & & & & & & & & & 13.0 & 13.0 & 13.0 & 13.0 & 13.0 & 13.0 & 13.0 & \begin{tabular}{|l|l|}
13.0 \\
\end{tabular} & 13.0 & 13.0 & 13.0 & 13.0 & 13.0 & 13.0 & 13.0 & 13.0 & 13.0 & 13.0 & \\
\hline $\begin{array}{l}\text { TRANSPORTATION } \\
\text { ENCAPSULATION }\end{array}$ & & & & & & & & & & & & & & & & & & & & & & & & 7 & & & & \\
\hline $\begin{array}{l}\text { ENCAPSULATION } \\
\text { \#1 CAPITAL } \\
\text { OPS. \& MAINT. } \\
\text { DECOMMISSIONINE } \\
\text { \#2 CAPITAL } \\
\text { OPS. \& MAINT. } \\
\text { DECOMMISSIONING } \\
\end{array}$ & $\begin{array}{c}(541.48) \\
287.6 \\
234.44 \\
19.94\end{array}$ & & & & 20.6 & $\mid 65.7$ & 87.4 & 92.1 & $\begin{array}{c}21.8 \\
.09\end{array}$ & 8.53 & 8.53 & \begin{tabular}{|l|} 
\\
\end{tabular} & 8.53 & 8.53 & 8.78 & 8.54 & 8.79 & 10.83 & \begin{tabular}{|l|}
11.25 \\
\end{tabular} & 13.45 & 15.64 & 16.07 & 18.16 & $\begin{array}{l}18.55 \\
.11 \\
11 \\
3 \\
\end{array}$ & 20.68 & 21.14 & $\begin{array}{l}19.82 \\
19.94\end{array}$ & \\
\hline $\begin{array}{l}\text { AFR STORAGE } \\
\text { \#1 CAPITAL } \\
\text { LAND } \\
\text { WORKING CAPITAL } \\
\text { OPS. \& MAINT. } \\
\text { DECOMMISSIONING } \\
\text { \#2 CAPITAL } \\
\text { LAND } \\
\text { WORKING CAPITAL } \\
\text { OPS. \& MAINT. } \\
\text { OECOMMISSIONING }\end{array}$ & & & & & & & & & & & & & & & & & & & & & & & & 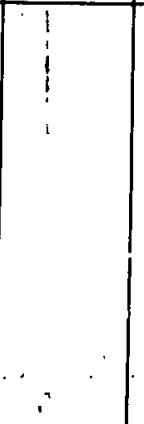 & & * & & . \\
\hline
\end{tabular}


TABLE A-5. DETAILED COST INPUT - CASE 4

LOW FLOW RATE CAMPAIGN METHODOLOGY

1978 \& $M$

\begin{tabular}{|c|c|c|c|c|c|c|c|c|c|c|c|c|c|c|c|c|c|c|c|c|c|c|c|c|c|c|c|c|}
\hline CATEGORY & TOTAL & 1978 & 1979 & 1980 & 1981 & 1982 & 1983 & 1984 & 1985 & 1986 & 1987 & 1988 & 1989 & 1990 & 1991 & 1992 & 1993 & 1994 & 1995 & 1996 & 1997 & 1998 & 1999 & 2000 & 2001 & 2002 & 2003 & $\begin{array}{l}\text { ENDING } \\
\text { VALUE }\end{array}$ \\
\hline $\begin{array}{l}\text { SPENT FUEL FLOW } \\
\text { ANNUAL RECEIPTS } \\
\text { ACCUMULATION } \\
\text { AFR CONTENTS } \\
\text { AFR SHIPMENTS }\end{array}$ & $\begin{array}{c}38420 \\
\text { N/A }\end{array}$ & & & & & & & & $\begin{array}{l}20 \\
20\end{array}$ & $\begin{array}{l}1780 \\
1800\end{array}$ & $\left|\begin{array}{l}1780 \\
3580\end{array}\right|$ & $\left|\begin{array}{l}1780 \\
5360\end{array}\right|$ & \begin{tabular}{|l}
1780 \\
7140
\end{tabular} & $\mid \begin{array}{l}1780 \\
8920\end{array}$ & \begin{tabular}{|r|}
1980 \\
10900 \\
\end{tabular} & \begin{tabular}{|r|}
1790 \\
12690
\end{tabular} \mid & \begin{tabular}{|}
1990 \\
14680
\end{tabular} & $\begin{array}{r}2280 \\
16960\end{array}$ & $\begin{array}{r}2620 \\
19580\end{array}$ & $\begin{array}{r}3040 \\
22620\end{array}$ & $\left|\begin{array}{l}3450 \\
26070\end{array}\right|$ & $\begin{array}{r}3790 \\
29860\end{array}$ & $\begin{array}{l}4120 \\
33980\end{array}$ & $\begin{array}{r}4440 \\
38420\end{array}$ & & & & \\
\hline $\begin{array}{l}\text { COSTS } \\
\text { RESEARCH \& DEVELOPMENT } \\
\text { BEFORE } 78 \\
\text { ANNUAL R\&D } \\
\end{array}$ & $\begin{array}{c}(560.0) \\
40.1 \\
519.9 \\
\end{array}$ & 86.1 & 120.1 & 97.8 & 93.4 & 76.1 & 27.5 & 9.4 & 5.8 & 3.7 & & & & & & & & & & & & & & & $\cdot$ & & & \\
\hline GOVERNMENT OVERHEAD & 195. & & & & & & & & & 13.0 & 13.0 & 13.0 & 13.0 & 13.0 & 13.0 & 13.0 & 13.0 & 13.0 & 13.0 & 13.0 & 13.0 & 13.0 & 13.0 & 13.0 & & & & \\
\hline TRANSPORTATION & & & & & & & & & & & & & & & & & & & & & & & & & & & & \\
\hline $\begin{array}{l}\text { ENCAPSULATION } \\
\text { \#1 CAPITAL } \\
\text { OPS. \& MAINT. } \\
\text { UELUMMISSIONING } \\
\text { \#2 CAPITAL } \\
\text { OPS. \& MAINT. } \\
\text { DECOMMISSIONING }\end{array}$ & $\begin{array}{c}(410.34) \\
287.6 \\
112.74 \\
10.00 \\
n^{1}\end{array}$ & & & & 20.6 & 65.7 & 87.4 & 92.1 & $\begin{array}{l}21.8 \\
.09\end{array}$ & 8.53 & 8.53 & 8.53 & 8.53 & 8.53 & 8.78 & 8.64 & 8.79 & 10.83 & 11.25 & $\begin{array}{l}13.45 \\
20.6\end{array}$ & $\begin{array}{l}15.64 \\
65.7\end{array}$ & $\begin{array}{l}16.07 \\
87.4\end{array}$ & $\begin{array}{l}18.16 \\
92.1\end{array}$ & $\begin{array}{l}18.5 b \\
10.00 \\
21.8\end{array}$ & & & & 287.6 \\
\hline $\begin{array}{l}\text { GEOLOGIC REPOSITORY } \\
\text { \#1 CAPITAL } \\
\text { OPS, \& MAINT. } \\
\text { OECOMMISSIONING } \\
\text { POST OPS. } \\
\text { \#2 CAPITAL } \\
\text { OPS \& MAINT. } \\
\text { OECOMMISSIONING } \\
\text { POST OPS. }\end{array}$ & $\begin{array}{c}(2166.911) \\
596.0 \\
1313.21 \\
78.46 \\
179.241 \\
0^{1}\end{array}$ & 0.35 & 2.68 & 22.68 & $90.77 \mid$ & 146.9 & 132.86 & 104.95 & $\frac{94.81}{.77}$ & 77.2 & 70.14 & 78.4 & 77.84 & 78.08 & 88.54 & 79.18 & $\begin{array}{l}73.95 \\
0.35\end{array}$ & $\begin{array}{l}19.35 \\
2.88\end{array}$ & $\begin{array}{l}96.29 \\
22.68\end{array}$ & 90.77 & $\begin{array}{l}94.20 \\
146.9\end{array}$ & $\mid \begin{array}{l}108.46 \\
132.86\end{array}$ & $\mid \begin{array}{l}104.61 \\
104.95\end{array}$ & $\left|\begin{array}{c}105.84 \\
78.46 \\
179.241 \\
91.81\end{array}\right|$ & & $i$ & & 596. \\
\hline $\begin{array}{l}\text { AFR STORAGE } \\
\text { \#1 CAPITAL } \\
\text { LAND } \\
\text { WORKING CAPITAL } \\
\text { OI'S. \& MAINT. } \\
\text { DECOMMISSIONING } \\
\text { \#2 CAPITAL } \\
\text { LAND } \\
\text { WORKING CAPITAL } \\
\text { OPS. \& MAINT. } \\
\text { DECOMMISSIONING }\end{array}$ & & & & & & & & & & & & & & & & & & & & & & & & & . & & & \\
\hline
\end{tabular}

1 Undiscounted Net - Still Contributes to Discounted Value 
TABLE A-6. UNDISCOUNTED COST MATRIX - CASE i

HIGH FLOW, VENTURE METHODOLOGY

1978 \$ M

\begin{tabular}{|c|c|c|c|c|c|}
\hline Cost Center & Capital & $0: M$ & Trust Funds & Other & Total \\
\hline Geo. Rep. & 596 & 1199 & 514 & & 2309 \\
\hline Encap. & 290 & 201 & 20 & & 511 \\
\hline & 2094 & 160 & 44 & & 2298 \\
\hline Trans & & & & 417 & 417 \\
\hline & & & & 560 & 560 \\
\hline Gov. Overhead & & & & 195 & 195 \\
\hline Total & 2980 & 1560 & 578 & 1172 & 6290 \\
\hline \multicolumn{6}{|c|}{$\begin{array}{c}\text { TABLE A-7. UNDISCOUNTED COST MATRIX - CASE } 2 \\
\text { HIGH FLOW, CAMPAIGN METHODOLOGY } \\
1978 \$ M\end{array}$} \\
\hline Cost Canter & Capital & O\&M & Trust Funds & Other & Total \\
\hline Geo. Rep. & 1073 & 1882 & 580 & & 3475 \\
\hline Encap. & 492 & 309 & 23 & & 824 \\
\hline AFR & 1849 & 136 & 44 & & 2029 \\
\hline Trans. & & & & 417 & 417 \\
\hline$R \& D$ & & & & 560 & 560 \\
\hline Gov. Overhead & & & & 234 & 234 \\
\hline Total & 3354 & 2327 & 647 & 1211 & 7539 \\
\hline
\end{tabular}


TABLE A-8. LNDISCOUNTED COST MATRIX - ILSE 3

LOW FLOW, VENTURE METHODOLOGY

$$
1978 \text { \$ M }
$$

\begin{tabular}{|c|c|c|c|c|c|}
\hline Cost Center & Capital & 0\&M & Trust Funcs & Other & Total \\
\hline Geo. Rep. & 596 & 1645 & 514 & & 275 \\
\hline Encap. & 290 & 234 & 20 & & 544 \\
\hline AFR & & & & & 0 \\
\hline Trans. & & & & & 0 \\
\hline & & & & 560 & 560 \\
\hline Gov. Overhead & & & & 234 & 234 \\
\hline TOTAL & 886 & 1879 & 534 & 794 & 4093 \\
\hline
\end{tabular}


TABLE A-9. UNDISCOUNTED COST MATRIX - CASE 4

LOW FLOW, CAMPAIGN METHODOLOGY

$1978 \$ M$

\begin{tabular}{|c|c|c|c|c|c|}
\hline Cost Center & Capital & $08 M$ & Trust Funds & Other & Total \\
\hline Geo. Rep. & 596 & 1313 & 258 & & 2167 \\
\hline Encap. & 290 & 172 & 10 & & 472 \\
\hline AFR & & & & & 0 \\
\hline Trans. & & & & & 0 \\
\hline & & & & 560 & 560 \\
\hline Gov. Overhead & & & & 195 & 195 \\
\hline TOTAL & 886 & 1485 & 268 & 755 & 3394 \\
\hline
\end{tabular}


TABLE A-10. CONTINGENCY COSTS

1978 \$ M

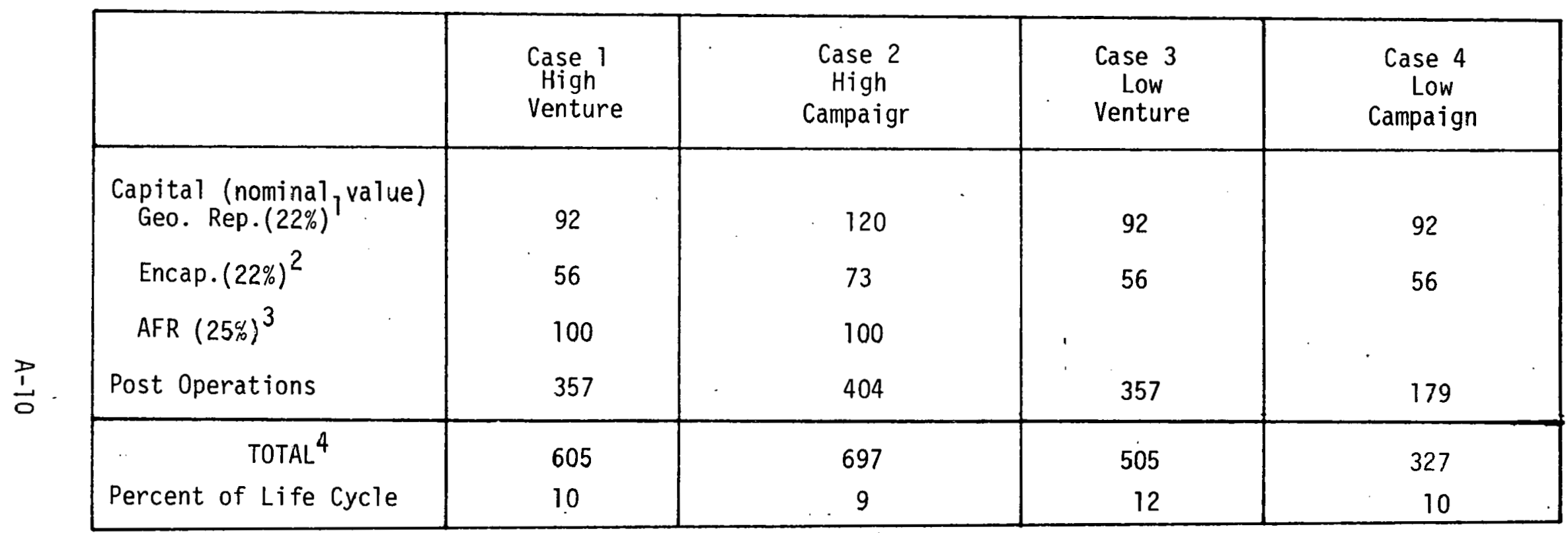

TReference III-4, Base excludes owner's cost

2Assumed 22 percent of Capital excluding Owner's Cost

3 Reference $V-1$, Base excludes Owner's cost

${ }^{4}$ Excludes unspecified Geologic Repository C\&M Contingency josts 
TABLE A-11. PRIVATE AFR CAPITALIZATION COSTS TO THE GOVERIMENT . $12 \%$ DISCOUNTED RETURN AFTER TAXES

\begin{tabular}{|c|c|c|c|}
\hline CASE NO. & AFR NO. & AFR LIFE & ANNUAL CHARGE \\
\hline 1 & 1 & 15 & 73.9 \\
1 & 2 & 13 & 75.7 \\
2 & 1 & 13 & 75.7 \\
2 & 2 & 11 & 78.6 \\
\hline
\end{tabular}




\section{APPENDIX B. DETAILED PRICE RESULTS}

This Appendix presents the breakdown of price results by cost center for dollars per kilogram (Table B-1) and mills per kilowatt hour (Table B-2). Both breakdowas were derived by dividing the final price in proportion to the present value of the expenditure data of the respective cost center. Therefore, there is no relationship between use of a particular facility by a particular shipment of spent fuel and its price. The data shown in Table B-1 is presented graphically in Figure 12-1. 
TABLE B-1. PR_CE RESULTS IN \$/KGU BY COST CENTER

\begin{tabular}{|l|c|c|c|c|}
\hline & $\begin{array}{c}\text { Case 1 } \\
\text { High } \\
\text { Venture }\end{array}$ & $\begin{array}{c}\text { Case 2 } \\
\text { High } \\
\text { Campaign }\end{array}$ & $\begin{array}{c}\text { Case 3 } \\
\text { Low } \\
\text { Venture }\end{array}$ & $\begin{array}{c}\text { Case } \\
\text { Low } \\
\text { Campaign }\end{array}$ \\
\hline Geologic Repository & 52 & 54 & 65 & 74 \\
Encapsulation & 14 & 15 & 17 & 20 \\
AFR & 51 & 38 & 0 & 0 \\
Transportation & 7 & 6 & 0 & 0 \\
R\&D & 23 & 18 & 29 & 35 \\
Government Overhead & 5 & 3 & 5 & 6 \\
\hline \multicolumn{1}{l}{ TOTAL } & 152 & 134 & 116 & 134 \\
\hline
\end{tabular}

TABLE B-2. PRICE RESULTS IN MILLS/KILOWATTT-HOUR BY COST CENTER

\begin{tabular}{|c|c|c|c|c|}
\hline .. & $\begin{array}{l}\text { Case 1 } \\
\text { High } \\
\text { Venture. }\end{array}$ & $\begin{array}{c}\text { Case } 2 \\
\text { High } \\
\text { Campaign }\end{array}$ & $\begin{array}{c}\text { Case } 3 \\
\quad \text { Low } \\
\therefore \text { Venture }\end{array}$ & $\begin{array}{c}\text { Case } 4 \\
\text { Low } \\
\text { Campaign }\end{array}$ \\
\hline Geologic Repository & 245 & .259 & .307 & .344 \\
\hline Encapsulation & .066 & .073 & .079 & .094 \\
\hline AFR & .238 & .168 & 0 & 0 \\
\hline Trzissportation & .034 & .027 & 0 & 0 \\
\hline$R \& D$ & .109 & .083 & .133 & .163 \\
\hline Government Overhead & .021 & .018 & .024 & .026 \\
\hline TOTAL & .713 & .628 & .543 & .627 \\
\hline
\end{tabular}


Appendix C. Formulas for Computation of Spent Fuel Management Price

This appendix contains the formulas, variables, and parameters used in this study to calculate the price of spent fuel management.

\section{General Formulas}

$P_{b} \quad=P V(T C) / P V(Q) \cdot(1)$ where

$\mathrm{P}_{\mathrm{b}} \quad \quad \quad \quad=$ Price per unit of spent fuel computed as of the initial base year, $\mathrm{b}$

$P_{i b} \quad=\left[P V\left(C_{j}\right) / P V(T C)\right] P_{b}$ (2) where

$P_{\text {if }}=$ Component of price attributed to the $i$ - th cost center

$P V(T C)=\sum_{i=1}^{m} \sum_{j=i}^{n_{j}} P V\left(C_{i, j}\right)$ (3) where.

$P V\left(C_{i j}\right)=$ Present value of $j$-th facility in $i$-th cost center

PV(TC) F PV of total cosits

PV(O) $\quad=\sum_{t=y-b}^{S_{z}-b} \frac{Q_{t}}{(1+r)^{t}} \quad t=0,1,2, \ldots$, (4) where

$Q_{t} \quad=$ Units of spent fuel delivered to the governilent in vear $z=b, b+l, \ldots, S_{z}$.

$s_{z} \quad=$ End year of scenario:z.

b $\quad$ = Base year for calculation. Initial base year $=1970$.

$r \quad=$ Discount rate for government revenues.

$=$ Number of facilities in -th cost center.

$=$ Number of cost centers.

Formulas for the PV costs associated with tire cost centers follow. 


\section{Formulas for AFR Costs $\left(C_{7}\right)$}

$\operatorname{PV}\left(c_{1 j}\right)=\sum_{t=y-b}^{S_{z}-b} \frac{c_{1 j t}}{(1+d)^{t}}+\frac{T_{1}}{(1+d)^{S}{ }^{-b}} \quad(1-1)$ where

$\mathrm{TR}_{1} \quad=$ Trust fund for decommissioning $=\sum_{t=0}^{2} \frac{\mathrm{DC}}{(1+d)^{t}}$. where

$D C_{1 t}=$ Annual decommissiong costs for an AFR :

d $\quad=$ Discount rate for government costs

$c_{1 j t}=$ Cost of $j-$ th AFR in $t$-th year with

$C_{7 j i}=O M_{1 j i}+\operatorname{FCR}\left(k, N_{1 j}, M\right) P V\left(K_{1 j}\right)+\operatorname{CRF}\left(k, N_{7 j}\right)\left[\frac{P V\left(L_{1 j}\right)+M i}{(j-i)}\right]\left[1-\frac{1}{(1+k)^{N j}}\right]$ (1-2) where

${ }^{014} 7 j t=084$ costs for $j$-th AFR in $t$-th year. Note Oell is not defined to include property taxes and insurance, but it may be redefined to include these ad valorem charges if the $F C R$ is defined to exclude theirl.

$\mathrm{FCR}\left(\mathrm{K}, \mathrm{H}_{7 j}, M\right)=$ Fixed Capital Recovery Factonr (Fnmulated below).

$K_{1 j t}=\dot{P} 1$ ant and capital equipment costs expended in year $t$ for the $j$-ti AFR excludirig land and land rights.

$$
P Y^{\prime}\left(k_{1 j}\right)=\sum_{t=y-b}^{B_{2 j}-b} \frac{k_{l j t}}{(1+k)^{t-B_{2 j}+b}} \quad \text { for } y=b, b+1, \ldots, B_{1 j} \text {. }
$$

$k=$ After tax discounted return expected by private owner(s) of the ARFs:

$N_{1 j}=$ Operating life of $j$-th AFR equail to $E_{7 j}-B_{7 j}+1$, where."

$E_{j_{j}}=$ Last year in which fucl elements are ever stored in $j$-th. AFR or in which 0il $1 j$, whichever cones last. Note, $E_{7, j}$ assumed $\leq S_{z}$

$B_{1 j !}=$ First jear of beneficial use of $j$-th AFR.

$M=$ Mode of depreciation $=1,2$, or 3 corresponding to straight-1ine (SL), sum of years digits (SYO) or double-cieclining balance (DDB) depreciation. 


$$
\operatorname{CRF}\left(K, N_{7 j}\right)=\frac{k(7+k)^{N_{1 j}}}{(1+k)^{N_{1 j}}}
$$

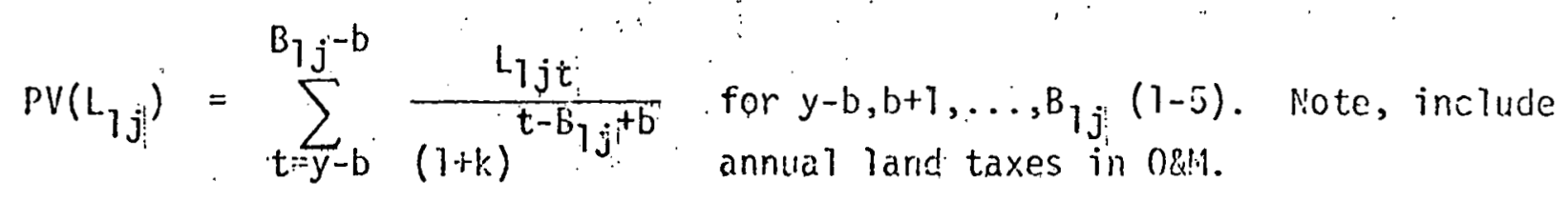

$W C_{1 j}=\underset{\left.B_{7 j}\right)}{\text { Working capital for } j \text {-th AFR (assumed to be recognized in year }}$

$L_{1 j t}=$ Cost of land and larid rights incurred in $t$-th year for $j$-th AFR.

$\tau=$ Effective federal and local income tax rate borne by private Afr.

$F C R\left(K, N_{1 j: P} P^{M}\right)=\frac{\operatorname{CRF}\left(k, N_{1 j}\right)}{(1-\tau)}\left[1-\alpha-\tau D(i i)+\frac{(1-\tau)\left(\beta_{1}+\beta_{2}\right)}{\operatorname{CRF}\left(K, N_{i j}\right)}\right] \quad(T-\epsilon)$ where

$\alpha=$ Effective income tax credit (ITC) adjusted for equipinent content of AFR.

$D(11)=$ Depreciation factor for it-th mode of depreciation.

$D(1)=\left[N_{1 j} C R F\left(K, \dot{N}_{1 j}\right)\right]^{-1}$

$D(2)=2\left[N_{1 j !}\left(N_{1 j}+J\right) k\right]^{-1} \cdot\left[H_{2 j}-\frac{1}{\operatorname{CRF}\left(k, N_{1 j}\right)}\right]$

$D(3)=\left(2 / N_{1 j}\right)(1+k)\left[k+2 / N_{1 j}\right]^{-1}$

$B_{1}=$ Property tax rate (Decimal Fraction of value of plant and equipiant).

$B_{2}=$ Insurance rate (Decimal fraction of value of plant and equipment). 
3. Formulas for Encapsulation Facility Costs $\left(C_{3}\right)$

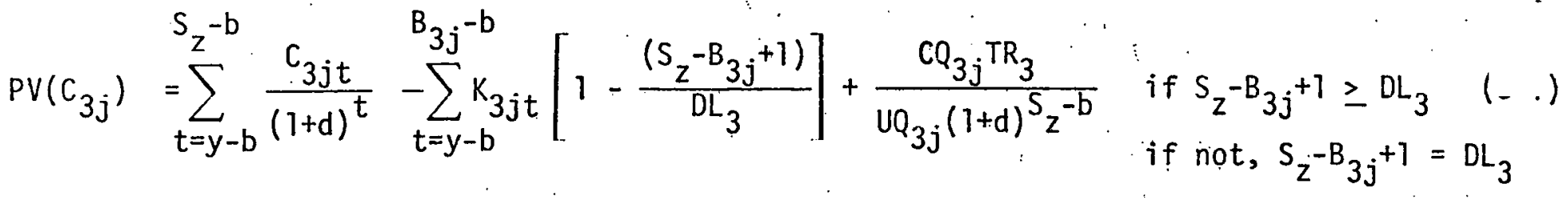

$$
\begin{aligned}
& \mathrm{C}_{3 j t}=\mathrm{OM}_{3 j t}+\mathrm{K}_{3 j t} \text {, where } \\
& \mathrm{OM}_{3 \mathrm{jt}}=\mathrm{O \& M} \text { costs for } \mathrm{j} \text {-th encapsulation site in } t \text {-th year. } \\
& K_{3 j t}=\text { Plant and Capital equipment costs expended in the } t \text {-th year for } \\
& \text { the } j \text {-th encapsulation facility. } \\
& \mathrm{CQ}_{3 j}=\text { Cumulative spent-fuel stored in } j \text {-th site at end of scenario life. } \\
& U_{3 j}=\text { Ultimate capacity for spent fuel in the } j \text {-th site if fulty utilized } \\
& \text { under scenario rules. } \\
& \mathrm{TR}_{3}=\text { Trust Fund for decommissioning }=\sum_{t=0}^{6} \frac{D C_{3 t}}{(1+d)^{t}}, \text { where } \\
& \mathrm{DC}_{3} \quad=\text { Annual decommissioning costs for encapsulation sites. } \\
& B_{3 j}=\text { First year of beneficial use of } j \text {-th encapsulation site: } \\
& \mathrm{DL}_{3}=\text { Designated depreciation life of encapsulation site. }
\end{aligned}
$$




$$
\begin{aligned}
& P V\left(C_{5 j}\right)=\sum_{t=y-b}^{S_{-b}^{-b}} \frac{C_{5 j t}}{(1+d)^{t}}-\frac{\sum_{t=y-b}^{B_{5 j}-b}\left[K_{5 j t}\left[\frac{\left(S_{z^{-B}}-B_{j}+7\right)}{D L_{5}}\right]\right.}{(1+d)^{S_{z}-b}}+\frac{C_{5 j}}{U Q_{5 j}}\left[\frac{T R_{5}+A}{(1+d)^{S} z^{-b}}\right] \\
& \text { if } \mathrm{S}_{z}-\mathrm{B}_{5 \mathrm{j}} \mathrm{j}^{+]} \geq \mathrm{DL}_{5} \\
& \text { if not, } \mathrm{S}_{Z}-\mathrm{B}_{5 j}+1=\mathrm{DL}_{5}
\end{aligned}
$$

$\mathrm{C}_{5 j \mathrm{t}}=\mathrm{OM}_{5 j \mathrm{t}}+\mathrm{K}_{5 j \mathrm{t}}$ where $\begin{aligned}{ }^{0} M_{5 j t}= & 0 \& M \text { costs for } j-\text { th geologic site (excluding encapsulation) } \\ & \text { in } t \text {-th year. }\end{aligned}$

$K_{5 j t}=$ Plant and capital equipment costs (ex., encapsulation) expended in $t$-th year for the $j$-th geologic site including land and land rights.

$\mathrm{CQ}_{5} \mathrm{j}^{\mathrm{j}}=\begin{aligned} & \text { Cumulative spent-fuel stored in } j \text {-th site at end of scenario } \\ & \text { life. }\end{aligned}$

$U_{5 j}=$ Ultimate capacity for spent fuel in the $j$-th site if fully utilized under scenario rules.

$\mathrm{TR}_{5}$. Trust Fund for decommissioning $=\sum_{t=0}^{6} \frac{\mathrm{DC}}{(1+d)^{t}}$ where

$D C_{5 t}:=$ Annual decommissioning costs for geological site. $\begin{aligned} B_{5 j}= & \text { First year of beneficial use (ex., encapsulation) of } j \text {-th } \\ & \text { geologic site. }\end{aligned}$

$\mathrm{DL}_{5}=$ Designated depreciation life for geologic site.

A = Value of annuity purchased in last year of Scenario which will provide required annual funding for post operational activities from year $\mathrm{S}_{\mathrm{Z}}+1$ onward.

A $\quad=a / i$ where

a = Annual cost of post operational activities.

$i \quad=$ Rate of annuity interest. 
6. Formulas for Government Transportation Costs $\left(C_{6}\right)$

$$
\operatorname{PV}\left(C_{6}\right)=\sum_{t=y-b}^{S_{z}-b} \frac{c_{6 t}}{(1+d)^{t}}
$$

$(6-1) \quad$ where

$$
\begin{aligned}
c_{6 t_{1}}= & \begin{array}{l}
\text { Cost to government for transportation in the } t \text {-th year. Other } \\
\text { notation as before. }
\end{array}
\end{aligned}
$$

Note the above formula would also apply to government overhead costs $\left(c_{8}\right)$.

Ci 


\section{Formulas for R\&D Costs $\left(C_{7}\right)$}

$$
\begin{aligned}
& P V\left(c_{7}\right)=\sum_{t=y-b}^{S_{7}-b} \frac{c_{7 t}}{(1+d)^{t}}+c_{7 \bar{b}}(7-1) \text { for } y=h, b+7, \ldots, s_{z} \text {, wherc } \\
& C_{7 \bar{b}}=\text { R\&D costs chorgeable to the progran incurred } \\
& \text { prior to the initial base year of } 1978 .
\end{aligned}
$$

All other notation as above. 
Table C-1. Variables

\begin{tabular}{|c|c|c|c|}
\hline Variable. & Symbol & $\mathrm{I} / 0$ & Units \\
\hline System price (baseyear b) & $\mathrm{P}_{\mathrm{b}}$ & 0 & \$Million (1978)/tonne \\
\hline Price components & $P_{i b}$ & 0 & \$Million (1978)/tonne \\
\hline PV total costs & $\mathrm{PV}(\mathrm{TC})$ & 0 & 1978\$, Millions \\
\hline $\begin{array}{l}\text { PV cost of } j \text {-th facility in } \\
i-\text { th cost center }\end{array}$ & $P C\left(C_{j}\right)$ & 0 & $.1978 \$$, litilions \\
\hline P.V cost of $i-t h$ cost center & $\operatorname{PV}\left(C_{j}\right)$ & 0 & 1978, Millions \\
\hline $\begin{array}{c}\text { Number of facilities in } n_{\mathbf{i}} \\
j-\text { th renst. renter }\end{array}$ & $n_{i}$ & I. & 1 or 2 digits \\
\hline Number of cost centers & $\mathrm{m}$ & I & 1 or 2 digits \\
\hline Quantity shipped in $t$-th year & $Q_{t}$ & I & Tonnes per year \\
\hline End year of scenario $z$ & $S_{z}$ & I & 4. digits \\
\hline Base year & b & I & 4 digits \\
\hline AFR annual $0 \& M$ costs* & $\mathrm{OM}_{1 j t}$ & I & 1978\$, Millions \\
\hline $\begin{array}{l}\text { AFR annual capital costs } \\
\text { (ex.. land) }\end{array}$ & $k_{1 j t}$ & I & 1978\$, Millions \\
\hline AFR annual land costs & $L_{1 j t}$ & I & 1978\$, Millions \\
\hline AFR working capital & $W C_{1 j}$ & I & 1978\$, Millions \\
\hline AFR operating lifa & $N_{1 j}$ & I. & Years \\
\hline$A F R$ end year & $E_{1 j}$ & I & 4 digits \\
\hline AFR beneficial year & $B_{1 j}$ & I & 4 digits \\
\hline Annual decommissioning costs & $D C_{1 t}$ & $I$ & 1978\$, Millions \\
\hline $\begin{array}{l}\text { Encapsulation annual } 08 M \\
\text { costs }\end{array}$ & $\mathrm{OM}_{3 j \mathrm{t}}$ & I & 1978 $\$$, Millions \\
\hline $\begin{array}{l}\text { Encapsulation annual capital } \\
\text { costs }\end{array}$ & $k_{3 j t}$ & I & 1978\$, Hillions \\
\hline $\begin{array}{l}\text { Encâpsulation beneficial } \\
\text { year }\end{array}$ & $B_{3 j}$ & $\mathrm{I}$ & 4 digits \\
\hline
\end{tabular}


Table C-1, Variables (Continued)

\begin{tabular}{|c|c|c|c|}
\hline Variable & Symbol: & $\mathrm{I} / 0$ & Units \\
\hline Geologic annual $0 \& M$ costs & $\mathrm{OM}_{5 j \mathrm{t}}$ & I & 1978\$, Millions \\
\hline $\begin{array}{l}\text { Geologic annual decommis- } \\
\text { sioning costs }\end{array}$ & $\mathrm{DC}_{5 j t}$ & I & 1978\$, Millions \\
\hline Geologic annual capital costs & $k_{5 j t}:$ & I & 1978\$, Millions \\
\hline Annual surveillance costs & a $\quad \because$ & I & 1978\$, Millions \\
\hline Geologic beneficial year & $B_{5 j}$ & I & 4 digits \\
\hline Annual transportation costs & $c_{6 t}$ & I & 1978\$, Millions \\
\hline Annual R\&D charges & $c_{7 t}$ & $I^{\prime}$ & 1978\$, Millions \\
\hline R\&D charges before 1978 & $c_{7 \bar{b}}$ & I & 1978\$, Millions \\
\hline Government overhead costs & $\mathrm{C}_{8 \mathrm{t}}$ & $\mathrm{I}$ & $\begin{array}{l}1978 \$ \text {, Millions } \\
\therefore .\end{array}$ \\
\hline
\end{tabular}


Table C-2. Parameters

\begin{tabular}{|c|c|c|}
\hline Parameter & Symbol & Default Value \\
\hline Revenue discount rate & $r$ & 0.065 \\
\hline Cost discount rate ". & d & 0.065 \\
\hline Private return rate & $\mathrm{k}$ & 0.12 \\
\hline Effective income tax rate & $\tau$ & 0.50 \\
\hline $\begin{array}{l}\text { Effective income tax } \\
\text { credit }\end{array}$ & $\alpha$ & 0.06 . \\
\hline Property tax rate (AFR) & $\beta_{1}$ & .015 \\
\hline Insurance rate (AFR) & $\beta_{2}$ & .005 \\
\hline Depreciation mode & M & 3 \\
\hline $\begin{array}{l}\text { Depreciation life of } \\
\text { encapsulation }\end{array}$ & $\mathrm{DL}_{3}$ & 10 \\
\hline $\begin{array}{l}\text { Depreciation life of } \\
\text { geologic site }\end{array}$ & $\ldots L_{5}$ & 10 \\
\hline Annuity interest & $i$ & 0.065 \\
\hline
\end{tabular}


Appendix D. Proof of Equivalence of Capital Recognition Procedure to Interest/Depreciation Procedure for Government Capital Costs

The notation used is as follows:

$C=$ Government capital charge in a particular year.

$i=$ Government cost discount and imputed interest rate.

$w=$ Number of years (or other unit) between time capital charge incurred and first beneficial use of capital.

$n=$ Number of years of beneficial use of capital.

$t=$ Time index.

If the simple procedure is used, $C$ will be recognized in the year incurred. Without loss of generality, recognition can be assumed to occur in the base year, so the cost to the government would simply be $C$.

On the other hand, the recognition procedure might be:

- Recognize oniy interest charges on capital (C) until the first year of beneficial use.

- When beneficial use starts, recognize:

- Annual depreciation charges (assumed to be based on the straight line mode), and

- Interest charges on undepreciated capital.

The PV of the above charges relative to the year of the investment (i.e., the base year) is:

$$
i c \sum_{t=0}^{w-1} \frac{1}{(1+i)^{t+1}}+\frac{1}{(1+i)^{w}}\left[c / n \sum_{t=1}^{n} \frac{1}{(1+i)^{t}}+i c \sum_{t=1}^{n-1} \frac{(1-t / n)}{(1+i)^{l+1}}\right]
$$

Note that costs are assumed to occur at the beginning of a year while interest is not due until the end of the year.

The first term of the above expression represents the PV of interest during construction, while the second term is the PV of depreciation charges and interest on undepreciated capita 1. 
To evaluate the first term, substitute:

$$
x=\frac{1}{1+i} \text { and } 1-x=\frac{i}{1+i} \text {, or }
$$

$P V\left(\right.$ Interest during construction) $=c\left[(1-x) \sum_{t=0}^{W-1} x^{t}\right]=C\left[\frac{(1-x)\left(1-x^{W}\right)}{(1-x)}\right]=c-C x^{w}$.

After the $x$-substitution, the discount factor which multiplies the bracketed variables is simply $x^{W}$. Therefore, the PV on depreciation charges and interest on undepreciated capital is $x^{W}$ times the variables in the bracket.

Using the notation from the previous page, the PV of depreciation and interest charges during beneficial use can be expressed as $x^{W}$ times the following:

$c / n \sum_{t=1}^{n} \frac{1}{(1+i)^{t}}+i c \sum_{t=0}^{n-1} \frac{(1-t / n)}{(1+i)^{t+1}}=c\left[1 / n \sum_{t=1}^{n} \frac{1}{(1+i)^{t}}+\frac{i}{1+i} \sum_{t=0}^{n-1} \frac{1}{(1+i)^{t}}-\frac{i}{n(1+i)} \sum_{t=0}^{n-1} \frac{t}{(1+i)^{t}}\right]$

Substituting $x=\frac{1}{1+i}$, we have:

$c\left[1 / i \sum_{t=1}^{n} x^{t}+(1-x) \sum_{t=0}^{n-1} x^{t}-\frac{(1-x)}{n} \sum_{t=0}^{n-1} i x^{t}\right]=c\left[1 / n \sum_{t=1}^{n} x^{t}+(1-x) \sum_{t=0}^{n-1} x^{t}-\frac{x(1-x)}{n} \sum_{t=0}^{n-1} t x^{t-1}\right]$

$$
=c\left[1 / n \sum_{t=1}^{n} x^{t}+(1-x)_{t=0}^{n-1} t=\frac{x(1-x)}{n} \cdot \frac{d \sum_{t=0}^{n-1} t}{d x} \sum_{t=0}^{n}\right]
$$


Using the geometric sum forliuta, the PV of depreciation and interest charges are:

$$
\begin{aligned}
& c\left[\frac{x}{n}\left(\frac{1-x^{n}}{1-x}\right)+\frac{1-x}{1}\left(\frac{1-x^{n}}{1-x}\right)-\frac{x(1-x)}{n} \frac{d}{d x}\left(\frac{1-x^{n}}{1-x}\right)\right] \text { or } \\
& c\left\{x / n\left(\frac{1-x^{n}}{1-x}\right)+\frac{1-x^{n}}{1}-\frac{x}{n}\left[\frac{(1-x)\left(-n x^{n-1}\right)-\left(1-x^{n}\right)(-1)}{(1-x)^{2}}\right]\right\} \text { or } \\
& c\left\{\frac{x}{n(1-x)}\left[\left(1-x^{n}\right)+(1-x) n x^{n-1}-\left(1-x^{n}\right)\right]+1-x^{n}\right\} \text { or } \\
& c\left\{\frac{x}{n\left(\frac{x}{1-x}\right)}\left[(1-x) n x^{n-1}\right]+1 \cdot x^{n}\right\}=c\left[\frac{x n x^{n-1}}{n}+1-x^{n}\right]=c
\end{aligned}
$$

Accordingly, when $C$ is discounted to the base year by the factor $x^{W}$, we have $C-C x$ ( $P V$ of interest during construction) $+x^{W} C$ (PV of depreciation and interest on undepreciated capital) which equals $C$.

Note that the above proof depends on:

- Absence of income taxes.

- Use of same value for the discount and interest rate. 